\section{To: (Receiving Organization)}

Distribution

5. Proj./Prog./Dept./Div.:

Tank Waste Remediation

Systems (TWRS)

8. Originator Remarks:

For approval and release.
Tank Waste Retrieval \& Disposal

6. Cog. Engr.:

S. H. Rifuey 0os 1/6/98 K.N. JordA
3. from: (Originating organization)

4. Related EDT No.:

$\mathrm{N} / \mathrm{A}$

7. Purchase Order No.:

$\mathrm{N} / \mathrm{A}$

9. Equip./Component No.:

N/A

10. System/Bldg./Facility:

N/A

11. Receiver Remarks: 11A Design Baseline Document? $\square_{\text {Yes }} \boldsymbol{\bigotimes}_{\text {No }}$
12. Major Assm. Dwg. No.:

$$
\text { N/A }
$$

13. Permit/Permit Application No.: N/A

14. Required Response Date: $1 / 5 / 98$

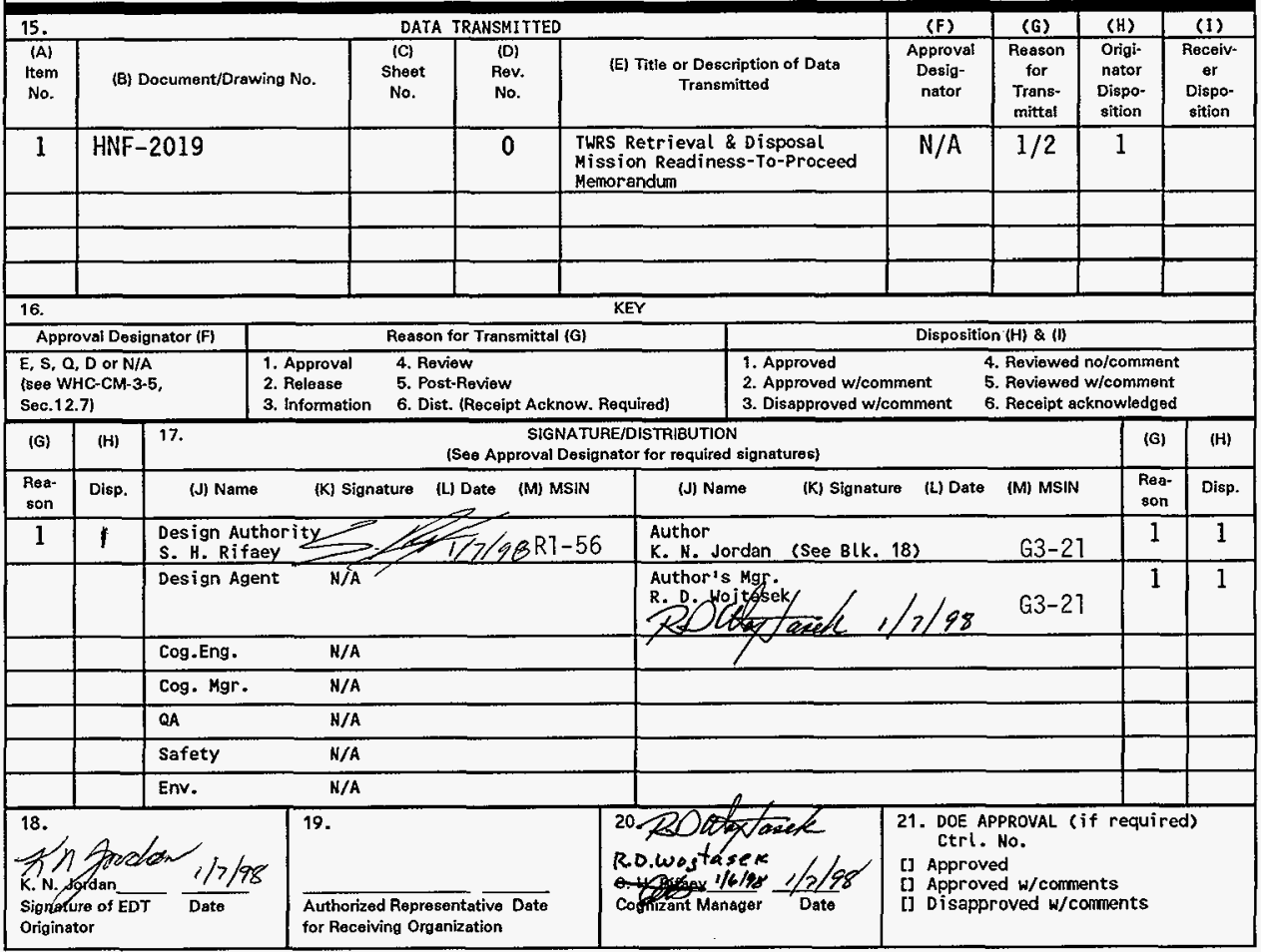




\title{
Tank Waste Remediation System Retrieval and Disposal Mission Readiness-to-Proceed Memorandum
}

\author{
K.N. Jordan \\ Lockheed Martin Hanford Company, Richland, WA 99352 \\ U.S. Department of Energy Contract DE-AC06-96RL.13200 \\ EDT/ECN: 622750 \\ Org Code: 72260 \\ UC: 2030 \\ Charge Code: D215P \\ B\&R Code: EW3130010 Tota7 Pages: 114
}

Key Words:- TWRS, Retrieval and Disposal Mission, Readiness-to-Proceed Memorandum

Abstract: This memorandum provides a summary of PHMC team work scope for the Phase 1 TWRS Retrieval and Disposal Mission, a declaration of readiness-to-proceed, a summary of the PHMC team readiness evaluation process, summary results of a structured independent appraisal and financial analysis including information associated with assumptions, risks, and recommendations and, a summary of program plans for the PHMC team's component of the Phase 1 Mission.

TRADEMARK DISCLAIMER. Reference herein to any specific commercial product, process, or service by trade name, trademark, manufacturer, or otherwise, does not necessarily constitute or imply its endorsement, recommendation, or favoring by the United states Goverment or any agency thereof or its contractors or subcontractors.

Printed in the United States of America. To obtain copies of this document, contact: Document Control Services, P.0. Box 950, Mailstop H6-08, Richland HA 99352, Phone (509) 372-2420; Fax (509) 376-4989.
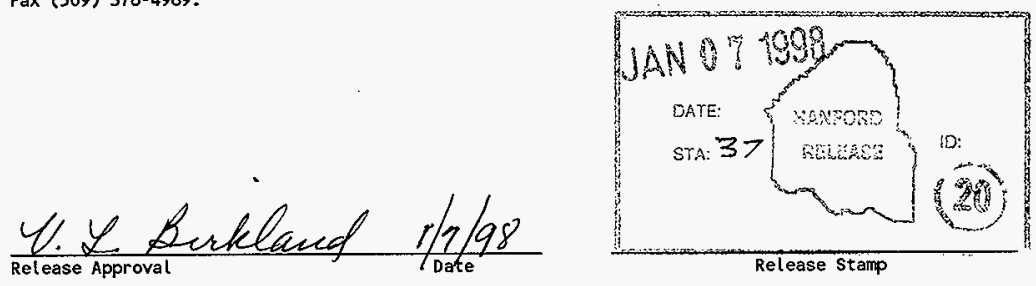
HNF-2019

Rev. 510

\section{Tank Waste Remediation System Retrieval and Disposal Mission Readiness-to-Proceed Memorandum}

H. L. Boston

K. N. Jordan

Lockheed Martin Hanford Corporation.

Date Published

January 1998

Prepared by Lockheed Martin Hanford Corporation Richland, Washington

Prepared for the U.S. Department of Energy

T. Fluor Daniel Hanford, Inc.

P.O. Box 1000

Hanford Management and Integration Contractor for the

U.S. Department of Energy under Contract DE-AC-0696-RL13200 
HNF-2019 Rev 0

LEGAL DISCLAIMER

This report was prepared as an account of work sponsored by an agency of the United States Government. Neither the United States Government nor any agency thereof, nor any of their employees, nor any of their contractors,

subcontractors or their employees, makes any warranty, express or implied, or assumes any legal liability or responsibility for the accuracy, completeness, or any third party's use or the results of such use of any information, apparatus, product, or process disclosed, or represents that its use would not infringe privately owned rights.

Reference herein to any specific commercial product, process, or service by trade name, trademark, manufacturer, or otherwise, does not necessarily constitute or imply its endorsement, recommendation, or favoring by the United States Government or any agency thereof or its contractors or subcontractors. The views and opinions of authors expressed herein do not necessarily state or reflect those of the United States Government or any agency thereof.

This report has been reproduced from the best available copy.

Available in paper copy and microfiche.

Available to the U.S. Department of Energy and its contractors from

U.S. Department of Energy

Office of Scientific and Technical Information (OSTI)

P.O. Box 62

Oak Ridge, TN 37831

(615) 576.8401

Available to the public from the U.S. Department of Commerce

National Technical information Service (NTIS)

5285 Port Royal Road

Springfield, VA 22161

(703) $487-4650$

Printed in the United States of America

DISCLM-1.CHP (8-95) 
HNF-2019 Rev 0

This page intentionally left blank. 
HNF-2019 Rev 0

Document Title: Tank Waste Remediation System Retrieval and Disposal Mission Readiness-to-Proceed Memorandum

Approved by:

Iz ttall

L.E. Hall, President and General Manager

Tank Waste Remediation System Project

Lockheed Martin Hanford Corporation

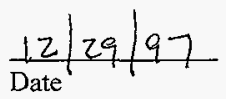

Date

A. M. Umek, Project Director

Tank Waste Remediation System Project

Fluor Daniel Hanford, Inc. 
This page intentionally left blank. 


\section{EXECUTIVE SUMMARY}

The U.S. Department of Energy (DOE) has developed a two-phased plan for retrieving, immobilizing, and dispasing of approximately 54 million gallons of high-level radioactive waste stored in 177 underground storage tanks at the DOE Hanford Site in southeastern Washington State. This work is part of the Tank Waste Remediation System (TWRS) Project established by DOE for the disposal of Hanford tank waste. The tank waste poses substantial potential risk to health and the environment. There is an urgency to moving forward with the clean-up process. As part of the clean-up plan, private contractors will build and operate waste immobilization facilities. Under this "privatization" approach, the DOE will award contracts competitively bid for the waste immobilization services. The first phase of waste treatment is scheduled to begin in 2002 and to be completed by 2011. Phase 1 will result in the treatment (immobilization) of up to 13 percent of the tank waste.

One of the prerequisites for DOE's authorization to proceed with private contracts is the affirmation that the Hanford Management and Integration (M\&l) Contractor, Fluor Daniel. Hanford ( $F D H)$, and the key subcontractors that comprise the Project Hanford Management Contract (PHMC) team are ready to proceed with their component of the clean-up mission per the DOE plan. The PHMC team, and specifically the contractor assigned responsibility for the TWRS Project, Lockheed Martin Hanford Corporation (LMHC), must be able to (1) deliver tank waste as feed for the immobilization facilities, (2) receive immobilized tank waste products for storage and disposal, (3) receive secondary wastes and specified by-products for treatment, and (4) provide infrastructure support for the private facilities. The PHMC team's portion of the TWRS Project is identified as the TWRS Retrieval and Disposal Mission. The DOE requested 
that the PHMC team prepare documentation of readiness-to-proceed with the Phase I Mission consistent with the terms of contracts between DOE and private contractors for the waste treatment (immobilization) component of the mission.'

This memorandum provides:

(I) A summary of PHMC team workscope for the Phase I TWRS Retrieval and Disposal Mission,

(2) A declaration of readiness-to-proceed,

(3) A summary of the PHMC team readiness evaluation process,

(4) Summary results of a structured independent appraisal and financial analysis including information associated with assumptions, risks, and recommendations and,

(5) A summary of program plans for the PHMC team's component of the Phase 1 Mission.

Appendices, attachments, and enclosures include:

(1) A 36 Item Checklist provided as guidance by DOE with updated status,

(2) A Critical Risk List,

(3) A Mission Analysis Report,

(4) A Program Plan,

(5) An Initial Updated Baseline Summary,

'Taylor, W.J., 1997, Contract Number DE-ACO6-96RL13200, Tank Waste Remediation System (TWRS) Privatization - Hanford Contractors Readiness-to-Proceed, (letter 97-WDD-129 to H. J. Hatch, Fluor Daniel Hanford, Inc., August 8), U.S. Department of Energy, Richland Operations Office, Richland, Washington. 
(6) A Guidance and Requirements to Deliverables Crosswalk,

(7) A Key Enabling Assumptions List and,

(8) A Financial Analysis Report.

To summarize, an assessment of the PHMC team's ability to proceed with the Phase 1 TWRS Retrieval and Disposal Mission concluded that: an overall systems approach has been applied to develop the plans to support the mission, and that management and technical plans satisfy the requirements for the Phase 1 Mission and are consistent with the schedule prescribed by DOE. Systems, resources, and infrastructure needed to support the mission are understood. Required systems are either in place, or plans exist to assure they are available when needed. The M\&I Contractor and the TWRS Project contractor have demonstrated a robust systems engineering culture, the necessary management systems, and the capability to execute the TWRS Retrieval and Disposal Mission. Requirements and lines of communication are clearly established and configuration is rigorously managed.

The TWRS Retrieval and Disposal Mission requires upgrades and modifications to facilities; however, the Phase 1 Mission is largely an extension of current operations, and requires no technology breakthroughs or first of a kind processes. The assumptions that underlie the plans are known and are being managed. Risks (technical, environmental, safety, health, cost, schedule, programmatic) associated with the plans, equipment, and activities have been evaluated; mitigation actions have been incorporated into plans as appropriate; and the residual risks are being managed. The management approach has drawn on successes and lessons learned to establish the process, culture, and discipline that support safe and successful mission execution. 
A Financial Analysis of the PHMC team's Phase I Mission Updated Baseline demonstrates that overall costs are within 10 percent of target funding levels and are presumed to be manageable within overall Environmental Management and/or U.S. Department of Energy, Richland Operations Office funding levels. The necessary systems, personnel, and equipment are ready to proceed with the TWRS Project Phase 1 Mission. 


\section{CONTENTS}

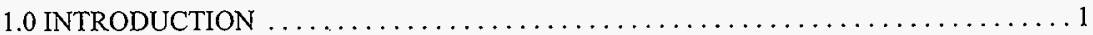

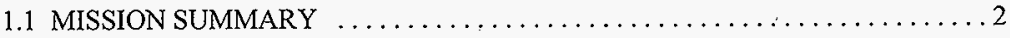

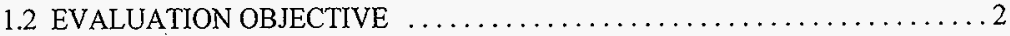

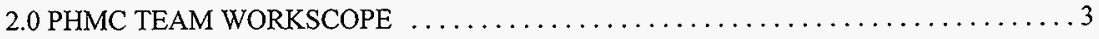

3.0 DECLARATION OF READINESS TO PROCEED $\ldots \ldots \ldots \ldots \ldots \ldots \ldots \ldots$

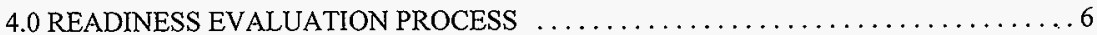

4.1 REQUIREMENTS, GUIDANCE, AND CRITERIA .................. 6

4.2 MANAGEMENT PLANS AND PROGRAM BASELINE $\ldots \ldots \ldots \ldots \ldots \ldots .9$

4.2.1 Mission Definition and Direction $\ldots \ldots \ldots \ldots \ldots \ldots \ldots \ldots \ldots$

4.2.2 Management Plans and Procedures . . . . . . . . . . . . . . . . 9

4.2 .3 Integrated Baseline . . . . . . . . . . . . . . . . . . . . . 11

4.3 ANALYSIS PROCESSES AND PRODUCTS $\ldots \ldots \ldots \ldots \ldots \ldots \ldots \ldots \ldots$

4.3.1 Guidance and Requirements to Deliverables Crosswalk ...........13

4.3.2 Statused 36 Item Checklist . . . . . . . . . . . . . . . . . . . 13

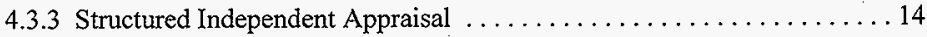

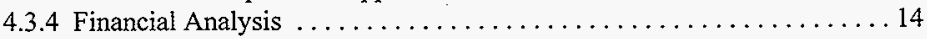

4.3.5 Key Assumptions and Critical Risks . . . . . . . . . . . . . 15

5.0 SUMMARY OF RETRIEVAL AND DISPOSAL MISSION PLANNING . . . . . . . 15

5.1 BACKGROUND AND EVOLUTION OF THE TWRS RETRIEVAL AND

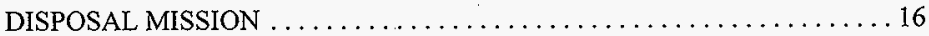

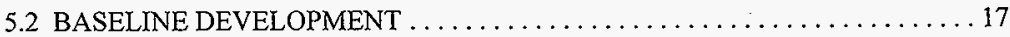

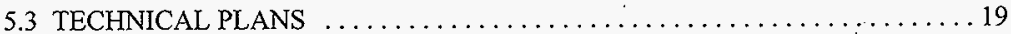

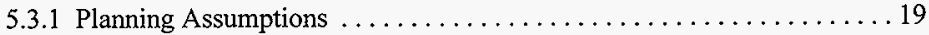

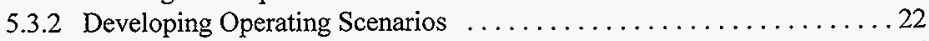

5.3.3 Infrastructure Support to Private Contractors and Other Interfacess . . . . . 36

5.3.4 Summary of Technical Plans . . . . . . . . . . . . . . . . . . . 37

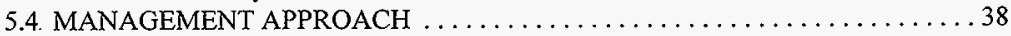

5.5 ASSUMPTIONS, RISKS, AND RECOMMENDATIONS $\ldots \ldots \ldots \ldots \ldots \ldots 40$

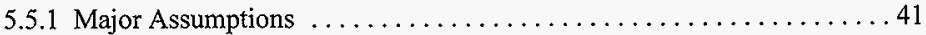

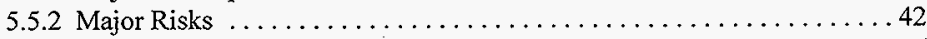

5.5.3 Recommendations for Reducing Risk and Cost $\ldots \ldots \ldots \ldots \ldots \ldots 43$

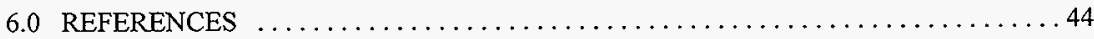




\section{LIST OF FIGURES}

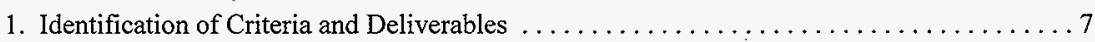

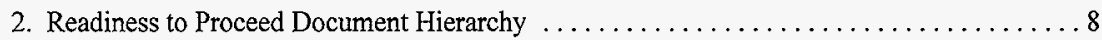

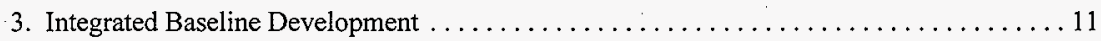

4. Top-Level Summary of Technical Basis for Operations $\ldots \ldots \ldots \ldots \ldots \ldots \ldots$

5. Examples of Feed Delivery Configurations. . . . . . . . . . . . . . . . . 27

6a. Top-Level Tank Waste Remediation System Schedule. . . . . . . . . . . . . 28

6b. Top-Level Tank Waste Remediation System Schedule . . . . . . . . . . . . . . . . 29

7. Immobilized Low-Activity Waste Storage and Disposal $\ldots \ldots \ldots \ldots \ldots \ldots \ldots \ldots \ldots \ldots \ldots \ldots$

8. Immobilized High-Level Waste Exploratory Analysis $\ldots \ldots \ldots \ldots \ldots \ldots \ldots \ldots \ldots$

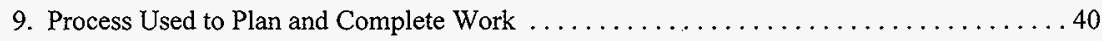

\section{LIST OF TABLES}

1. Major Tank Waste Remediation System Milestones $\ldots \ldots \ldots \ldots \ldots \ldots \ldots \ldots \ldots$

2. Waste Feed Envelopes Summary.............................. 20

3. Major Requirements and Assumptions That Influence the Operating Scenario. . . . . . . . . . . . . . . . . . . . . . . . . . 20

4. Comparison of Low-Activity Waste and High-Level Waste Feed Quantities with Contract

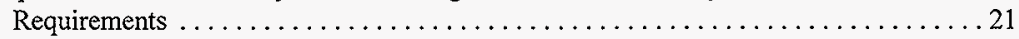

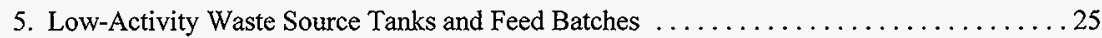

6. High-Level Waste Source Tanks and Feed Batches $\ldots \ldots \ldots \ldots \ldots \ldots \ldots \ldots$

7. Interface Control Documents Between TWRS Retrieval and Disposal Program and Private Contractors . . . . . . . . . . . . . . . . . . . . . . . . . . 37 


\section{LIST OF TERMS}

$\begin{array}{ll}\text { BIO } & \text { Basis for Interim Operation } \\ \text { DOE } & \text { U.S. Department of Energy } \\ \text { DST } & \text { double-shell tank } \\ \text { Ecology } & \text { Washington State Department of Ecology } \\ \text { EIS } & \text { Environmental Impact Statement } \\ \text { EPA } & \text { U.S. Environmental Protection Agency } \\ \text { FDH } & \text { Fluor Daniel Hanford, Inc. } \\ \text { FY } & \text { fiscal year } \\ \text { HLW } & \text { high-level waste } \\ \text { ICD } & \text { interface control document } \\ \text { IHLW } & \text { immobilized high-level waste } \\ \text { ILAW } & \text { immobilized low-activity waste } \\ \text { LAW } & \text { low-activity waste } \\ \text { LMHC } & \text { Lockheed Martin Hanford Corporation } \\ \text { M\&I } & \text { Management and Integration } \\ \text { MT } & \text { metric ton } \\ \text { PHMC } & \text { Project Hanford Management Contract } \\ \text { PNNL } & \text { Pacific Northwest National Laboratory } \\ \text { RL } & \text { U.S. Department of Energy, Richland Operations Office } \\ \text { RTP } & \text { readiness-to-proceed } \\ \text { SEMP } & \text { Systems Engineering Management Plan } \\ \text { SST } & \text { single-shell tank } \\ \text { TBR } & \text { Technical Basis Review } \\ \text { TBSD } & \text { Technical Baseline Summary Description } \\ \text { Tri-Party Agreement } & \text { Hanford Federal Facility Agreement and Consent Order } \\ \text { TRU } & \text { transuranic (waste) } \\ \text { TWRS } & \text { Tank Waste Remediation System } \\ \text { WBS } & \text { work breakdown structure }\end{array}$


This page intentionally left blank. 


\section{TANK WASTE REMEDIATION SYSTEM RETRIEVAL AND DISPOSAL MISSION READINESS-TO-PROCEED MEMORANDUM}

\subsection{INTRODUCTION}

The principal objective of the TWRS Project is to reduce the risk to the public and the environment that results from the approximately 54 million gallons of mixed and high-level waste (HLW) stored in 177 underground storage tanks at the Hanford Site.

On October 1, 1996, the U.S. Department of Energy (DOE), Richland Operations Office (RL) selected a Management and Integration (M\&I) Contractor for cleanup of the DOE's former nuclear production facilities. This contract award was predicated upon the PHMC team bringing technical and systems engineering skills to develop a technically Integrated Baseline for the Hanford Site and specifically the Tank Waste Remediation System (TWRS) Project. This need was fundamental to RL's strategy to solicit a tank waste treatment capability from private industry now known as "TWRS privatization," and contracts were placed with two private company teams in September 1996. Treatment of the tank wastes was divided into two phases: Phase 1, a demonstration phase; and Phase 2, a full-scale production phase. Phase 1 facilities are scheduled for operation from 2002 through 2005, with options to run through 2011, and will process up to 13 percent of the total Hanford Site tank waste. Both private contractors are participating in Phase 1 which is also divided into two parts; Phase 1A, preliminary technical phase; and Phase 1B, construction and demonstrated operation.

RL requested the PHMC team to develop the Technical Baseline documentation to establish readiness to support a tank waste retrieval and disposal program. RL is also conducting a review of DOE/EIS-0189, Tank Waste Remediation System, Hanford Site, Richland, Washington, Final Environmental Impact Statement (DOE and Ecology 1996), as committed in 62 FR 8693, "Record of Decision for the Tank Waste Remediation System, Hanford Site, Richland, WA." These separate actions, taken as a whole, will constitute the technical and financial basis for continuation of the program.

This memorandum addresses the following subject areas associated with PHMC team baseline planning and evaluation of readiness to proceed:

1.0 Introduction

2.0 PHMC team Workscope

3.0 Declaration of Readiness To Proceed

4.0 Readiness Evaluation Process

5.0 Summary of Retrieval and Disposal Mission Planning 


\subsection{MISSION SUMMARY}

The Hanford Site Integrated Technical Baseline establishes the top-level functional requirements that define the Hanford Site Cleanup Mission. This baseline allocates requirements to the TWRS Project, defines primary interfaces, and bounds the scope of the TWRS Project. The mission of the TWRS Project includes the retrieval, immobilization, storage and disposal of Hanford Site tank waste. Most of the waste is stored in 149 single-shell tanks (SSTs) and 28 double-shell tanks (DSTs). This highly hazardous and radioactive waste is the result of 50 years of plutonium production and processing. The tank waste poses substantial future potential risk to health and the environment. According to HNF-EP-0182-112, Waste Tank Summary Report for Month Ending July 31, 1997, sixty-seven of the 149 SSTs have leaked waste to the soil beneath the tanks (Hanlon 1997). Recent reports indicate that some of the leakage has reached the groundwater below the site (Schein 1997). The older SSTs will continue to pose risk to the public, the environment, and site workers from potential leakage over both the near and long term. Before significant progress can be achieved in reducing this risk, tank space must be made available in the DST system. An additional problem is that a byproduct of radioactive waste decay and chemical decomposition is the generation of flammable gases. These gases co-exist in tank headspaces and within the wastes and could lead to a significant hazards, if ignited. This risk will continue until the waste is removed and treated. Implementation of Phase 1 will pave the way for TWRS Project completion by: (1) immobilizing up to 13 percent of the tank waste, (2) retrieving waste from the most flammable gas waste tanks and, (3) making DST space available for SST retrieval.

DOE completed an EIS in 1996 (DOE and Ecology 1996) which examined a range of alternatives. The preferred alternative, phased retrieval, processing and immobilization, was compared with other alternatives. The results of the comparison indicated that billions of dollars would be required to retrieve and process the waste, or rebuild compliant storage tanks to safely store and manage the waste for the foreseeable future, or treat and immobilize the waste in place. The DOE decided to move forward with a compliant phased retrieve, process, and immobilize approach, rather than construct replacement storage tanks, or pursue in-situ treatment and disposal of the waste. The DOE plan uses an initial phase to demonstrate low activity and HLW separation and immobilization, to process up to 13 percent of the tank waste, followed by a larger scale production phase to complete the mission. This decision appears to be endorsed by the Washington State Department of Ecology (Ecology), U.S. Environmental Protection Agency (EPA), Hanford Advisory Board, Defense Nuclear Facilities Safety Board, the Indian Nations, and other vital stakeholders.

\subsection{EVALUATION OBJECTIVE}

On August 8, 1997, DOE issued letter 97-WDD-129, Contract Number DE-ACO6-96RL13200, Tank Waste Remediation System (TWRS) Privatization - Hanford Contractors Readiness-to-Proceed (Taylor 1997), requesting a formal evaluation of the PHMC team's readiness to proceed (RTP) with the Phase 1 mission. DOE also requested that an RTP Plan be prepared and that a memorandum addressing readiness be submitted by January 12, 1998. On October 31, 1997, the M\&I Contractor submitted HNF-SP-1241, Readiness-To- 
Proceed Plan for M\&I Contractor Workscope in Support of TWRS Phase $1 B$ Privatization (Wojtasek 1997). This memorandum, and the balance of the RTP evidence package, document the results of the work addressed in Wojtasek (1997) and fulfill DOE's request for an RTP memorandum.

The RTP evaluation objective includes demonstrating that the PHMC team can meet requirements to support the private contractors by providing the infrastructure, providing the waste feed for immobilization, and by receiving and managing the products and byproducts from the waste processing facilities. The RTP evaluation objective also includes demonstrating the following:

- The mission is clearly defined and requirements are understood

- An Integrated Baseline through 2011 is in place

- Risks and mitigating actions and assumptions and validation plans have been identified

- A management plan is in place and resource requirements have been identified.

\subsection{PHMC TEAM WORKSCOPE}

DOE has placed contracts (DE-AC06-96RL13308, British Nuclear Fuels Laboratory Privatization Contract [RL 1996a]; DE-AC06-96RL13309, Lockheed Martin Advanced Environmental Systems Privatization Contract [RL 1996b]) with two private contractors to plan facilities to immobilize tank waste as Phase 1 of the TWRS project. Contracting for privately owned and operated waste immobilization facilities is referred to as the TWRS Project "privatization initiative." Major programmatic milestones are summarized in Table 1. These milestones are based on the Hanford Federal Facility Agreement and Consent Order (Tri-Party Agreement) (Ecology et al. 1996) amendments (negotiated by RL, Ecology, and the EPA) and incorporate the phased privatization approach. Supporting DOE's waste immobilization activities and the remainder of the TWRS Project is key to the success of the PHMC team. Fluor Daniel Hanford, Inc. (FDH), the Hanford Site M\&I Contractor, and LMHC, the TWRS Project contractor, supported by the PHMC team, is responsible for the following workscope for Phase 1 of DOE's "privatization initiative:"

\section{Deliver waste feed to private contractors}

Retrieve waste from DSTs, (to make space available for SST retrieval and to retrieve waste from the most flammable gas waste tanks), complete necessary waste conditioning 
Table 1. Major Tank Waste Remediation System Milestones.

\begin{tabular}{|l|l|}
\hline \multicolumn{1}{|c|}{ Milestone } & \multicolumn{1}{c|}{ Date } \\
\hline Initiate LAW Immobilization (Phase 1) & June 2002 \\
\hline Initiate HLW Immobilization (Phase 1) (M-51-03) & December 2009 \\
\hline Complete SST Waste Retrieval (M-45-05) & September 2018 \\
\hline Complete LAW Immobilization (M-60-00) & December 2024 \\
\hline Complete Closure of SSTs (M-45-00) & September 2024 \\
\hline Complete HLW Immobilization (M-51-00) & December 2028 \\
\hline
\end{tabular}

HLW $=$ high-level waste.

LAW $=$ low-activity waste

SST $=$ single-shell tank.

and deliver low-activity waste (LAW) and HLW to the private contractors' staging tanks within specification to support immobilization operations

Provide necessary infrastructure

Provide utilities and selected site services to support the private contractor facilities.

Store and dispose of products and byproducts from the private contractors

Provide interim storage of immobilized HLW products, provide for disposal of immobilized LAW products, and provide for treatment, storage, or disposal of specified byproducts and secondary wastes received from the private contractors.

\subsection{DECLARATION OF READINESS TO PROCEED}

After evaluating the TWRS Project baseline, management systems, existing and planned hardware relative to the mission requirements, and target funding, the M\&I Contractor declares Readiness to Proceed with support to the TWRS Project Phase 1 Mission. This constitutes the PHMC team certification as requested in the August 8,1997 guidance letter issued by DOE (Taylor 1997).

The TWRS Project contractor will safely prepare and deliver the specified waste feed to the private contractors to allow tank waste processing to begin by June 2002. The TWRS Project Contractor's portion of the Phase 1 Mission is largely an extension of current operations of the TWRS Project. A critical path schedule has been established, and the required systems, staff, 
and documentation are either in place or plans have been developed to ensure they exist when needed. Existing plans confirm that the TWRS Project contractor will be able to sustain feed delivery, infrastructure support, and receipt and eventual disposal of immobilized and other waste products for the duration of Phase 1 (i.e., through FY 2011) consistent with specifications (including maximum order quantities of waste) in the existing DOE contracts with the private contractors. The Hanford Site M\&I Contractor confirmed that support and services (e.g., secondary waste treatment) needed for the TWRS Retrieval and Disposal Mission, that will be provided by members of the PHMC team outside the TWRS Project, is planned consistent with the scope, schedule, and cost in the TWRS Project baseline, and that clear lines of communication and interface controls exist.

Budget and resource requirements, including staffing, have been estimated for Phase 1 of the TWRS Retrieval and Disposal Mission. A financial analysis and financial risk assessment determined that, with added risk mitigation activities, there is a high degree of confidence that the work required between now and 2011 can be carried out for a cost that is within 10 percent of target funding levels. Any reductions in schedule float in response to budget issues will, however, impact the critical path schedule.

A number of planning assumptions were required to construct HNF-1946, Tank Waste Remediation System Retrieval and Disposal Mission Initial Updated Baseline Summary (Swita et al. 1998). These assumptions were largely derived from DOE guidance and DOE contracts (RL 1996a, 1996b) with the private contractors. These assumptions are consistent with existing policy and practices and do not require administrative or legislative changes for mission execution.

Overall risk associated with the TWRS Retrieval and Disposal Mission scope is manageable. Risks associated with technical, environmental, safety, health, cost, schedule, and management aspects of the updated baseline were evaluated at the working level of the work breakdown structure (WBS) and rolled up to the major mission element level. Cross-cutting risks and technical risks of a programmatic nature were also considered. As evidence of a robust risk management approach, mitigation measures were incorporated into the updated baseline to provide an acceptable probability of achieving technical, schedule, and cost expectations. The technical risks are relatively low because many of the required systems and operations already exist or are not technically complex. No new technology is needed to complete Phase 1 of the TWRS Retrieval and Disposal Mission. Schedules include float but will require close attention. DOE should be cognizant of the TWRS Project Contractor's planning assumptions. DOE should manage changes in contract specifications, policies, and procedures to avoid changes that would result in significant cost and schedule impacts or create technical challenges that may not be manageable within bounds of the M\&I Contractor Phase 1 work.

Management, management systems, and safety systems exist to support the TWRS Retrieval and Disposal Mission. Plans for upgrading and improving existing systems are in place and will result in increased efficiency, which is accounted for in the updated baseline cost estimate. The M\&I Contractor and the TWRS Project Contractor have demonstrated the ability to manage large, complex projects and have brought their corporate expertise to bear on this 
mission. The M\&I contract is definatized and provides the vehicle to clearly communicate and control the scope.

An analysis of the programmatic, management, and technical activities necessary to declare readiness to proceed with Phase 1 indicates that the systems, personnel, and hardware will be on line and ready to support initiation of waste immobilization beginning June 2002 . A systematic evaluation of the M\&I Contractor's ability to support the private contractors performing waste processing concluded that the systems, infrastructure, operations, and resources required to support the mission are known. Since October 1996, actions have been taken by DOE and the M\&I Contractor Team to establish a robust system engineering approach as part of the TWRS Project culture. System engineering principles, including the development and use of detailed logic diagrams, were used to develop the Tank Waste Remediation System Retrieval and Disposal Mission Initial Updated Baseline Summary (Swita et al. 1998). Completing the development and documentation of the remaining components of the Technical Baseline, per the updated TWRS Retrieval and Disposal Mission Schedule, will provide the TWRS Project Contractor with a sound technical foundation for operations.

\subsection{READINESS EVALUATION PROCESS}

The declaration of readiness provided in Section 3.0 is a direct result of the readiness evaluation process described in this section. Requirements, guidance, and criteria; management plans and program baseline; and analysis processes and products are addressed.

\subsection{REQUIREMENTS, GUIDANCE, AND CRITERIA}

On August 8, 1997, DOE issued formal RTP evaluation guidance to the M\&I Contractor (Taylor 1997). In addition, DOE Orders 430.1, Life Cycle Asset Management, and 425.1, Startup and Restart of Nuclear Facilities, and the associated Good Practice Guide, GPG-FM-02, Critical Decision Criteria, were adopted as primary guidance for planning. Taylor (1997) provides overall guidance associated with the RTP evaluation and the mission of Phase 1 . The DOE Order 430.1 and GPG-FM-002 address the preconceptual through turnover phases of a project life cycle. The DOE Order 425.1 and the associated 20 minimum core requirements for startup and restart address the operations and maintenance phase of a project life cycle.

The PHMC RTP team analyzed the primary sources identified above and other appropriate sources (e.g., Integrated Site Technical Baseline, Phase 1A contracts with the private contractors and existing TWRS project plans, requirements, and guidance documents) and established RTP program elements (Figure 1). Requirements and guidance statements were then 
Figure 1. Identification of Criteria and Deliverables.

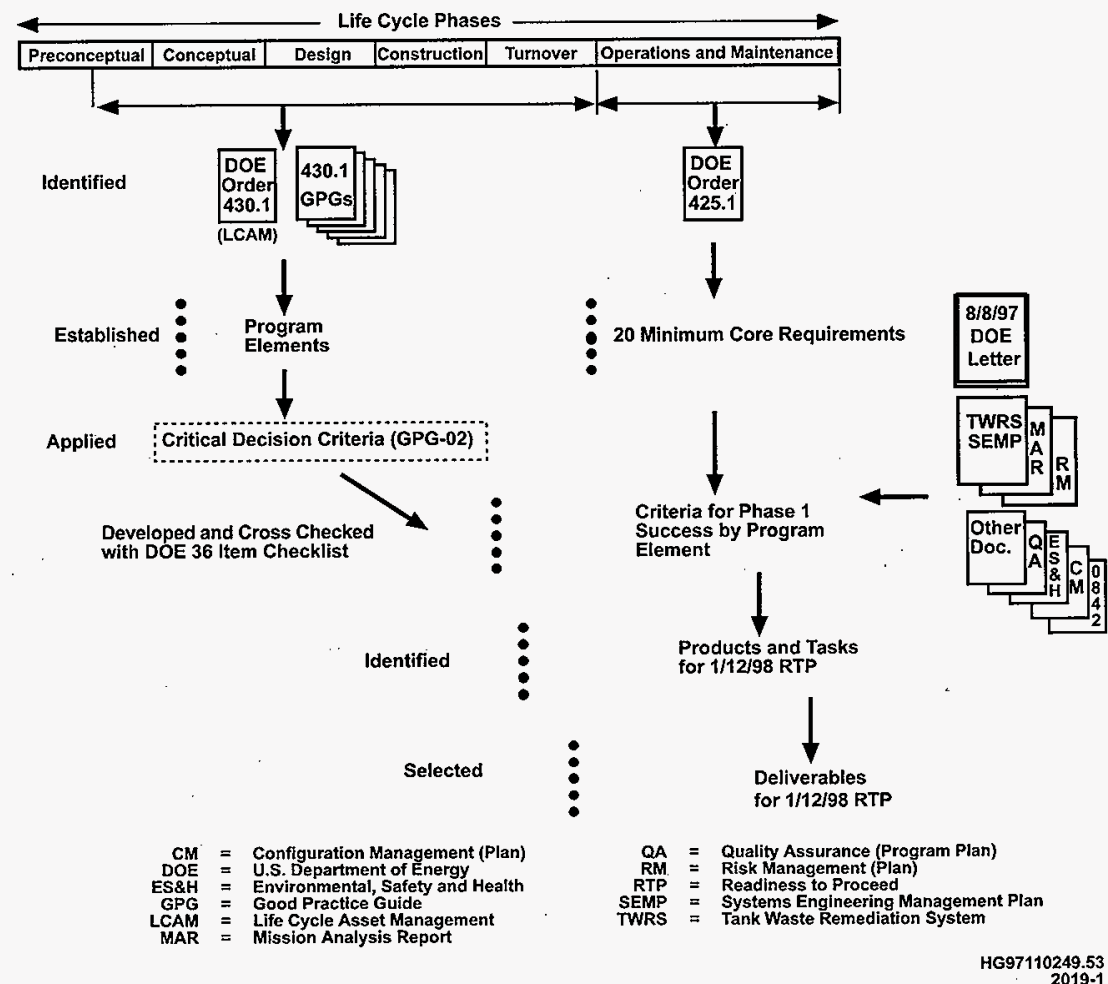

identified for each program element. The RTP criteria were then developed for each program element, considering the identified requirements and guidance statements and the appropriate level of readiness commensurate with the life cycle of the mission. The criteria were cross checked for completeness against the 36-item checklist in Appendix B of Taylor (1997). The RTP technical products were then identified and the developed criteria were used to establish specific tasks associated with each product. Key products were then selected as January 1998 deliverables, and an RTP document hierarchy (Figure 2) was developed. Because guidance and 
Figure 2. Readiness to Proceed Document Hierarchy.

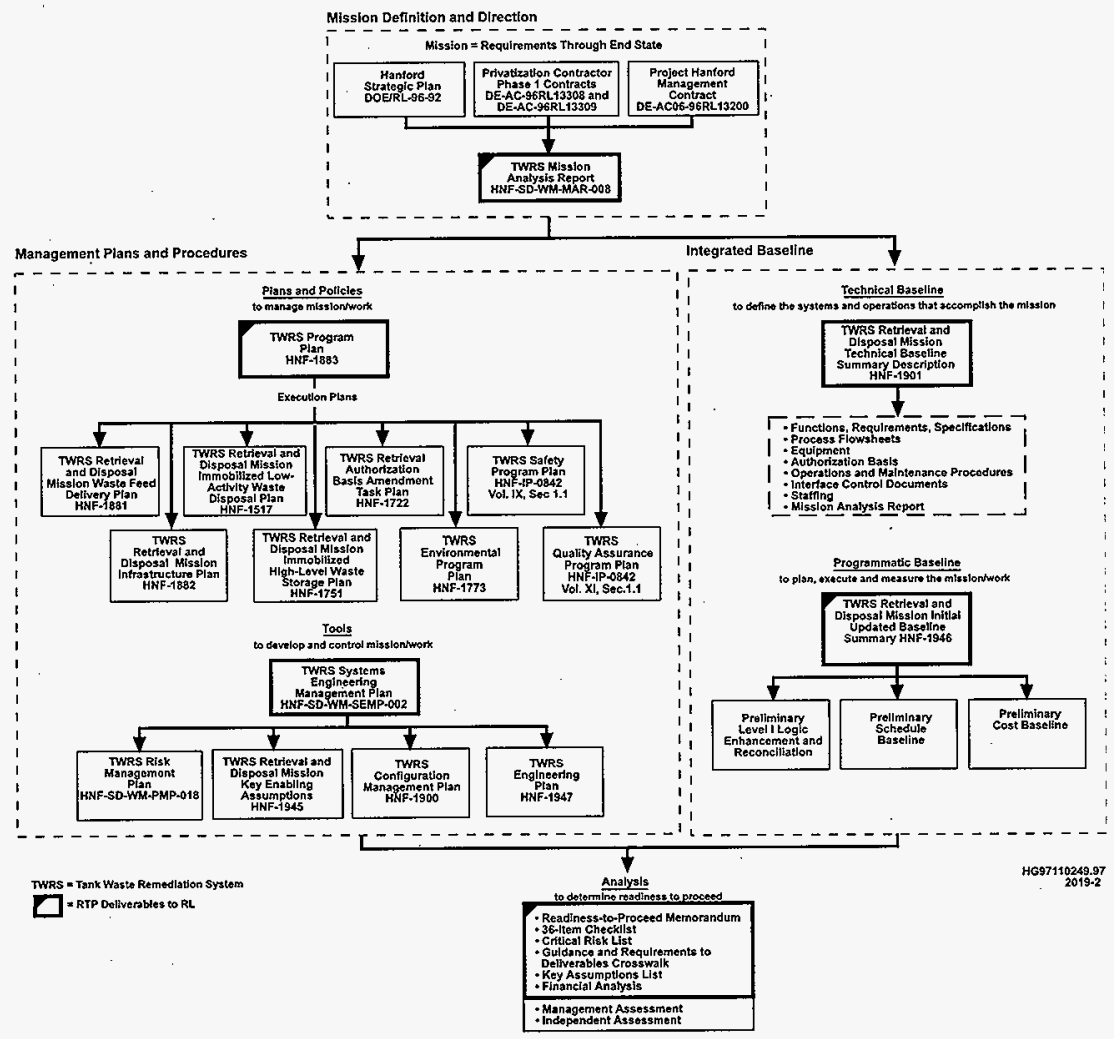

requirements are quite extensive, and because a comprehensive set of mission documentation has been developed, a crosswalk (HNF-2020, Tank Waste Remediation System Retrieval and Disposal Mission Readiness-to-Proceed Guidance and Requirements to Deliverables Crosswalk [Hall 1998]) was constructed to link each guidance or requirement item to one or more mission documents (Section 4.3.1). 
The RTP document hierarchy identifies the technical products and RTP deliverables that comprise the RTP evidence package, and the relationship between technical products. The RTP document hierarchy represents the four basic elements of the RTP evidence package: Mission Definition and Direction; Management Plans and Procedures, Integrated Baseline; and Analysis.

\subsection{MANAGEMENT PLANS AND PROGRAM BASELINE}

The management plans and program baseline section addresses the processes and products associated with the mission definition and direction, management plans and procedures, and Integrated Baseline elements of the RTP evidence package.

\subsubsection{Mission Definition and Direction}

Between October 1996 and September 1997, both DOE and the PHMC team worked aggressively to refine the TWRS Retrieval and Disposal Mission and develop a technically Integrated Baseline. During this period the workscope was decomposed into a master WBS that recognizes the integrated nature of the workscope planning. In addition, tank upgrades and transfer pipeline improvements necessary to meet the batch feed rates prescribed for the private contractors were determined. These efforts represent significant improvements in TWRS Project and Hanford Site mission definition, direction, and Technical Baseline planning.

As part of the RTP effort, the PHMC team evaluated and updated HNF-SD-WM-MAR-008, Tank Waste Remediation System Mission Analysis Report (TWRS MAR) (Acree 1998). The TWRS MAR is the RTP deliverable that represents the mission definition and direction element of the evidence package. The TWRS MAR explains the mission, identifies requirements, and describes the steps necessary to achieve the desired end state. The MAR has been reviewed against DOE/RL 96-92, Hanford Strategic Plan (RL 1996c); current private contractor Phase 1A contracts; and DE-AC06-96RL13200, Project Hanford Management Contract (PHMC) (RL 1996d), to assure consistency and integration. Facility specifications identified as necessary to support Phase 1 in the MAR have been planned and scheduled in Swita et al. (1998). Certain lower-level technical decisions associated with these specifications will be made during the development of these specifications according to the schedule included in the updated baseline. The HNF-1945, Tank Waste Remediation System Retrieval and Disposal Mission Key Enabling Assumptions (Baldwin et al. 1998), identifies key assumptions used to develop the updated baseline. The TWRS Retrieval and Disposal Mission is clearly defined as a result of the mission analysis activities conducted by DOE and the PHMC team over the last 15 months.

\subsubsection{Management Plans and Procedures}

The PHMC team recognizes the importance of solid planning, policy, and execution documentation to the conduct and control of the work. As part of the RTP evaluation process, 
existing TWRS Project documentation was assessed and, where necessary, improved. RTP Team members drew upon the resources within their organizations, as well as external expertise, as needed. Senior management and senior external consultants played an active role in the production of the documents to assure that approved documentation represented an integrated, comprehensive roadmap for TWRS Retrieval and Disposal Mission success.

The HNF-1883, Tank Waste Remediation System Program Plan (Freeman 1998), is the RTP deliverable that represents the management plans and procedures element of the evidence package. Freeman (1998) is consistent with the TWRS MAR (Acree 1998) and describes the overall management approach and organizational roles and responsibilities, and addresses performance measures for the TWRS Project. As indicated in Figure 2, a number of lower-tier program documents also were established to enhance management of the mission and the work. Lower-tier documents include program plans directed at specific elements of the mission workscope: HNF-1722, Tank Waste Remediation System Retrieval and Disposal Mission Authorization Basis Amendment Task Plan (Goetz et al. 1998); HNF-IP-0842, TWRS Administration, Volume IX, "Safety," Section 1.1, "TWRS Safety Program Plan" (LMHC 1998); HNF-1773, Tank Waste Remediation System Environmental Program Plan (Borneman 1998); and HNF-IP-0842, Volume XI, "Quality Assurance," Section 1.1, "TWRS Quality Assurance Program Plan" (LMHC 1998). These plans describe the ongoing implementation of the TWRS Project safety management system to the worker safety level and the environmental and quality assurance approach and requirements for mission success.

The Tank Waste Remediation System Systems Engineering Management Plan (SEMP), HNF-SD-WM-SEMP-002 (Peck 1998), provides the guidance for developing the Technical Baseline needed to develop, deploy, and operate systems to satisfy mission needs. The TWRS SEMP describes the process by which requirements allocated to TWRS Project by the Hanford Site Integrated Baseline are captured and allocated to elements of the TWRS Project Integrated Baseline in a systematic manner. The TWRS SEMP also describes the process by which the technical requirements baseline will continue to evolve from the mission level to specific requirements for individual construction projects. Lower-tier documents associated with development and control of the mission and work include HNF-SD-WM-PMP-018, Tank Waste Remediation System Risk Management Plan (Zimmerman 1998a); TWRS Retrieval and Disposal Mission Enabling Assumptions (Baldwin et al. 1998); HNF-1900, Tank Waste Remediation System Configuration Management Plan (Vann et al. 1998); and HNF-1947, Tank Waste Remediation System Engineering Plan (Rifaey 1998).

The RTP evaluation process has demonstrated that necessary management plans have been developed and approved by the PHMC team to support a positive declaration of RTP with Phase 1. The TWRS Retrieval and Disposal Mission management approach and management tools have been defined, and risks, mitigation actions, assumptions, and assumption validation actions have been identified. 


\subsubsection{Integrated Baseline}

An important element of the RTP process was the evaluation and enhancement of the Integrated Baseline (Figure 3). An activity-by-activity critical path decomposition (i.e., detailed activity identification) was necessary to conduct a mission financial analysis and risk assessment.

Figure 3. Integrated Baseline Development.

Hanford Site

Technical Baseline

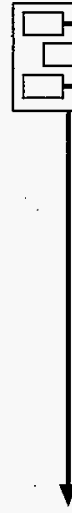

Activity-By-Activity

Critical Path

Decomposition

TWRS Level 0

Logic

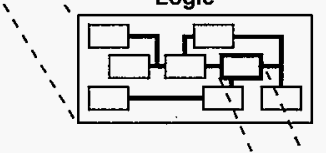

TWRS Level 1 Logic

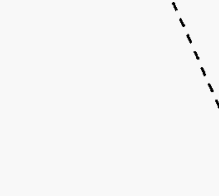

11<smiles>C1CCCCC1</smiles>

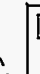

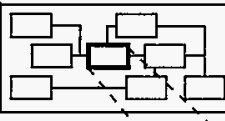

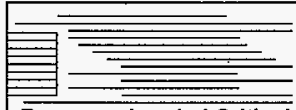

Resource Loaded Critical Path Schedule

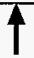

Planning Detail

- Logic

- Scope Definition

- Interfaces

- Assumptions

- Risks

- Activity Duration

- Activity Resource Requirements
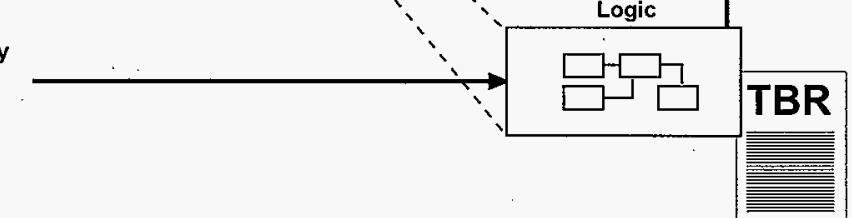

TBR = Technical Basis Review

TWRS = Tank Waste Remediation System 
The M\&I Contractor established an integrated RTP Team to complete this effort. The RTP Team started with the mission logic for the Hanford Site and the TWRS Project developed in FY 1997. The mission logic is a key element of the TWRS Project Systems Engineering Program. A robust systems engineering program is a fundamental requirement of the mission. Ongoing communication with the Defense Nuclear Facilities Safety Board (letter to Federico F. Peña, Secretary, U.S. Department of Energy [Conway 1997]) and Ecology (letter to J. D. Wagoner, Manager, U.S. Department of Energy, Richland Operations Office [Wilson 1997]) confirms the importance of the mission logic.

The Level 1 mission logic identifies the individual activities that comprise Phase 1. Approximately one third of the activities can be used as a basis for defining the overall technical workscope required for mission success. These activities were used as the starting point for logic, interface, scope, assumption, risk, schedule, and resource requirement evaluations. Program element subteams representing the functional areas evaluated existing planning, established more detailed logic and enhanced scope definition, interface data, assumptions, risk data, activity durations, and resource requirement data for each activity. Program execution plans were developed for each functional area. Activity planning evaluation and enhancement included staff training. The data generated during this process was used to establish a formal data package (i.e., a Technical Basis Review (TBR) package) for each of these activities. TBR packages were then reviewed by the entire RTP Team, revised as appropriate, approved by team members and placed under configuration control. The planning detail captured in the TBR packages was used to produce an enhanced resource-loaded critical path schedule and to conduct a financial analysis and risk assessment. Enhanced planning detail and estimates of resource requirements will significantly increase the likelihood of preventing schedule and cost issues on projects.

Risk management is an integral part of the overall TWRS Project work planning process. Risks are derived from and linked to the TWRS mission analysis, program logics, and critical path assessment. Detailed risk and enabling assumption data generated during the baseline evaluation and enhancement process was used to enhance program level risk and enabling assumption documentation.

The Integrated Baseline element of the evidence package includes the Technical Baseline and the Programmatic Baseline. The RTP product that represents the Technical Baseline is HNF-1901, Tank Waste Remediation System Retrieval and Disposal Mission Technical Baseline Summary Description (TBSD) (Treat et al. 1998). The Technical Baseline addresses functions, requirements, specifications, process flowsheets, equipment, Authorization Basis, operations and maintenance procedures, interface control documents (ICDs), staffing, and mission analysis.

The RTP deliverable that represents the programmatic element of the Integrated Baseline is the Tank Waste Remediation System Retrieval and Disposal Mission Initial Updated Baseline Summary (Swita et al. 1998). The updated baseline includes a product oriented, resource loaded critical path schedule through 2011 based on the technical and administrative activities identified on the Level 1 Logic. The schedule documents logic ties, interfaces, performing organizations and project areas, critical path, and resource requirements based on detailed cost estimates with 
documented basis of estimate information included in the TBR packages. The updated baseline provides vertical integration among the schedule details, the Project Master Baseline Schedule, and the Site Master Baseline Schedule and represents the plan to execute and measure the mission and the work. The updated baseline represents documented planning to achieve TWRS Project waste transfer startup to support initiation of waste immobilization beginning June 2002 and maintain safe, reliable operations through 2011 as specified. The TBSD Treat et al. (1998) and Swita et al. (1998) provide evidence of an Integrated Baseline (scope, schedule and resource requirements) through 2011.

\subsection{ANALYSIS PROCESSES AND PRODUCTS}

The PHMC team completed a formal evaluation of readiness to proceed with the TWRS Retrieval and Disposal Mission. Commitments from all levels of management resulted in a thorough evaluation process, focused not only on responding to customer requirements and guidance, but also to a detailed analysis of mission status and the prerequisites to mission success. A multilevel evaluation approach, including a structured independent appraisal, was used. A requirements and guidance assessment, mission analysis, critical path analysis, and financial analysis provided the information necessary for a management assessment of technical and Programmatic Baseline status and risks. The PHMC team effort resulted in an RTP evaluation and evidence package that fully responds to the August 8,1997 DOE guidance letter (Taylor 1997). The RTP memorandum, the statused 36 Item Checklist (from Taylor [1997]), a List of Critical Risks, a Guidance and Requirements to Deliverables Crosswalk, a List of Key Assumptions, and a Financial Analysis Report are the RTP deliverables associated with the analysis element of the evidence package.

\subsubsection{Guidance and Requirements to Deliverables Crosswalk}

During the early stages of the RTP effort, the need for a systematic method of crosschecking requirements and guidance to mission documentation was identified. Because guidance and requirements are quite extensive and because a comprehensive set of mission documentation has been developed, a crosswalk was constructed to link each guidance or requirement item to one or more mission documents. Senior management used the crosswalk during the management assessment of readiness to assure that each guidance or requirement item had been appropriately addressed. The crosswalk (Hall 1998) is part of the RTP deliverable package. A Guidance and Requirements to Deliverables Crosswalk specific to the RTP memorandum is provided in Appendix B. Appendix $\mathrm{C}$ specifically addresses the 10 monthly review areas from paragraph 4.2.4 of the August 8, $1997 \mathrm{DOE}$ Guidance Letter (Taylor 1997).

\subsubsection{Statused 36 Item Checklist}

The 36 item checklist for M\&I Contractor readiness to proceed was provided to the M\&I Contractor for evaluation of readiness with the August 8,1997 guidance letter from DOE 
(Taylor 1997). The checklist provides current RTP status and is included as Appendix A of the PHMC team RTP memorandum.

\subsubsection{Structured Independent Appraisal}

In addition to a comprehensive senior management assessment, the PHMC team evaluation of RTP included a structured and independent appraisal of the PHMC team's RTP with the TWRS Retrieval and Disposal Mission. The appraisal was conducted by an independent review team and used a structured process that included the preparation of criteria and a review approach for each RTP product reviewed. The process included review of RTP products, interviews with RTP Team members, the preparation of review forms that documented observations and/or recommendations, and the preparation of an independent review team final report.

Members of the review team were selected for their particular expertise in operations and maintenance; environmental, safety, and quality assurance; technical baseline; business management; and stakeholder involvement. Voting members of the review team were qualified to American National Standards Institute/American Nuclear Society requirements ANSI/ANS-3.1-1993, Selection, Qualification, and Training of Personnel for Nuclear Power Facilities, Sections 4.7.1 and 4.7.2 for independent reviews. A list of team members and a discussion of the review criteria and approach are included in HNF-2018, Tank Waste Remediation System Retrieval and Disposal Mission Readiness-to-Proceed Internal Independent Assessment (Schaus 1997). The report includes a list of observations and recommendations and identifies the disposition of each observation and recommendation. Since the independent review concluded several weeks before submittal of the RTP evidence package to DOE, many of the review team's recommendations have been incorporated. The report indicates that the PHMC team demonstrated a clear and complete understanding of the workscope required. The report further indicates that if planned activities are adequately funded and carried out, and the issues identified by the review team are addressed, "there is reasonable assurance that the M\&I Contractor will be able to deliver waste to the private contractor for the duration of Phase 1B" (Schaus 1997).

\subsubsection{Financial Analysis}

The purpose of the financial analysis element of the RTP evaluation was to provide a cost and schedule risk analysis of Swita et al. (1998). The analysis addressed the executability of the updated baseline, proper funding levels for scheduled activities, and recommends a path forward for risk mitigation. Key to the financial analysis is the fact that each scheduled TWRS Retrieval and Disposal Mission activities' enabling assumptions, risk issues, risk mitigation actions, and estimating assumptions/exclusions/risks were documented in the updated baseline Technical Basis Review and cost estimating input sheets. 
A detailed analysis of the overall costs to prepare for and perform the Phase $1 \mathrm{~B}$ portion of the TWRS Retrieval and Disposal Mission was completed. The analysis process and results are discussed in detail in HNF-2017, Tank Waste Remediation System Retrieval and Disposal Mission Phase I Financial Analysis (Wells 1998), which is part of the RTP deliverable package. The analysis concluded that the scope of work documented in Swita et al. (1998) can be completed per the schedule included therein. In general, TWRS Project cost requirements for the period FY 1998 through FY 2011 are $\$ 5.4$ billion or within 10 percent ( $\$ 458$ million) of the current target baseline. The Phase 1B Retrieval and Disposal Mission portion of the $\$ 5.4$ billion is $\$ 2.4$ billion. An analysis of risks indicates an execution probability of $80 \%$ at this value. The $\$ 458$ million above the current target baseline is related to added scope and risk mitigation activities that increase the execution probability from $50 \%$ to $80 \%$. Some near term noncritical path adjustments ( $\$ 5$ million) are required in FY 1998. Ten million dollars of additional funds in FY 1999 are required to ensure critical path activities are fully funded.

\subsubsection{Key Assumptions and Critical Risks}

A list of key assumptions (Baldwin 1998) and Tank Waste Remediation System Retrieval and Disposal Mission Critical Risk List (Zimmerman 1998b) have been developed as part of the RTP evidence package. Identification of enabling assumptions (and the associated planned resolution actions) and identification of technical and programmatic risks (and the associated planned mitigation actions) were critical elements of the analysis portion of the RTP effort. Assumptions and risks that were analyzed using the information compiled during the Integrated Baseline development process are discussed in more detail in Section 5.5. Lists of key assumptions and critical risks are included in the RTP deliverable package.

\subsection{SUMMARY OF RETRIEVAL AND DISPOSAL MISSION PLANNING}

The TWRS Contractor developed plans that satisfy the requirements for supporting the DOE's private contractors during Phase 1 of the TWRS Retrieval and Disposal Mission. The plans address technical and management aspects of the mission and control important interfaces and interactions and were an important basis for the declaration of readiness provided in Section 3.0. The sections describe the following:

- Background and evolution of the TWRS Retrieval and Disposal Mission

- Baseline development

- Technical plans

- Management approach

- The most significant risks and assumptions underlying the baseline with recommendations for reducing cost and risk for the Phase 1 enterprise. 


\subsection{BACKGROUND AND EVOLUTION OF THE TWRS RETRIEVAL AND DISPOSAL MISSION}

The Hanford Site was established in 1943 as part of the Manhattan Project. The Site's mission was to produce plutonium for nuclear weapons. Over the years, nine reactors and two large areas containing several nuclear chemical processing complexes were operated. The chemical processing operations produced large quantities of highly radioactive wastes. Today, approximately 54 million gallons of high-level radioactive waste are stored in 177 underground tanks.

In the early 1980 s, Congress requested the DOE to prepare plans for the disposal of the HLW that had accumulated from the DOE's nuclear activities. In 1983, the DOE issued the Defense Waste Management Plan. The proposed strategy was that waste would be retrieved from storage tanks and treated to make it suitable for disposal. Because facilities costing billions of dollars would be needed, and because facilities like these had not been built before, a sequential approach was selected. Facilities to treat the waste at the DOE's Savannah River Site in South Carolina would be constructed first. After processing was successfully demonstrated, facilities would be built at the Hanford Site, followed by facilities at the DOE's Idaho site. Facilities began operating at the Savannah River Site in 1996; therefore, proceeding with facilities at the Hanford Site is the next step in this planned progression.

In 1987, the Hanford Defense Waste EIS was issued which laid out a strategy for addressing the tank waste at the Hanford Site. Waste from DSTs would be retrieved. The highly radioactive fraction would be immobilized in glass (vitrified), and the low-activity fraction would be solidified in cement (grout) for disposal on the Hanford Site. This strategy was the basis for the Tri-Party Agreement negotiated by the DOE, the Washington State Department of Ecology, and the Environmental Protection Agency in 1989 (Ecology et al.).

In early 1990 , issues regarding the waste in the tanks were identified that appeared to pose unacceptable risks for continued storage without corrective actions. Technical and financial resources were directed at these issues. DOE reconsidered requirements of the Resource Conservation Recovery Act of 1976 and the Nuclear Waste Policy Act of 1982 and decided to include retrieval and treatment of the SST waste in the planning for the waste disposal program. The four-fold increase in the waste volume to be treated resulting from retrieval of SSTs, along with concerns about using an old facility (B plant) for waste pretreatment and concerns about using the proposed grout waste form for LAW disposal, caused a reevaluation of the strategy.

In December 1991, the Secretary of Energy directed that the TWRS Project be established to plan and implement the disposal of all tank waste at the Hanford Site. A system engineering approach was used to evaluate various alternatives. These studies were used to renegotiate the Tri-Party Agreement. A strategy was developed and negotiated and the revised Tri-Party Agreement was signed in January, 1994. The strategy envisioned :

- $\quad$ Retrieval of waste from both SSTs and DSTs 
- Separation of waste into high-activity and low-activity fractions

- Immobilization of the low-activity fraction in glass or other suitable form that would reduce volume and meet long-term disposal requirements

- Vitrification of the high-activity fraction for disposal in a national repository for HLW.

In 1994, national concern about balancing the Federal budget became a more significant issue. The DOE believed that a new approach was needed for funding and managing the construction and operation of the multi-billion dollar facilities needed for waste treatment and immobilization. After considering past experience and input from commercial industry, the DOE -decided on a "Privatization" approach to accomplish tank waste treatment at the Hanford Site.

As it is being used for TWRS, privatization is a fixed-unit price contracting method for providing waste treatment and immobilization services. The DOE will award competitively bid contracts under which the contractor will design, build, and operate waste immobilization facilities.

This project is divided into two phases primarily to reduce the risk of going directly to full-size facilities by successfully demonstrating the ability of all parties to support activities before making the large capital investments for full-scale facilities. The capacity of a facility to process all the waste in a reasonable time will be several times larger than anything built thus far, so a demonstration phase is appropriate. This strategy reduces the contractors' technical risks, and proves the ability to process waste containing Hanford Site materials.

\subsection{BASELINE DEVELOPMENT}

Between October 1996 and September 1997, DOE and the TWRS Contractor worked aggressively to refine the Retrieval and Disposal Mission, develop a technically Integrated Baseline to achieve the mission, and decompose the workscope into a Master WBS that recognizes the integrated workscope to achieve the mission. Baseline development focused on requirements to successfully startup and complete the Phase 1 mission (Figure 4). 
Figure 4. Top-Level Summary of Technical Basis for Operations.

CAA $=$ Clean Air Act

EIS = Environmental Impact Statement

ES\&H = Environmental, Safety and Health

$F \& R=$ Functions and Requirements

FDH = Fluor Daniel Hanford, Inc.

FONSI $=$ Finding of No Significant Impact

$H \& S=$ Health and Safety

ICD = Interface Control Documents

LMHC = Lockheed Martin Hanford Corporation

M\&I = Management and Integration

NEPA = National Environmental Policy Act of 1969

O\&M = Operations and Maintenance

ORR = Operational Readiness Review

PHMC = Project Hanford Management Contract

$Q A=$ Quality Assurance

$R A=$ Readiness Assessmen

ROD $=$ Record of Decision

SEMP $=$ Systems Engineering Management Plan

TWRS

Tank Waste Remediation System

Washington Administrative Code

1969

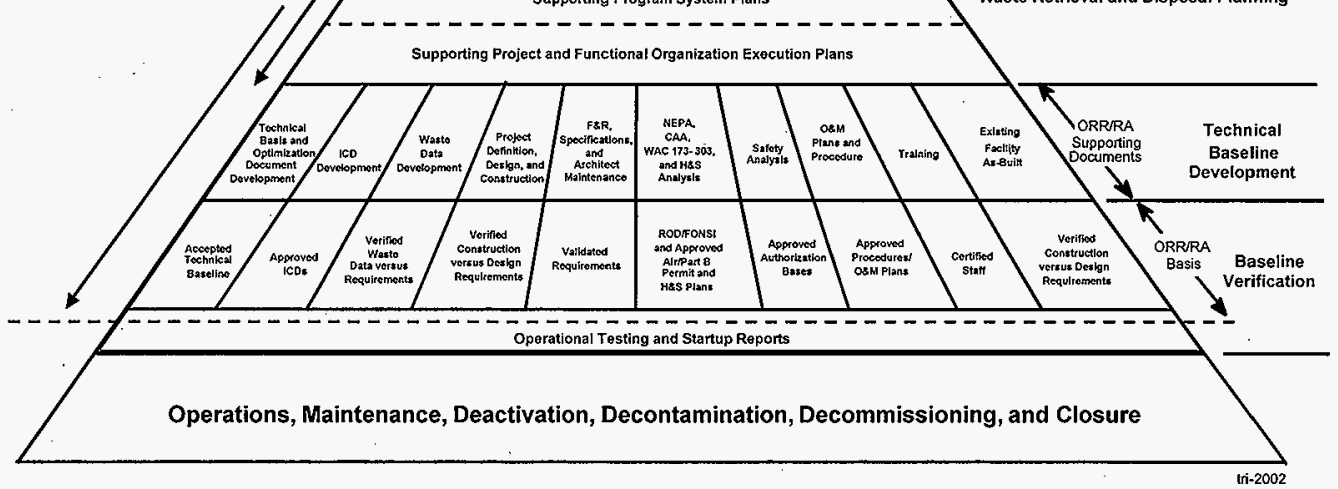

TWRS Waste Disposal Mission Definition 
The Technical Baseline is the science and engineering, equipment, facilities, materials, qualified staff, and enabling documentation need to startup and complete mission objectives. The Hanford Site Integrated Technical Baseline establishes the top-level functional requirements that define the Hanford Site Cleanup Mission. This baseline allocates requirements to the functions that make up the TWRS Project. Systems engineering methodology is applied to develop the detailed technical scope for the Phase 1 Retrieval and Disposal Mission (Acree 1998). The TBSD (Treat et al. 1998) identifies the documentation that represents the Technical Baseline and defines source information in each document.

Activity schedule logics were developed based on the mission-based planning assumptions and the components of the Technical Baseline including process requirements and information for existing or planned hardware and facilities. The logics (and backup material) describe the activities, their sequence, duration, and relationships. This information is used to develop a critical path schedule for the Retrieval and Disposal Mission. The Tank Waste Remediation System Retrieval and Disposal Mission Initial Updated Baseline Summary (Swita et al., 1998) is provided as part of the RTP evidence package. The Integrated Baseline is also described in Section 4.2.3.

\subsection{TECHNICAL PLANS}

\subsubsection{Planning Assumptions}

The Privatization Request for Proposal and DOE contracts with the two private contractors (RL 1996a; RL 1996b) define four waste feed envelopes (A, B, C, and D) to demonstrate the private contractor's processing capabilities (Table 2). Those contracts also provide specifications for schedules, processing rates, waste products and secondary wastes, and interfaces with the M\&I Contractor for the Hanford Site. These contract specifications in conjunction with planning guidance from DOE (see Section 4.1) were used by the TWRS Contractor to develop planning assumptions for the M\&I Contractor's responsibilities regarding this privatization strategy (Table 3 ). The planning assumptions enabled the TWRS Contractor to develop technical plans and schedules. These assumptions appear in the TWRS Retrieval and Disposal Mission Enabling Assumptions (Baldwin et al. 1998). The private contractors are assumed to process the maximum order quantity of waste during Phase 1 (Table 4).

The planning assumptions are consistent with the existing contracts and guidance and are conservative in terms of likely immobilization rates and immobilization process performance. The assumptions, however, may not be consistent with final DOE contracts with the private contractors because of changes in specifications or different strategies to meet the existing specifications. The TWRS Contractor has developed a simulation model that will allow DOE to rapidly determine the ability of the planned system to meet alternative specifications. This tool will support DOE's evaluations of the cost and schedule implications of alternative specifications during contract negotiations. 
Table 2. Waste Feed Envelopes Summary.

\begin{tabular}{|l|l|}
\hline Envelope & \multicolumn{1}{|c|}{ Description } \\
\hline $\mathrm{A}$ & $\begin{array}{l}\text { Waste that tests the production capacity and fission-product removal efficiency. } \\
\text { Produces a final product in which waste loading is limited by sodium. }\end{array}$ \\
\hline $\mathrm{B}$ & $\begin{array}{l}\text { Similar to } \mathrm{A}, \text { except that final product waste loading is limited by minor } \\
\text { component concentrations (Cl, } \mathrm{Cr}, \mathrm{F}, \mathrm{PO}_{4}, \text { or } \mathrm{SO}_{4} \text { ). These minor components may } \\
\text { stress the privatization contractor facilities' offgas system. }\end{array}$ \\
\hline $\mathrm{C}$ & $\begin{array}{l}\text { Contains organic complexants which keep }{ }^{90} \mathrm{Sr} \text { and TRU in solution. May require } \\
\text { organic destruction. }\end{array}$ \\
\hline $\mathrm{D}$ & $\begin{array}{l}\text { Contains insoluble solids classified as } \mathrm{HLW} \text { waste. The envelope approximates } \\
\text { solids content in three existing double-shell tanks: AZ-101, AZ-102, and AY-102 } \\
\text { (including C-106). }\end{array}$ \\
\hline
\end{tabular}

HLW $=$ high-level waste.

LAW $=$ low-activity waste.

$\mathrm{TRU}=$ transuranic.

Table 3. Major Requirements and Assumptions That Influence the Operating Scenario. (2 Sheets)

\begin{tabular}{|l|l|}
\hline \multicolumn{1}{|c|}{ Major requirement } & Area influenced \\
\hline Envelope definitions for LAW and HLW feed & LAW feed; HLW feed \\
\hline Order quantities for LAW and HLW feed & $\begin{array}{l}\text { LAW feed; HLW feed } \\
\text { IHLW interim storage } \\
\text { ILAW disposal }\end{array}$ \\
\hline Minimum batch sizes for LAW and HLW feed & LAW feed; HLW feed \\
\hline Minimum system capacity demonstration & $\begin{array}{l}\text { LAW feed; HLW feed } \\
\text { IHLW interim storage } \\
\text { ILAW disposal }\end{array}$ \\
\hline $\begin{array}{l}\text { Schedule for proof-of-concept (processing minimum order quantities) and extension } \\
\text { period (processing maximum order quantities) }\end{array}$ & $\begin{array}{l}\text { LAW feed; HLW feed } \\
\text { IHLW interim storage } \\
\text { ILAW disposal }\end{array}$ \\
\hline Minimum WOL in IHLW & IHLW interim storage \\
\hline Maximum ILAW package volume per unit of LAW feed delivered & ILAW disposal \\
\hline \multicolumn{1}{|c|}{ Major enabling assumption } & Area influenced \\
\hline $\begin{array}{l}\text { Two LAW facilities will be operated } \\
\text { One HLW facility will be operated }\end{array}$ & $\begin{array}{l}\text { LAW feed; HLW feed } \\
\text { IHLW interim storage } \\
\text { ILAW disposal }\end{array}$ \\
\hline
\end{tabular}


Table 3. Major Requirements and Assumptions That Influence the Operating Scenario. (2 Sheets)

\begin{tabular}{|l|l|}
\hline \multicolumn{1}{|c|}{ Major requirement } & \multicolumn{1}{|c|}{ Area influenced } \\
\hline Maximum order quantities will be processed & $\begin{array}{l}\text { LAW feed; HLW feed } \\
\text { IHLW interim storage } \\
\text { ILAW disposal }\end{array}$ \\
\hline $\begin{array}{l}\text { HLW processing rate of 0.164 MT NVOL/day (average over each individual feed } \\
\text { batch). }\end{array}$ & $\begin{array}{l}\text { HLW feed } \\
\text { IHLW interim storage }\end{array}$ \\
\hline $\begin{array}{l}\text { LAW processing rate of 2.0 MT Na/day/contractor (average over each individual feed } \\
\text { bath). }\end{array}$ & $\begin{array}{l}\text { LAW feed } \\
\text { ILAW disposal }\end{array}$ \\
\hline IHLW is delivered at the minimum allowable WOL. & IHLW interim storage \\
\hline $\begin{array}{l}\text { 59lCanisters (3.0 meters) allocated for IHLW storage including IHLW, dry cesium, } \\
\text { and non-routine HLW. }\end{array}$ & IHLW interim storage \\
\hline $\begin{array}{l}\text { The private contractors achieve the values of ILAW package volume per unit of LAW } \\
\text { feed delivered stated in Brown (1996). }\end{array}$ & ILAW disposal \\
\hline $\begin{array}{l}\text { LAW feed will be qualified (certified) in the source tank when necessary to support the } \\
\text { assumed processing rates. }\end{array}$ & LAW feed \\
\hline $\begin{array}{l}\text { The tank space projections in the Operational Waste Volume Projections (Strode and } \\
\text { Boyles } 1997) \text { remain valid. }\end{array}$ & LAW feed; HLW feed \\
\hline $\begin{array}{l}\text { The entire feed qualification process takes no longer than 85 days for LAW feed and 68 } \\
\text { days for HLW. }\end{array}$ & LAW feed; HLW feed \\
\hline $\begin{array}{l}\text { New ILAW disposal facilities can be authorized, designed, constructed, and ready to } \\
\text { operate in a 3.5-year period. }\end{array}$ & ILAW disposal \\
\hline
\end{tabular}

Brown, N. R., 1996, LLW Product Waste Loading Assumptions for the TWRS Process Flowsheet, (internal memorandum to R. M. Orme, April 23) U.S. Department of Energy, Richland, Washington.

Strode, J. N., and V. C. Boyles, 1997, Operational Waste Volume Projection, HNF-SD-WM-ER-029, Rev. 23, prepared by Lockheed Martin Hanford Corporation for Fluor Daniel Hanford, Inc., Richland, Washington.

HLW $=$ high-level waste.

IHLW $=$ immobilized high-level waste.

ILAW = immobilized low-activity waste.

MT $=$ metric ton.

NVOL $=$ nonvolatile oxides less sodium and silicon.

WOL $=$ waste oxide loading.

LAW $=$ low-activity waste.

Table 4. Comparison of Low-Activity Waste and High-Level Waste Feed Quantities with Contract Requirements.

\begin{tabular}{|c|c|c|c|c|c|}
\hline \multirow{2}{*}{$\begin{array}{c}\text { Envelope } \\
\text {. }\end{array}$} & \multirow[t]{2}{*}{ Units } & \multicolumn{4}{|c|}{ Totals for Two Contractors } \\
\hline & & $\begin{array}{l}\text { Minimum envelope } \\
\text { order quantity }\end{array}$ & $\begin{array}{c}\text { Base case } \\
\text { delivered quanti }\end{array}$ & & $\begin{array}{l}\text { Maximum envelope } \\
\text { order quantity }\end{array}$ \\
\hline A & $\mathrm{MTNa}$ & 5,200 & 5,399 & $\leq$ & 9,800 \\
\hline B & $\mathrm{MTNa}$ & 200 & 234 & $\leq$ & 2,000 \\
\hline $\mathrm{C}$ & $\mathrm{MTNa}$ & 200 & 4,578 & $\leq$ & 4,800 \\
\hline $\mathrm{A}+\mathrm{B}+\mathrm{C}^{\prime}$ & $\mathrm{MTNa}$ & & $10,200^{2}$ & $s$ & $10,200^{2}$ \\
\hline
\end{tabular}




\begin{tabular}{|l|l|llll|}
\hline D & MTNVOL & 245 & 5 & 465 & $\leq 45$ \\
\hline
\end{tabular}

'There is a combined maximum order quantity limit for envelopes $A, B$, and $C$ that is less than the sum of the individual maximum order quantities.

'Rounded off

$\mathrm{LAW}=$ low-activity waste.

NVOL $=$ nonvolatile oxides less sodium and silicon.

$\mathrm{N} \mathrm{a}=$ sodium.

$\mathrm{MT}=$ metric tons.

\subsubsection{Developing Operating Scenarios}

The Phase 1 operating scenario is the equipment and activities necessary to mix, sample, transfer, stage, adjust, and deliver feed; to disposition immobilized low-activity waste (ILAW) and immobilized high-level waste (IHLW), and secondary wastes and returns; and to provide infrastructure support for the private contractors that process wastes. The scope of this operating scenario includes:

- Retrieve, prepare, and deliver both HLW and LAW feed within contract specifications

- $\quad$ Return to the DST system of entrained solids and separated ${ }^{90} \mathrm{Sr} /$ transuranic (TRU) waste from the private contractors

- Recieve ILAW for disposal

- Receive IHLW for interim storage

- $\quad$ Receive and manage waste from facility cleanout, salt well pumping, and retrieval of SSTs

This operating scenario was developed based on the steps listed below.

1. Applicable requirements from the private contracts and major enabling assumptions were identified (Enabling Assumptions list).

2. Specific DSTs that contain waste that would be used to satisfy the quantity and sequence requirements of the waste feed envelopes were identified; and the sequence of batches was established.

3. Delivery dates and process durations for each batch were determined to assure a steady supply of feed to the private contractors at the assumed processing rate.

4. Specific waste transfers and processing activities needed to prepare and deliver each batch of feed were established. 
5. Volume and timing of the IHLW, ILAW, entrained solids, and separated ${ }^{90} \mathrm{Sr} / \mathrm{TRU}$ waste from the private contractors were estimated based on contract requirements and flowsheet considerations.

6. The operating scenario was checked for consistency with contract requirements and enabling assumptions.

\section{Low-Activity Waste Feed}

The DOE developed the LAW feed envelope (A-C) composition requirements using process knowledge and available analytical data from all of the 177 tanks. The DOE intended that LAW feed could be provided from DSTs during Phase 1. For identifying feed source tanks, the best available tank characterization data was compared with envelope limits to target specific DST as feed tanks. Dilution water needed to retrieve and transfer the waste and the dissolution and/or precipitation of solids after dilution was considered in estimating compositions for the targeted waste. Laboratory process testing is being performed to confirm the dissolution behavior, transport properties; and composition of the targeted waste that is planned for delivery as feed.

The source tanks and the processing sequence was established consistent with privatization contract specifications. The selected tank sequence considered logistics whenever there was flexibility in meeting the contract requirements. These included consideration of tank usage and the operation waste volume projections, processing of more dilute waste first to free up tank space more quickly, and simplification of project design and construction schedule. Information for feed batches, volumes, and other aspects of the LAW feed operating scenario are presented in Table 5 .

\section{High-Level Waste Feed}

The DOE created the HLW feed envelope D specifications using process knowledge and analytical data from four source tanks: AZ-101, AZ-102, AY-102, and C-106. These tanks were selected as source tanks for HLW feed during Phase 1. Tank C-104 was also selected to provide the additional material needed to satisfy the maximum order quantity of HLW feed. Laboratory process testing is planned to confirm the chemical behavior, physical properties, transport properties, and composition of the pretreated sludge. The processing sequence was established as described for HLW feed. Table 6 shows the source of feed for each feed batch, the volume and quantity of feed available in the source tank, and the pre-staging tank if one is required.

\section{Feed Delivery System}

The feed delivery requirements were analyzed and used to select tanks that contained the desired feed envelope wastes. The equipment in these tanks was then evaluated to determine upgrade requirements to mobilize, adjust, and transfer the waste. In parallel, the associated transfer pipelines were evaluated to determine upgrades required to move the wastes to feed staging tanks. The planned private contractor processing rates were used to determine the timing for feed deliveries. A tank waste and transfer system simulation model (Kirkbride et al. 1997) was used for this planning. The required equipment upgrades are determined by comparing the existing system configuration and capability with the desired configuration and capability. 
Figure 5 shows two of the configurations required for feed delivery. The sequence of tanks and required upgrades to provide Phase 1 feed are presented in Figure 6.

Three projects provide the required feed delivery system upgrades. They include projects W-211, Initial Tank Retrieval Systems; $\backslash$ W-314, Tank Farm Restoration and Safe Operations; and W-TBD. These projects include the addition of mixer pumps (and other equipment necessary to mobilize the feed), transfer systems to move the feed to the staging tanks, and add in-tank sludge washing capability. Project W-TBD was scoped to include additional transfer systems and other equipment not provided by projects W-211 and W-314.

\section{Immobilized Low Activity Waste Disposal}

The volume of ILAW expected is controlted by the amount of waste treated and the allowable immobilized waste package volume-to-feed ratios. The three empty chambers of the TWRS grout vaults have been selected to receive the first approximately one third of the Phase I ILAW. Project W-465 is modifying the grout vaults to accept the ILAW packages.

A performance assessment has been drafted that will allow these vaults to be used for permanent on-site disposal of the ILAW. The decision was made to construct additional vaults (Project W-520) for the remainder of the ILAW from Phase 1. Figure 6 shows the timing of construction and operation of the required ILAW facilities.

The planned ILAW package capacity was compared with anticipated space needs based on waste processing assumptions. The planned facilities were found sufficient to house the ILAW under the planning case and two sensitivity cases (Figure 7). The TWRS Contractor is recommending that the ILAW vault (Project W-520) due to be available in 2005, be accelerated several months to avoid potential space conflicts (Section 5.5).

\section{Immobilized High-Level Waste Storage}

The Canister Storage Building under construction in the 200 Area by the Spent Nuclear Fuel Program will provide storage for IHLW produced during Phase 1. Two of the three compartments of the Canister Storage Building will be modified to house canisters of TWRS IHLW (Project W-464). The required IHLW storage capacity was determined by assuming that the maximum order quantity of waste would be processed and that the immobilized product would have the minimum ( $25 \mathrm{wt} \%$ nonvolatile oxides less sodium and silicon [NVOL]) Waste Oxide Loading specified in the contracts. This represents an upper bound on required IHLW storage capacity. Figure 8 shows that the Canister Storage Building capacity is consistent with the maximum expected number of IHLW canisters. Scheduling challenges caused by slips in the Spent Nuclear Fuel Program schedules are addressed in the risk list, and several viable mitigation options are available. Figure 6 shows the timing of modification and operation of the Canister Storage Building for IHLW storage. 
Table 5. Low-Activity Waste Source Tanks and Feed Batches.

\begin{tabular}{|c|c|c|c|c|c|c|c|c|c|c|c|c|c|c|c|c|c|}
\hline \multirow[b]{2}{*}{ Envelope } & \multirow[b]{2}{*}{ Batch } & \multicolumn{3}{|c|}{ Available feed ${ }^{a}$} & \multirow[b]{2}{*}{$\begin{array}{l}\text { Dilution water } \\
\text { (ML) }\end{array}$} & \multirow[b]{2}{*}{$\begin{array}{l}\text { Pre-stage tank } \\
\text { (static date) }\end{array}$} & \multicolumn{4}{|c|}{ Approximate timing ${ }^{b}$} & \multicolumn{4}{|c|}{ Feed delivered to each contractor } & \multirow[b]{2}{*}{ Batch - contractor } & \multicolumn{2}{|c|}{$\begin{array}{l}\text { Total feed delivered for both } \\
\text { contractors }^{\mathrm{g}}\end{array}$} \\
\hline & & $\begin{array}{l}\text { Source tank } \\
\text { (static date) }\end{array}$ & $\begin{array}{l}\text { Sodium } \\
\text { (MT) }\end{array}$ & $\begin{array}{l}\text { Volume } \\
\text { (ML) }\end{array}$ & & & $\begin{array}{c}\text { Start } \\
\text { retrievale }\end{array}$ & $\begin{array}{c}\text { Begin } \\
\text { staging }^{d}\end{array}$ & $\begin{array}{l}\text { Batch } \\
\text { ready }\end{array}$ & $\begin{array}{l}\text { Batch } \\
\text { delivered }^{f}\end{array}$ & $\begin{array}{l}\text { Sodium }{ }^{8} \\
\text { (MT) }\end{array}$ & $\begin{array}{l}\text { Volumes } \\
\text { (ML) }\end{array}$ & $\begin{array}{c}\text { Delivery } \\
\text { time } \\
\text { (days) }\end{array}$ & $\begin{array}{l}\text { Process } \\
\text { time }{ }^{\mathrm{b}, \mathrm{i}} \\
\text { (days) }\end{array}$ & & $\begin{array}{l}\text { Sodium } \\
(\mathrm{MT})\end{array}$ & $\begin{array}{l}\text { Volume } \\
(\mathrm{ML})\end{array}$ \\
\hline \multirow{11}{*}{ A } & \multirow{2}{*}{1} & \multirow{2}{*}{$\begin{array}{l}\text { AN-105 } \\
\text { (Now) }\end{array}$} & \multirow{2}{*}{1090} & \multirow{2}{*}{4.13} & \multirow{2}{*}{1.45} & \multirow[b]{2}{*}{ - } & \multirow{2}{*}{$3 / 2001$} & \multirow{2}{*}{$6 / 2001$} & $12 / 2001$ & $12 / 2001$ & 514 & 2.63 & 3.6 & 222 & $1-\mathrm{Cl}$ & \multirow{2}{*}{1,027} & \multirow{2}{*}{5.25} \\
\hline & & & & & & & & & $12 / 2001$ & $12 / 2001$ & 513 & 2.62 & 3.6 & 225 & $1 \cdot \mathrm{C} 2$ & & \\
\hline & \multirow{2}{*}{2} & \multirow{2}{*}{$\begin{array}{l}\text { AN-104 } \\
\text { (Now) }\end{array}$} & \multirow{2}{*}{1100} & \multirow{2}{*}{3.77} & \multirow{2}{*}{1.92} & \multirow{2}{*}{ - } & \multirow{2}{*}{$10 / 2001$} & & $6 / 2002$ & $1 / 2003$ & 535 & 2.77 & 3.8 & 266 & $2-\mathrm{Cl}$ & 1.070 & 5.54 \\
\hline & & & & & & & & $.12 / 2001$ & $6 / 2002$ & $1 / 2003$ & 535 & 2.77 & 3.8 & 266 & $2-\mathrm{C} 2$ & $1,0 / 0$ & 5.34 \\
\hline & 3 & AW-101 & 991 & 4.27 & 2.48 & - & $1 / 2003$ & $3 / 2003$ & $8 / 2003$ & $10 / 2003$ & 428 & 2.86 & 3.9 & 218 & $3-\mathrm{Cl}$ & 856 & 5.72 \\
\hline & 3 & (Now) & 991 & 4.21 & 2.40 & - & 172005 & 3/2003 & $9 / 2003$ & $10 / 2003$ & 428 & 2.86 & 3.9 & 218 & $3-\mathrm{C} 2$ & 800 & 3.12 \\
\hline & 4 & AN-103 & 1234 & 3.69 & 3.03 & - & $5 / 2003$ & $10 / 2003$ & $3 / 2004$ & $5 / 2004$ & 585 & 3.18 & 4.4 & 317 & $4-\mathrm{Cl}$ & 1,170 & 6.36 \\
\hline & 4 & (Now) & 1204 & 3.07 & 3.03 & - & $3 / 2003$ & $10 / 2003$ & $3 / 2004$ & $5 / 2004$ & 585 & 3.18 & 4.4 & 317 & $4-\mathrm{C} 2$ & 1,170 & 0.30 \\
\hline & & $\begin{array}{l}\text { AP-101 } \\
(4 / 1999) \\
\end{array}$ & 745 & 4.18 & 0.45 & & & & $10 / 2004$ & $3 / 2005$ & 575 & 2.87 & 3.9 & 288 & $5-\mathrm{Cl}$ & & \\
\hline & 5 & $\begin{array}{l}\text { AW-104 } \\
(10 / 1999)\end{array}$ & 491 & 3.83 & - & - & $5 / 2004$ & $5 / 2004$ & $11 / 2004$ & $3 / 2005$ & 701 & 3.51 & 4.8 & 351 & $5-\mathrm{C} 2$ & 1,276 & 6.38 \\
\hline & & Shim caustic & 380 & 0.87 & - & & & & & & & & & & & & \\
\hline & & AZ-101 & 359 & 3.12 & - & AY-101 & & & $8 / 2005$ & $1 / 2006$ & 118 & 1.05 & 1.4 & 59 & $6-\mathrm{Cl}$ & & \\
\hline B & 6 & A.Z-102 & 197 & 1.71 & - & $(1 / 2002)$ & $3 / 2003$ & $3 / 2005$ & $8 / 2005$ & $3 / 2006$ & 116 & 1.04 & 1.4 & 58 & $6-\mathrm{C}^{2}$ & 234 & 2.09 \\
\hline & $7^{\mathrm{h}}$ & & & & & & & & $1 / 2006$ & $3 / 2006$ & 119 & 0.74 & 1.0 & 29 & $7-\mathrm{Cl}$ & 238 & 1.48 \\
\hline & & AN-107 & 913 & 4.26 & $1.4 \mathrm{l}$ & - & $1 / 2006$ & 1/2006 & $3 / 2006$ & $5 / 2006$ & 119 & 0.74 & 1.0 & 29 & $7-\mathrm{C2}$ & 230 & 2.40 \\
\hline & $8^{\mathrm{h}}$ & $(11 / 1997)$ & & & & & & & $1 / 2006$ & $4 / 2006$ & 272 & 1.69 & 2.3 & 137 & $8-\mathrm{Cl}$ & 544 & 3.38 \\
\hline & & & & & & & & & $3 / 2006$ & $6 / 2006$ & 272 & 1.69 & 2.3 & 137 & $8-\mathrm{C} 2$ & 344 & \\
\hline & 9 & AN-102 & 1060 & 4.07 & 2.52 & - & $4 / 2006$ & $4 / 2006$ & $8 / 2006$ & $8 / 2006$ & 477 & 2.96 & 4.1 & 240 & $9-\mathrm{Cl}$ & 954 & 5.92 \\
\hline & & (Now) & 1000 & & 2.32 & - & 472000 & $4 / 2000$ & $10 / 2006$ & $10 / 2006$ & 477 & 2.96 & 4.1 & 240 & $9-\mathrm{C} 2$ & & \\
\hline C & 10 & AN-106 & 846 & 4.32 & 0.95 & - & $8 / 2006$ & $8 / 2006$ & $12 / 2006$ & $4 / 2007$ & 411 & 2.55 & 3.5 & 207 & $10-\mathrm{Cl}$ & 822 & 5.10 \\
\hline & & (7/1999) & & & & & & & $3 / 2007$ & $6 / 2007$ & 411 & 2.55 & 3.5 & 207 & $10-\mathrm{C} 2$ & & \\
\hline & 11 & SY-101 & 1390 & 4.28 & 4.37 & $\begin{array}{l}\text { AN-102 } \\
\text { AN-107 }\end{array}$ & $12 / 2005$ & $4 / 2007$ & $8 / 2007$ & $11 / 2007$ & 615 & 3.82 & 5.2 & 306 & $11-\mathrm{C} 1$ & 1,230 & 7.64 \\
\hline & & (Now) & . & & & $(5 / 2006)$ & & & $10 / 2007$ & 1/2008 & 615 & 3.82 & 5.2 & 306 & $11-C 2$ & & \\
\hline & 12 & SY-103 & 718 & 2.79 & 1.67 & $\begin{array}{l}\text { AN-102 } \\
\text { AN-107 }\end{array}$ & $12 / 2006$ & $11 / 2007$ & $3 / 2008$ & $9 / 2008$ & 452 & 2.81 & 3.8 & 256 & $12-\mathrm{C} 1$ & 789 & 4.90 \\
\hline & & (Now) & & & & $(3 / 2008)$ & & & $5 / 2008$ & $11 / 2008$ & 337 & 2.09 & 2.9 & 199 & $12-\mathrm{C} 2$ & & \\
\hline
\end{tabular}

"This "Available Feed" vilumes (before ediution) and quantity have not been reduced to account for the waste heels that will be left behind in the source tanks, pre-staging tanks, or staging tanks

"All dates are subject to change within the contract and CD limits. All dates and durations are based on a 2.0 MT Na/contractor/day processing rate (averaged over cach
"The "Start Retrieval" date is the earlier of (1) when waste is first removed from the source tanks or (2) when controlled degassing of waste in the watch-list tanks begins.

The "Batch Ready" date is when the feed is ready for transfer to the private contractors feed tanks (AP-106 or AP-108). The feed is qualified and is in AP-102 and AP-104.

"The batch is delivered when 30-days of feed remain in the contractor's feed tanks (AP-106 or AP-108).

"The delivered quantity takes into account tank heels, dissolution of and separation of solids and mass balances.

"Proces Tim" sho be

fred tanks between feed batches of the same envelope.

The term "static" is used to define whe
ICD = Interffoch

$\mathrm{Mr}=$ metric ton $\quad \mathrm{ML}=$ nillion liters

$\mathrm{Na}=$ sodium 
Table 6. High-Level Waste Source Tanks and Feed Batches.

\begin{tabular}{|c|c|c|c|c|c|c|c|c|c|c|c|c|c|c|c|c|c|}
\hline \multirow{2}{*}{ Envelope } & \multirow{2}{*}{ Batch } & \multicolumn{3}{|c|}{ Available feed ${ }^{2}$} & \multirow{2}{*}{$\begin{array}{l}\text { Sluicing } \\
\text { receiver }\end{array}$} & \multirow{2}{*}{$\begin{array}{l}\text { Washing and } \\
\text { staging tank }\end{array}$} & \multicolumn{5}{|c|}{ Approximate timing ${ }^{b}$} & \multicolumn{2}{|c|}{$\begin{array}{l}\text { Total feed delivered from } \\
\text { source tank }\end{array}$} & \multicolumn{2}{|c|}{$\begin{array}{l}\text { Feed delivered } \\
\text { per batch }\end{array}$} & \multicolumn{2}{|c|}{$\begin{array}{l}\text { Feed delivered to } \\
\text { immobilization }\end{array}$} \\
\hline & & $\begin{array}{c}\text { Source } \\
\text { tank }\end{array}$ & $\begin{array}{l}\text { Quantity }^{\circ} \\
\text { (MT) }\end{array}$ & $\begin{array}{c}\text { Volume } \\
\text { (ML) }\end{array}$ & & & $\begin{array}{c}\text { Begin } \\
\text { sluicing }\end{array}$ & $\begin{array}{l}\text { Begin pre- } \\
\text { stagings }\end{array}$ & $\begin{array}{c}\text { Begin } \\
\text { conditioning }\end{array}$ & $\begin{array}{l}\text { Batch } \\
\text { ready }\end{array}$ & $\begin{array}{c}\text { Batch } \\
\text { delivered }\end{array}$ & $\begin{array}{l}\text { Quantity } \\
\text { (MT) }\end{array}$ & $\begin{array}{l}\text { Volume } \\
\text { (ML) }\end{array}$ & $\begin{array}{c}\text { Quantity } \\
\text { (MT) }\end{array}$ & $\begin{array}{c}\text { Volume } \\
\text { (ML) }\end{array}$ & $\begin{array}{c}\text { Delivery } \\
\text { time (days) }\end{array}$ & $\begin{array}{c}\text { Process } \\
\text { time (days) }\end{array}$ \\
\hline \multirow{12}{*}{ D } & 1 & \multirow{2}{*}{$A Z-101$} & \multirow{2}{*}{96.4} & \multirow{2}{*}{0.18} & \multirow{2}{*}{ - } & \multirow{2}{*}{ AZ-101 } & & & \multirow{2}{*}{$10 / 2000$} & \multirow{2}{*}{$8 / 2001$} & $5 / 2002$ & \multirow{2}{*}{86.8} & \multirow{2}{*}{1.06} & 43.4 & 0.53 & 1 & 264 \\
\hline & 2 & & & & & & & - & & & $2 / 2003$ & & & 43.4 & 0.53 & 1 & 264 \\
\hline & 3 & \multirow{2}{*}{$A Z-102$} & \multirow{2}{*}{161.5} & \multirow{2}{*}{0.39} & \multirow{2}{*}{ - } & \multirow{2}{*}{ AZ-102 } & \multirow{2}{*}{ - } & \multirow{2}{*}{ - } & \multirow{2}{*}{$4 / 2002$} & \multirow{2}{*}{$2 / 2003$} & $11 / 2003$ & \multirow{2}{*}{97.0} & \multirow{2}{*}{1.10} & 48.5 & 0.55 & 1 & 295 \\
\hline & 4 & & & & & & & & & & $8 / 2004$ & & & 48.5 & 0.55 & 1 & 295 \\
\hline & 5 & \multirow{3}{*}{$A Y-102$} & \multirow{3}{*}{37.5} & \multirow{3}{*}{0.08} & & & & & & & $6 / 2005$ & & & 32.9 & 0.49 & 1 & 200 \\
\hline & 6 & & & & & & & & & & $1 / 2006$ & & & 32.9 & 0.49 & 1 & 200 \\
\hline & 7 & & & & AY- 102 & $A Z-101$ & $10 / 1998$ & $6 / 2003$ & $6 / 2003$ & $4 / 2004$ & $7 / 2006$ & 165 & 2.45 & 32.9 & 0.49 & 1 & 200 \\
\hline & 8 & C-106 & 156.3 & 0.75 & & & & & & & $2 / 2007$ & & & 32.9 & 0.49 & 1 & 200 \\
\hline & 9 & & & & & & & & & & $8 / 2007$ & & & 32.9 & 0.49 & 1 & 200 \\
\hline & 10 & & & & & & & & & & $3 / 2008$ & & & 46.9 & 0.54 & 1 & 285 \\
\hline & 11 & $\mathrm{C}-104$ & 386.0 & 1.12 & AY-102 & $A Z-102$ & $7 / 2004$ & $7 / 2005$ & $7 / 2005$ & $5 / 2006$ & $12 / 2008$ & 117 & 1.35 & 46.9 & 0.54 & 1 & 285 \\
\hline & 12 & & & & & & & & & & $10 / 2009$ & & & 23.5 & 0.27 & 1 & 143 \\
\hline
\end{tabular}

"The "Available Feed" volumes and quantities have not been reduced to account for the waste heels that will be leff behind in the source tanks, pre-staging tanks, or staging tanks.
"All dates are subjcct to change within the contract and ICD limits. All dates and durations are based on a 0.164 MT NVOL/day processing rate (averaged over each individual feed batch).

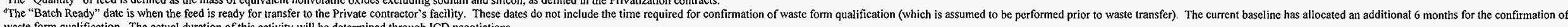
•Processing times are based on an assumed immobilization facility processing rate of 0.164 MT of equivalent nonvolatitic oxides per day.

ICD = Interface Control Document

$M T=$ metric ton

$\mathrm{ML}=$ million liters
$\mathrm{NVOL}=$ nonvolatile 

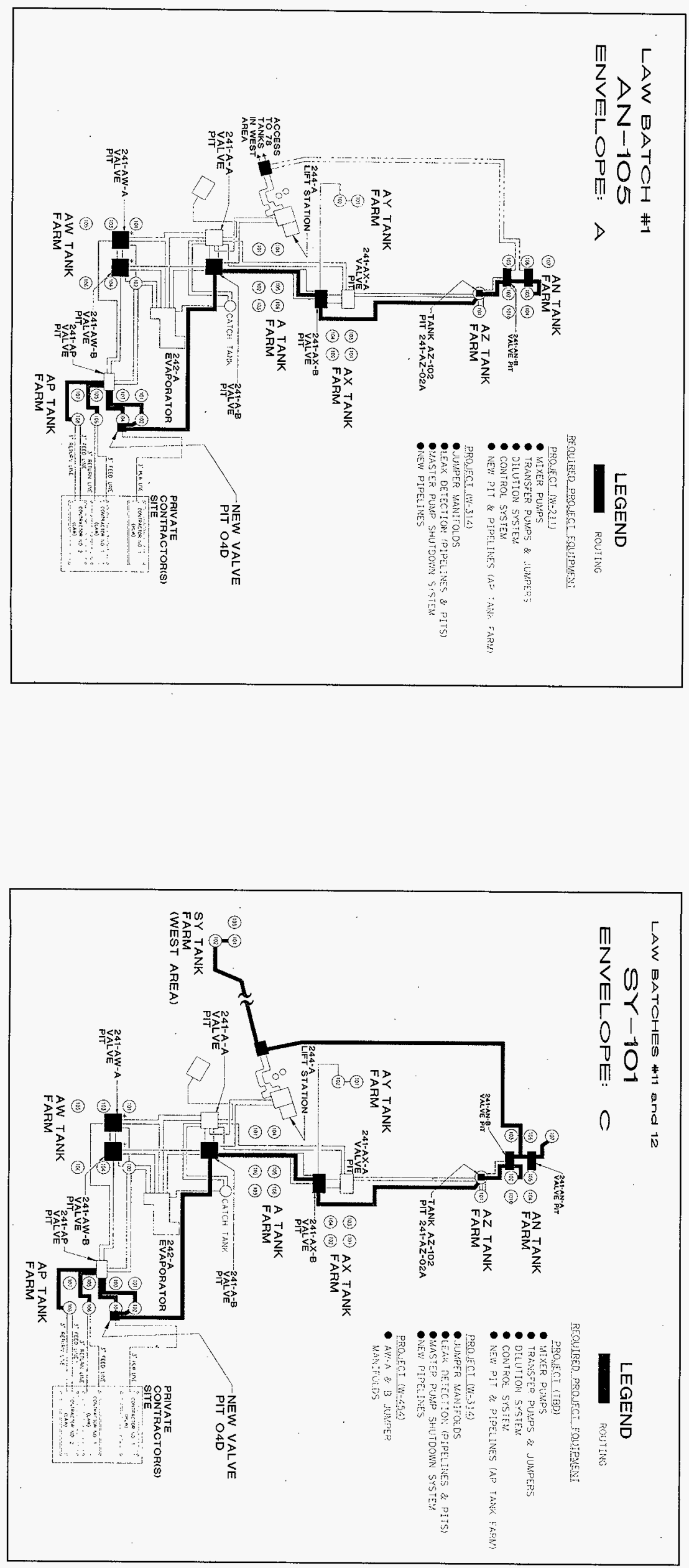

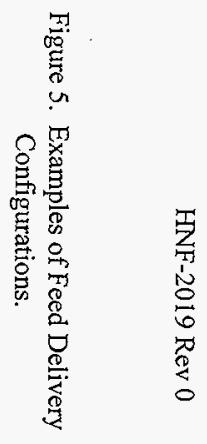




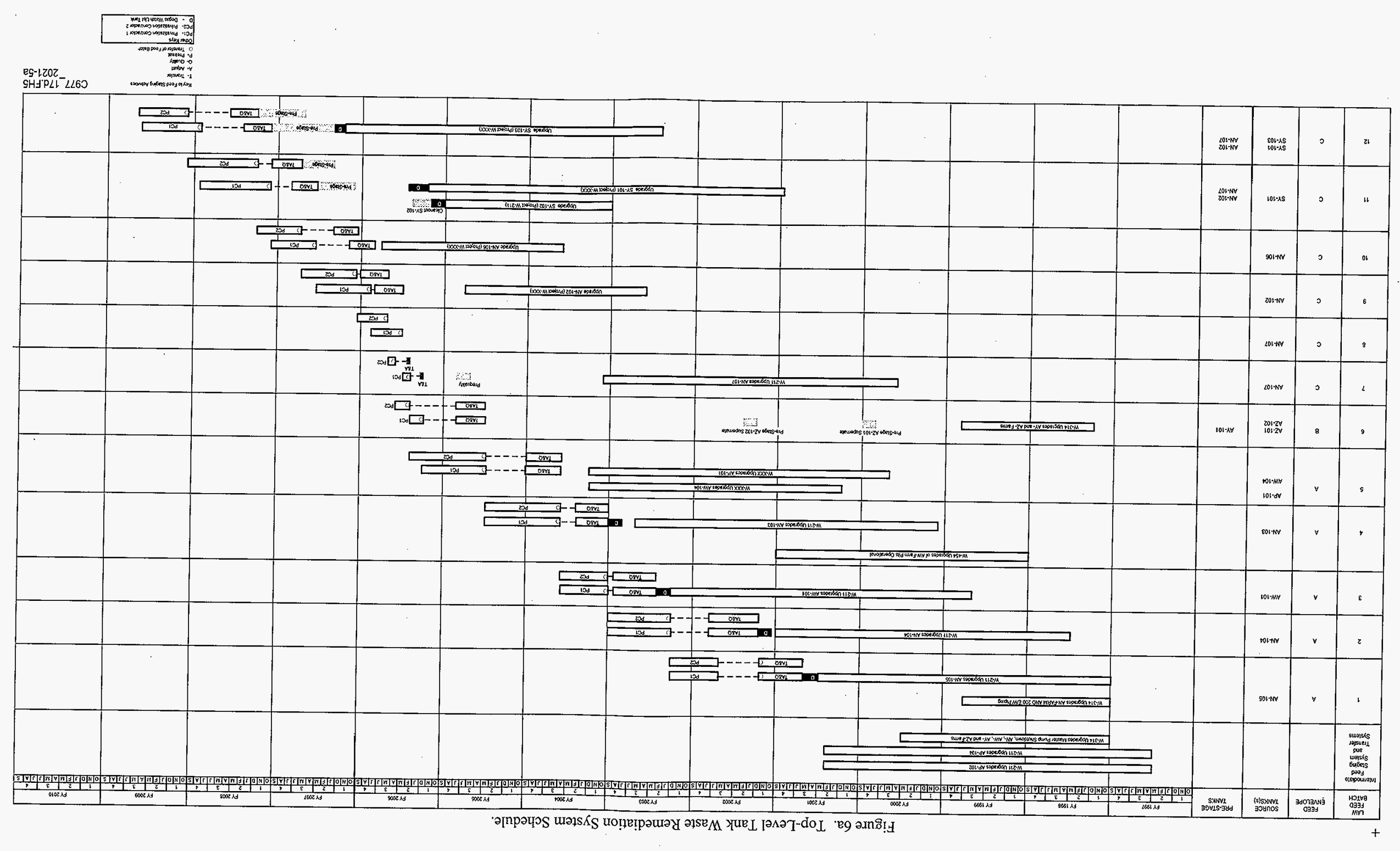

0 ควУ $6 \mathrm{IOZ}-\mathrm{ANH}$ 
Figure 6b. Top-Level Tank Waste Remediation System Schedule.
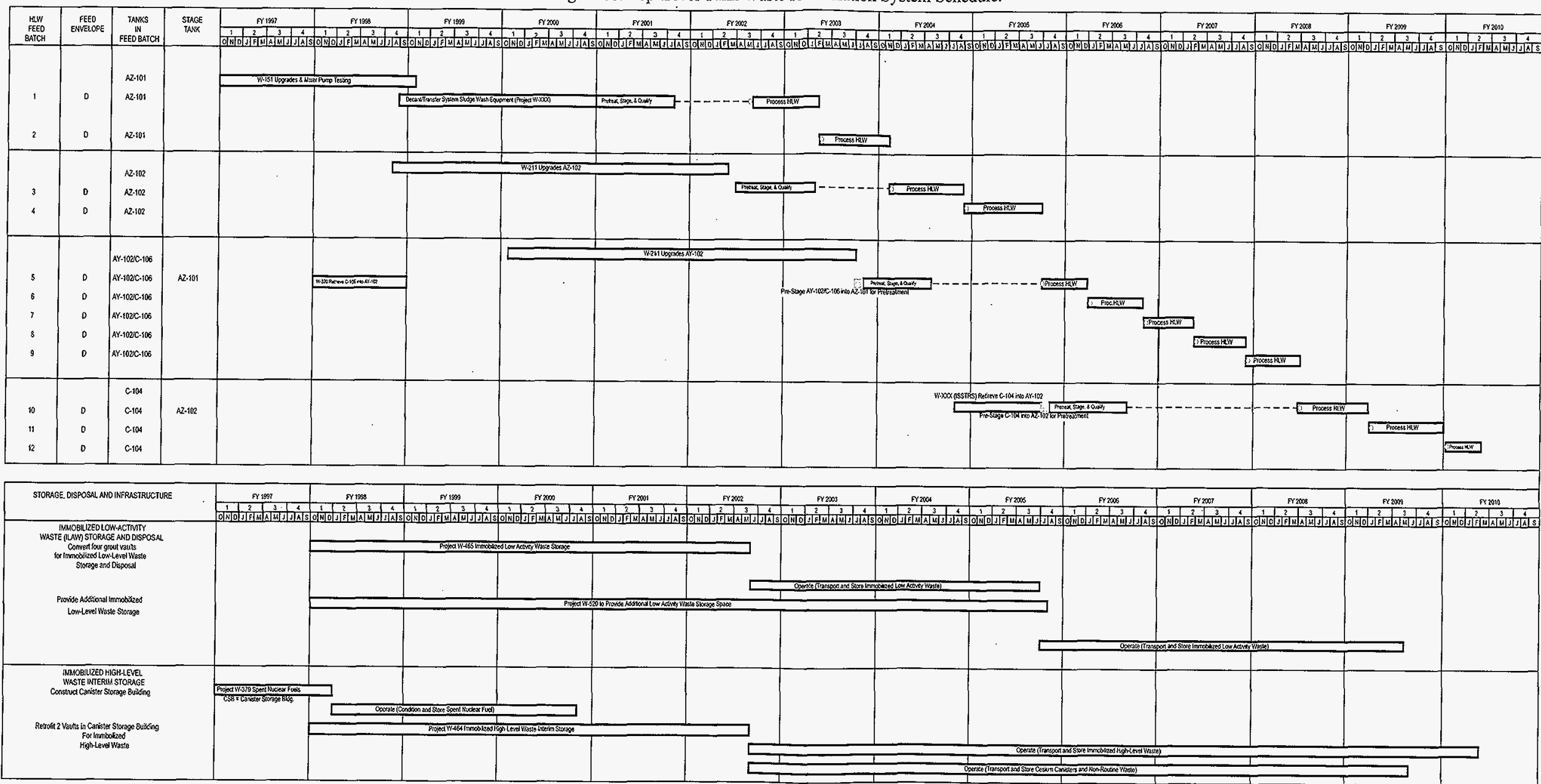
Figure 7. Immobilized Low-Activity Waste Storage and Disposal.

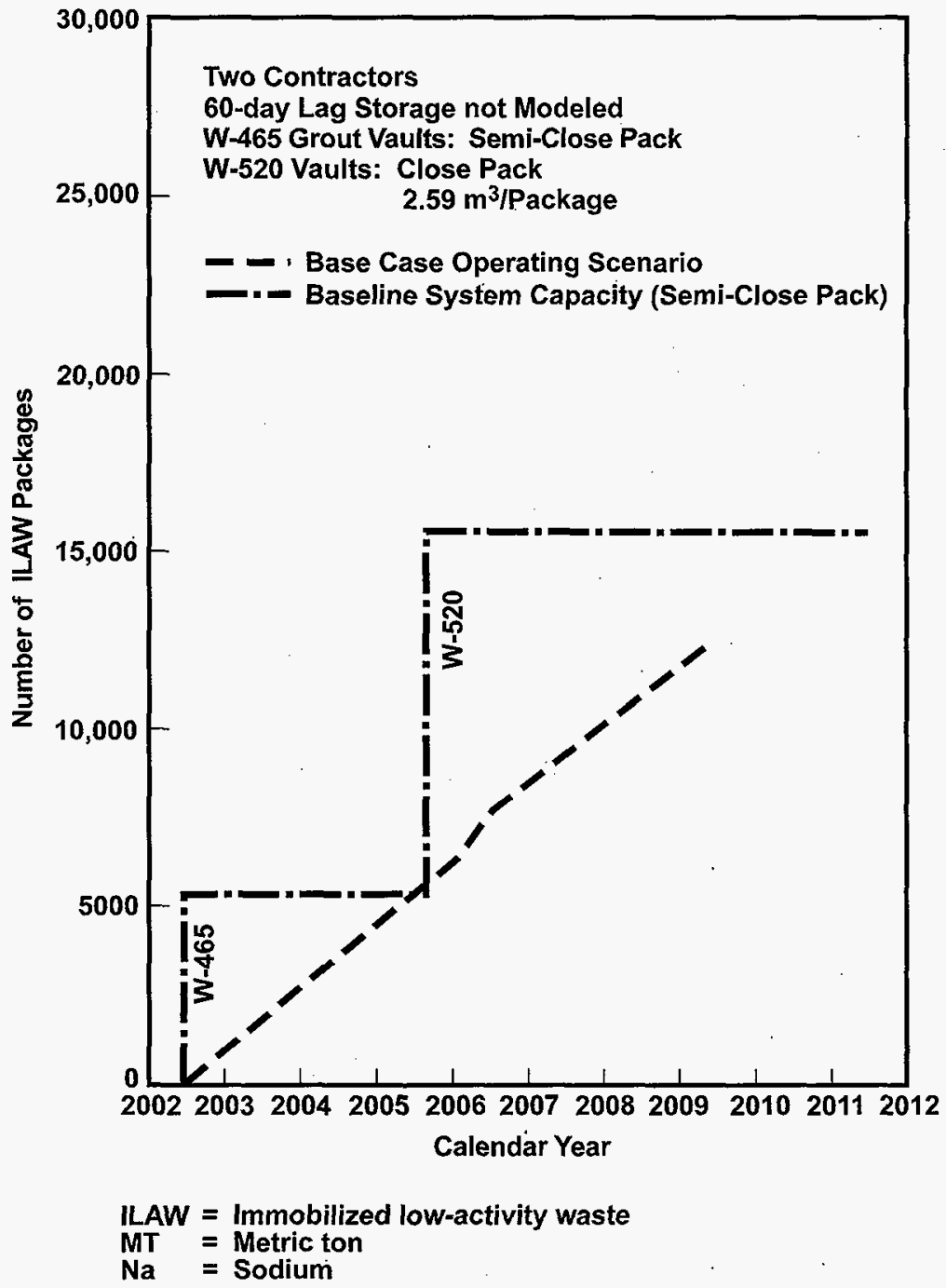


Figure 8. Immobilized High-Level Waste Exploratory Analysis.

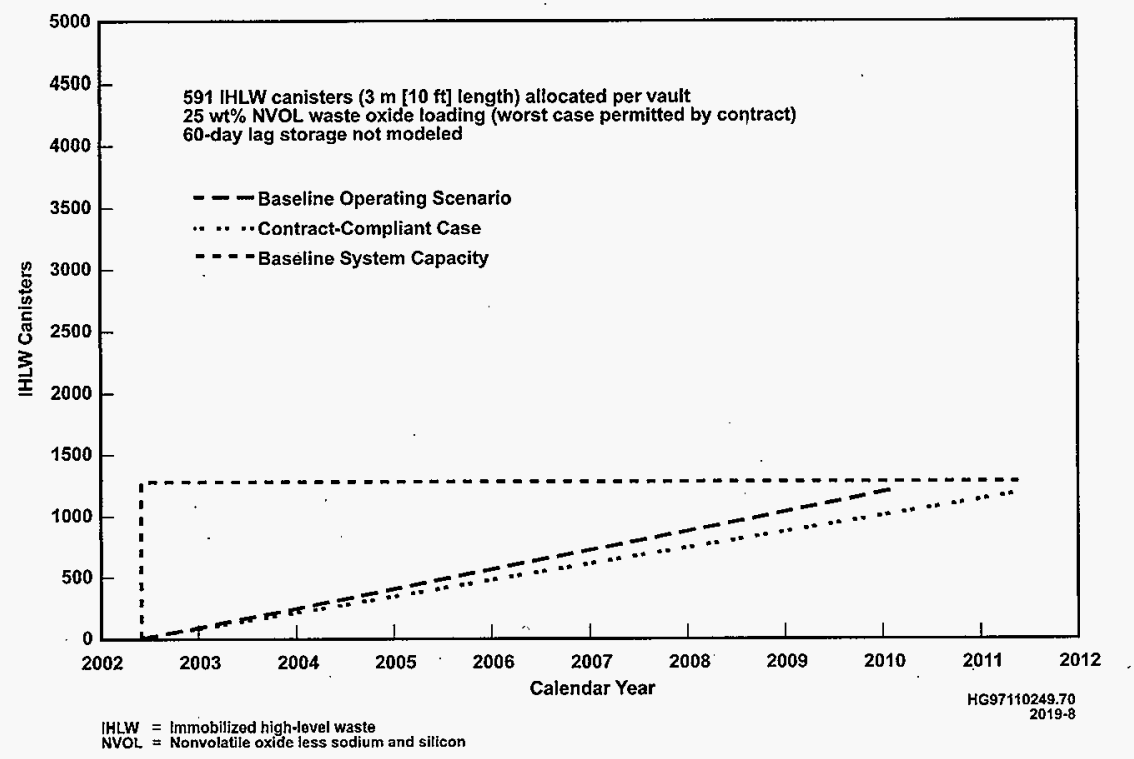

\subsubsection{Infrastructure Support to Private Contractors and Other Interfaces}

The DOE contract with the private contractors for immobilization requires the M\&I Contractor to provide tank space to accept the returned "Entrained Solids and Separated ${ }^{90} \mathrm{Sr}$ /TRU"; accept by-products and various secondary waste streams; provide land, water, and electricity for the private immobilization facilities; and provide other activities as specified. These interfaces are the subject of 19 draft ICDs (see Table 7). The draft ICDs are under configuration management and will be made final when the Phase $1 \mathrm{~B}$ contracts are placed.

Project W-519 provides utilities (raw and potable water, electrical and effluent transfer lines) and roads and site development work to support the infrastructure needs of the private contractors for Phase 1. The M\&I Contractor has confirmed that support and services (e.g., secondary waste treatment) provided by members of the PHMC team outside of the TWRS Project are planned consistent with the scope, schedule, and cost in the TWRS baseline, and that clear lines of communication and interface controls exist. 
HNF-2019 Rev 0

Table 7. Interface Control Documents Between TWRS Retrieval and Disposal Program and Private Contractors.

\begin{tabular}{|ll|}
\hline ICD \# & \\
\hline ICD-01 & Phase 1 Privatization - Raw Water \\
ICD-02 & Phase 1 Privatization - Potable Water \\
ICD-03 & Radioactive Solid Waste \\
ICD-05 & Non-Radioactive, Non-Dangerous Liquid Effluent for Phase 1 Privatization \\
ICD-06 & Radioactive Dangerous Liquid Effluents \\
ICD-09 & Land for Siting Part A Privatization \\
ICD-10 & Deactivated Facility and Site for Phase 1 Privatization \\
ICD-11 & Electricity \\
ICD-12 & Phase 1 Privatization Roads and Rail \\
ICD-13 & Phase 1 Privatization - Non-Routine High-Level Solid Wastes \\
ICD-14 & Phase 1 Privatization - Immobilized High-Level Waste Product \\
ICD-15 & Phase 1 Privatization - Immobilized Low-Activity Waste Product \\
ICD-16 & Phase 1 Privatization Strontium/Transuranic/Entrained Solids \\
ICD-17 & Phase 1 Privatization - Cesium-137 Intermediate Product \\
ICD-18 & Phase 1 Privatization ${ }^{99}$ Technetium Secondary Product \\
ICD-19 & Low-Activity Waste Feed \\
ICD-20 & Phase 1 Privatization - High-Level Waste Feed \\
ICD-21 & Phase 1 Waste Feed Tank Support Systems \\
ICD-22 & Air Emissions \\
\hline
\end{tabular}

'Compilation of Interface Control Documents, Recommendations to Resolve Open Issues, Plans to Resolve All Remaining Interface Issues, July 1997, HNF-SP-1227 (FDH 1997a); Individual documents listed in reference list to Program Plan as FDH 1997e-w.

ICD $=$ Interface Control Document.

NOTE: ICD numbers 04,07 , and 08 do not involve interfaces between the private contractors and the PHMC team.

\subsubsection{Summary of Technical Plans}

The operating scenario provides waste feed and infrastructure support and dispositions immobilized waste products consistent with technical requirements. A critical path schedule has been established, and the required systems, staff, and documentation are either in place or plans have been developed to ensure they will exist when needed. Existing plans confirm that the TWRS Contractor will be able to sustain feed delivery, infrastructure support, and receipt of 
HNF-2019 Rev 0

immobilized and other waste products for the duration of Phase 1 (i.e., through FY 2011) consistent with specifications (including maximum order quantities of waste) in the existing DOE contracts with the private contractors.

\subsection{MANAGEMENT APPROACH}

The Tank Waste Remediation System Program Plan (Freeman 1998) provides summary information for mission; technical approach; organization; WBS; milestone; schedule; environmental, safety, and health; quality assurance; policies; decision-making processes; and procedures that apply to the TWRS Retrieval and Disposal Mission. Included in the Program Plan is a description of the LMHC planning and implementation process. Ownership, sponsorship, and continuous improvement are key elements of the plan.

\section{Project Management and Operations}

DOE selected the PHMC Team recognizing that their commercial expertise would improve TWRS project management and provide a sound basis of support for the "privatization" effort. Parent companies (particularly Fluor Daniel and Lockheed Martin) of the PHMC team contractors are world-class enterprises that successfully compete for and execute fixed-price contracts in the global market. Lockheed Martin has annual sales of $\$ 35$ billion dollars and has had decades of success working to fixed-price contracts. Lockheed Martin's overall theme of mission success is based on completing products on time and within budget, to a level of quality that exceeds customers' expectations. The PHMC team has brought this expertise and discipline to the Hanford Site and has been restructuring the management culture, policies, and procedures to parallel those successfully used in commercial enterprises. This is discussed further in the Management Assessment (Payne et al. 1998).

Upon assumption of responsibility for the TWRS Project, LMHC conducted a management assessment of programs. LMHC found that programs generally lacked elements required for success. Program technical cost and schedule baselines were built on an incomplete set of technical, safety, and operational requirements. A full set of life-cycle functional requirements (such as constructability, operability, maintainability, reliability, etc.) was lacking. The nuclear safety authorization basis and plans were out-of-date with the tank farms authorization basis. Clear lines of communication and accountability were weak. This lack of specificity resulted in scope creep, schedule delays, and cost overruns. As these projects were corrected and rebaselined, lessons learned were developed and applied to TWRS Project planning and management processes.

The TWRS Contractor, with the assistance of its FDH Project Direction Team, has strived to establish the U.S. Department of Defense mentality for fixed price contracting for the TWRS Project baselines. LMHC is well into the process of changing the culture of the TWRS Project to bring it into line with best commercial practices. Rigorous planning and management, effective management systems, dedicated and qualified staff, and ownership and commitment at all levels are fundamental to the success of the TWRS Project. 
Established financial controls, effective project management tools, rigorous baseline management, strong leadership, and employee involvement is producing positive results. Recent successful examples include the nearly $\$ 50$ million cross-site transfer pipeline. This project was completed on time and on budget. This is early evidence of the cultural change underway that will allow successful execution of the Retrieval and Disposal Mission, Phase 1.

The TWRS Contractor has drawn upon lessons learned from successful ventures, as well as difficulties in large, complex projects conducted for the government or the private sector. The TWRS Project staff has incorporated many lessons from Savannah River's Defense Waste Processing Facility and Pit 9 at the Idaho National Engineering and Environmental Laboratory. Members of the PHMC team are familiar with both projects and recognize the difficulties associated with processing this waste. Previous efforts to deal with the Hanford Site tank waste were derailed by technical and policy challenges. The lessons from these efforts have been incorporated into the planning, execution, and risk management for the TWRS Project.

The TWRS Contractor is able to execute Phase 1. The TWRS Project has a mature and compliant Operations organization. Operations, maintenance, and engineering staffs are fully qualified and trained. Management systems and procedures are in place and ready to support the Phase 1 Mission. Activities similar to those necessary to support Phase $1 \mathrm{~B}$ are conducted on a routine basis. The maturity of the operations and programs are supported by favorable trends in performance indicators and the conclusions from a series of independent assessments and Operations Readiness Reviews. Since mid-1996 three performance-based assessments of the TWRS facilities have been completed by the Hanford Site Facility Evaluation Board. These independent assessments are designed to provide a thorough, accurate, and independent measure of performance. The assessments are structured similar to those conduced by the Institute of Nuclear Power Operators and the U.S. Navy Nuclear Program. Each Facility Evaluation Board was better than the previous demonstrating continuous improvement. The conclusions from the last Facility Evaluation Board assessments were that the TWRS facilities were operated safely and in compliance with requirements. Especially significant has been the steady improvement in Facility Evaluation Board examination ratings (see Payne et al. 1998 for additional discussion).

The TWRS Project has implemented rigorous safety and licensing policies and procedures that are patterned after nuclear industry requirements and fully comply with the applicable DOE orders. The Authorization Basis has been upgraded with the approval of HNF-SD-WM-BIO-001, Tank Waste Remediation System Basis for Interim Operation (BIO) (FDH 1997). The BIO provides the framework for future amendments to authorize the retrieval and storage activities.

Figure 9 depicts the overall process used to plan and complete work in TWRS facilities. This system is patterned after the general guidance contained in the Defense Nuclear Facilities Safety Board Technical Report Number 16 on "Integrated Safety Management." First, the workscope for each activity is clearly defined and requirements for safe performance are developed by integrating the safety elements. Next, the hazards associated with performing the work are analyzed, and controls to mitigate or prevent the hazards are developed and included in the work package. Finally, the work is conducted in accordance with the work package, and 
Figure 9. Process Used to Plan and Complete Work.

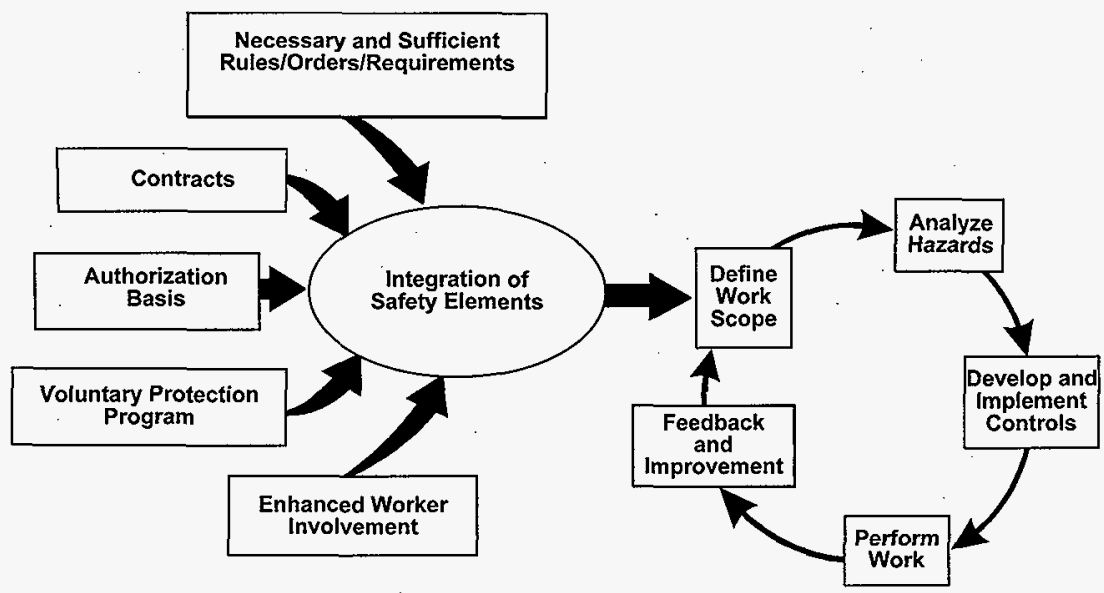

HG97110249.42

$2019-9$

improvement suggestions are fed back into the preparation of the future work packages. This integrated safety management system is described in greater detail in the BIO (FDH 1997), the WHC-SD-WM-PLN-1 14, TWRS Safety Management System Plan (Popielarczyk 1996), and the WHC-SD-HSP-002, Tank Farm Health and Safety Plan (Mickle 1995). These documents contain or reference the associated implementing procedures.

Trends in industrial and occupational safety performance for the TWRS Project are outstanding. Over the last year, the lost workday case rate has been reduced by $68 \%$ (below FY 1996 rates) from 0.72 to 0.23 per 200,000 man hours. These rates are well below the national average for similar work and are below the goals and actual performance levels set by the Institute of Nuclear Power Operators for nuclear utilities. The Institute of Nuclear Power Operators goals for lost work day case rates for the year 2000 are 0.4 per 200,000 hrs. A strong commitment to the voluntary protection program and integrated safety management systems approach (Mickle 1995) will provide the framework for a safe execution of the TWRS Retrieval and Disposal Mission.

\subsection{ASSUMPTIONS, RISKS, AND RECOMMENDATIONS}

Assumptions are required to enable planning. All planning assumptions have been documented as part of the technical or program baseline and managed (tracked, controlled, and validated) to support a defensible planning foundation. The major assumptions are discussed in the following sections and provided in Baldwin et al. (1998). The risk of adverse impacts to 
project cost, schedule, and technical performance arise from sources both internal and external to the TWRS Project. Risks have been identified and mitigation plans have been incorporated into the technical and program baselines. The major remaining risks are being tracked and managed. These major risks are discussed in the following sections and presented in Attachment 1 . The TWRS Contractor has developed recommendations that decrease risk to this clean up enterprise. Attachment 1 provides a table that presents the major assumptions, risks, mitigation actions, and recommendations.

\subsubsection{Major Assumptions}

Assumptions are made at every level of planning. The Enabling Assumptions List (Baldwin et al. 1998) provides the major assumptions that enable planning for the TWRS Retrieval and Disposal Mission. Planning guidance (e.g., assume waste processing will start in June 2002) provided by the customer (DOE) is used in developing the program baseline. Such fundamental assumptions are subject to change (e.g., during Phase 1B contract negotiation in the spring of 1998). Changes to these assumptions require changes to the TWRS Retrieval and Disposal Mission and result in changes in costs, schedule, and risk. The DOE may elect to make such changes to reduce the risk of the TWRS Retrieval and Disposal Mission or to provide more favorable performance (cost, schedule, technical) for the taxpayer. The TWRS Contractor has developed the planning detail and analytic tools (e.g., waste transfer simulation models) that allow rapid evaluation of the impacts of changes to the planning base on program cost, schedule, technical performance, and risk.

The TWRS Contractor has derived some planning assumptions from specifications in the DOE contracts with the private contractors for the immobilization phase. For example, the contracts call for the private contractors to "demonstrate a minimum system capacity of 600 metric tons (MT) sodium (Na) over a 12-month period". That requirement was the basis for the TWRS Contractor to derive a 2 MT Na per day (600 MT roughly divided by 365 days in a 12 -month period) processing rate. The feed delivery calculations for LAW were then based on the envelope specifications and maximum order quantities to be delivered to the private contractors to support a $2 \mathrm{MT}$ Na per day LAW processing rate. Because the TWRS Contractor does not yet know when and how fast the private contractors will require LAW feed, this enabling assumption allowed planning to proceed. This assumption allows the private contractors to meet the "LAW processing rate" requirement at any time during Phase 1 . As is the case for other basic planning assumptions, this assumption has been shared with $\mathrm{DOE}$, but cannot be validated until the final Phase 1 contracts are in place.

Other planning assumptions have been developed by the TWRS Contractor and are generally technical in nature (e.g., adequate quantities of waste feed is available to meet contract requirements; the 200-horsepower mixer pumps planned for waste mixing and mobilization will be adequate; feed delivery activities can be accommodated by planned amendments to the TWRS authorization basis ). These assumptions have a solid technical foundation, but also have some finite probability of being proven wrong (i.e., an associated risk to cost, schedule, or technical 
performance). Mitigation actions have been identified for the risks associated with these assumptions.

\subsubsection{Major Risks}

The TWRS Contractors have identified the primary uncertainties and risks that must be managed to successfully carry out the TWRS Retrieval and Disposal Mission for Phase 1 (Zimmerman 1998a). The list of critical risks (Attachment 1) was created from a variety of TWRS programmatic and technical source documents, primary among them is the TBR data packages discussed in Section 4.2.3. The TBRs identified risk at Level 8 of the WBS, providing a bottoms-up evaluation of risks. Risks were also identified by considering upper-level planning assumptions to provide a more comprehensive set of critical risks. Other sources for risk identification were the independent risk analysis (conducted as part of the Financial Analysis), the RTP internal independent review (Schaus 1997), and existing TWRS Project risk lists.

Risks arise from uncertainties in technical assumptions or performance (e.g., sufficient waste exists to meet feed delivery requirements); estimates of cost and schedule; and understanding or changes in programmatic (i.e., coming through DOE) policies, procedures, guidance, and requirements. The consequences of the adverse events resulting from these uncertainties result in cost, schedule, or technical performance impacts.

As risks were identified, mitigation actions (e.g., conducting additional tests before proceeding, providing spare parts, modifying equipment) were developed and incorporated into the baseline plans. The goal was to reduce the manageable significant risk to an acceptable level for success of the TWRS Project. The risk management process is presented in the TWRS Risk Management Procedure (Zimmerman 1998a) and in the Financial Analysis (Wells 1998). Programmatic risks of a programmatic nature arise from changes in requirements, policies, and procedures from DOE or sources outside of the TWRS Project. These risks cannot be readily estimated or predicted, therefore management of programmatic risk is difficult. Good communications (with the customer and stakeholders) and solid technical and management foundations are the best defense against impacts associated with risks.

\section{Summary of Retrieval and Disposal Mission Risk}

Overall, there is a modest level of risk associated with the TWRS Retrieval and Disposal baseline. The level of technical uncertainty is low because (1) most of the operations and facilities needed either exist or are well understood, (2) contingencies have been incorporated into technical operations (e.g., the ability to blend or adjust waste feed to meet envelope specifications), and (3) no new technology breakthroughs are required and much of the technical work is simple construction and operation. The technical uncertainties do appear on the list and are being rigorously managed (e.g., mixer pump performance, required modifications to the authorization basis). These technical risks, however, are manageable. 
Schedule delay is the primary source of risk for the TWRS Retrieval and Disposal Mission. For example, Waste Feed Delivery's ability to recover from a pump failure is predicated on how quickly a pump can be replaced and/or whether an alternative waste transfer route or alternative source of tank waste can be used. Availability of storage space for the IHLW canisters is potentially at risk because of schedule delays in the operation of the Canister Storage Building. Management issues are a source of technical risk (e.g., the ability to simultaneously install multiple retrieval systems in the Tank Farms without logistic breakdowns). The management related risks can be mitigated by effective management and work management systems (see Section 5.4). The planning and systems to avoid schedule delays are in place and additional improvements are planned.

TWRS Project schedules include float but will require close attention. The DOE needs to be cognizant of the TWRS Contractor's planning assumptions and help to manage changes in contract specifications, policies, and procedures to avoid changes that would result in cost and schedule impacts for the TWRS Retrieval and Disposal Mission baseline or create technical challenges that cannot be handled within the bounds of Phase 1 .

The cost-related risk is considered to be relatively low (see Wells 1998) because a history of the cost of operations, equipment, and construction exist and a reasonable level of conservatism has been built into the initial cost estimates of the activities identified at Level 8 and summarized to Level 7 of the WBS. The Financial Analysis identified a relatively small increment of additional funding required to raise the confidence level to an 80 percent likelihood of achieving the workscope activities within cost and schedule targets.

Planning assumptions have associated risk and are a major contributor to uncertainty. The primary risks were cross walked to the set of Key Enabling Assumptions on the Critical Risk List (Attachment 1).

\subsubsection{Recommendations for Reducing Risk and Cost}

Through the development of the baseline and the evaluation of risks, a number of opportunities have been identified for reducing cost and risk. Recommendations associated with major risks or assumptions are presented in the Critical Risk List (Attachment 1). More information on recommendations for reducing cost and risk associated with the TWRS Retrieval and Disposal Mission are provided in the Tank Waste Remediation System Operation and Utilization Plan (Kirkbride et al. 1997). The RTP Management Assessment (Payne et al. 1998) provides recommendations for improving the cost and risk profile for both Phase 1 and Phase 2 components of the mission. The PHMC team is committed to the success of the privatization effort and will continue to seek opportunities to work with DOE and the private contractors to promote the success of the TWRS Project. 
HNF-2019 Rev 0

\subsection{REFERENCES}

Acts

Nuclear Waste Policy Act of, as amended, 42 USC 10101 et seq.

Resource Conservation and Recovery Act of 1976, as amended, 42 USC 6901 et seq.

\section{Federal Register}

62 FR 8693, 1997, "Record of Decision for the Tank Waste Remediation System, Hanford Site, Richland, WA," Federal Register, Vol. 62, pp. 8693-8704 (February 26).

\section{Department of Energy Orders}

DOE Order 425.1, Startup and Restart of Nuclear Facilities, U.S. Department of Energy, Washington, D.C.

DOE Order 430.1, Life Cycle Asset Management, U.S. Department of Energy, Washington, D.C.

\section{Good Practice Guides}

GPG-FM-002, Critical Decision Criteria, U.S. Department of Energy, Washington, D.C.

\section{Logic Diagrams}

FDH, 1998, Logic Diagrams, prepared by Lockheed Martin Hanford Corporation for Fluor Daniel Hanford, Inc., Richland, Washington.

- H-2-823148, TWRS Retrieval Level 1 Logic Immobilized Waste (ILAW)

- $\quad$ H-2-829149, TWRS Retrieval Level 1 Logic Immobilized Waste (IHLW)

- $\quad$ H-2-829150, TWRS Retrieval Level 1 Logic Infrastructure Phase 1 Privatization Support

- $\quad$ H-2-892151, TWRS Retrieval Level 1 Logic Waste Feed Delivery LAW 1st Feed Batches Tank AN-105

- H-2-829152, TWRS Retrieval Level 1 Logic Waste Feed Delivery LAW 2nd Feed Batches Tank AN-104

- $\quad$ H-2-829153, TWRS Retrieval Level I Logic Waste Feed Delivery LAW 3rd Feed Batches Tank AW-101 
- H-2-829154, TWRS Retrieval Level 1 Logic Waste Feed Delivery LAW 4th Feed Batches Tank $A N-103$

- H-2-829155, TWRS Retrieval Level 1 Logic Waste Feed Delivery LAW 5th Feed Batches Tanks AP-101 \& AW-104

- $\quad$ H-2-829156, TWRS Retrieval Level 1 Logic Waste Feed Delivery LAW 6th Feed Batches Tank AY-101

- H-2-829157, TWRS Retrieval Level 1 Logic Waste Feed Delivery LAW 7th \& 8th Feed Batches Tank AN-107

- $\quad$ H-2-829158, TWRS Retrieval Level 1 Logic Waste Feed Delivery LAW 9th Feed Batches Tank $A N-102$

- H-2-829159, TWRS Retrieval Level 1 Logic Waste Feed Delivery LAW 10th Feed Batches Tank AN-106

- H-2-829160, TWRS Retrieval Level 1 Logic Waste Feed Delivery LAW 11th Feed Batches Tank SY-101

- $\quad$ H-2-829161, TWRS Retrieval Level 1 Logic Waste Feed Delivery LAW 12th Feed Batches Tank $S Y-103$

- $\quad$ H-2-829162, TWRS Retrieval Level 1 Logic Waste Feed Delivery HLW 1st \& 2nd Feed Batches First Tank, AZ-101

- H-2-829163, TWRS Retrieval Level 1 Logic Waste Feed Delivery HLW 3rd \& 4th Feed Batches Second Tank, AZ-102

- H-2-829164, TWRS Retrieval Level 1 Logic Waste Feed Delivery HLW 5th - 9th Feed Batches Third Tank, AY-102

- H-2-829165, TWRS Retrieval Level 1 Logic Waste Feed Delivery HLW 10th - 12th Feed Batches Fourth Tank, C-104

- H-2-829166, TWRS Level 0 Logic (2 Sheets)

\section{Documents}

ANSI, 1993, Selection, Qualification, and Training of Personnel for Nuclear Power Facilities, ANSI/ANS-3.1-1993, American National Standards Institute, New York, New York.

Acree, C. D., Jr., 1998, Tank Waste Remediation System Mission Analysis Report, HNF-SD-WM-MAR-008, Rev. 2, prepared by Lockheed Martin Hanford Corporation for Fluor Daniel Hanford, Inc., Richland, Washington.

Baldwin, J. H., T. J. McLaughlin, R. D. Potter, and R. L. Treat, 1998, Tank Waste Remediation System Retrieval and Disposal Mission Key Enabling Assumptions, HNF-1945, Rev. 0, prepared by Lockheed Martin Hanford Corporation for Fluor Daniel Hanford, Inc., Richland, Washington.

Borneman, L. E., 1998, Tank Waste Remediation System Environmental Program Plan, HNF-1773, Rev. 0, prepared by Lockheed Martin Hanford Corporation for Fluor Daniel Hanford, Inc., Richland, Washington. 
Brown, N. R., 1996, LLW Product Waste Loading Assumptions for the TWRS Process Flowsheet, (internal memorandum to R. M. Orme, April 23), U.S. Department of Energy, Richland, Washington.

Conway, J. T., 1997, (letter to Federico F. Peña, Secretary, U.S. Department of Energy, November 12), Defense Nuclear Facilities Safety Board, Washington, D.C.

DOE and Ecology, 1996, Tank Waste Remediation System, Hanford Site, Richland, Washington, Final Environmental Impact Statement, DOE/EIS-0189, U.S. Department of Energy and Washington State Department of Ecology, Washington, D.C.

Ecology, EPA, and DOE, 1996, Hanford Federal Facility Agreement and Consent Order, 2 vols., Washington State Department of Ecology, U.S. Environmental Protection Agency, and U.S. Department of Energy, Olympia, Washington.

FDH, 1997, Tank Waste Remediation System Basis for Interim Operation, HNF-SD-WM-BIO-001, Rev. 0, Fluor Daniel Hanford, Inc., Richland, Washington.

Freeman, D. V., 1998, Tank Waste Remediation System Program Plan, HNF-1883, Rev. 0, prepared by Lockheed Martin Hanford Corporation for Fluor Daniel Hanford, Inc., Richland, Washington.

Goetz, T. G., D. M. Hammond, and J. P. Harris III, 1998, Tank Waste Remediation System Retrieval and Disposal Mission Authorization Basis Amendment Task Plan, HNF-1722, Rev. 0, prepared by Lockheed Martin Hanford Corporation for Fluor Daniel Hanford, Inc., Richland, Washington.

Hall, C. A., 1998, Tank Waste Remediation System Retrieval and Disposal Mission Readiness-toProceed Guidance and Requirements to Deliverables Crosswalk, HNF-2020, Rev. 0, prepared by Lockheed Martin Hanford Corporation for Fluor Daniel Hanford, Inc., Richland, Washington.

Hanlon, B.M., 1997, Waste Tank Summary Report for Month Ending July 31, 1997, HNF-EP0182-112, prepared by Lockheed Martin Hanford Corporation for Fluor Daniel Hanford, Inc., Richland, Washington.

LMHC, 1997, TWRS Administration, HNF-IP-0842, Fluor Daniel Hanford, Inc., Richland, Washington.

Mickle, G. D., 1995, Tank Farm Health and Safety Plan, WHC-SD-WM-HSP-002, Rev. 2, Westinghouse Hanford Company, Richland, Washington. 
Payne, M. A., P. J. Certa, J. O. Honeyman, J. G. Kristofzski, and W. T. Thompson, 1998, Management Assessment of Tank Waste Remediation System Contractor Readiness to Proceed With Phase $1 B$ Privatization, HNF-2021, Rev. 0, prepared by Lockheed Martin Hanford Corporation for Fluor Daniel Hanford, Inc., Richland, Washington.

Peck, L.G., 1998, Tank Waste Remediation System Systems Engineering Management Plan, HNF-SD-WM-SEMP-002, Rev. 1, prepared by Lockheed Martin Hanford Corporation for Fluor Daniel Hanford, Inc., Richland, Washington.

Popielarczyk, R. S., 1996, TWRS Safety Management Plan, WHC-SD-WM-PLN-114, Rev. 1, Westinghouse Hanford Company, Richland, Washington.

Rifaey, S. H., 1998, Tank Waste Remediation System Engineering Plan, HNF-1947, Rev. 0, prepared by Lockheed Martin Hanford Corporation for Fluor Daniel Hanford, Inc., Richland, Washington.

RL, 1996a, British Nuclear Fuels Laboratory Private Contract, DE-AC06-96RL13308, U.S. Department of Energy, Richland Operations Office, Richland, Washington.

RL, 1996b, Lockheed Martin Advanced Environmental Systems Private Contract, DE-AC06-96RL13309, U.S. Department of Energy, Richland Operations Office, Richland, Washington.

RL, 1996c, Hanford Strategic Plan, DOE/RL 96-92, Rev. 0, U.S. Department of Energy, Richland Operations Office, Richland, Washington.

RL, 1996d, Project Hanford Management Contract, DE-AC06-96RL13200, U.S. Department of Energy, Richland Operations Office, Richland, Washington.

Schaus, P. S., 1997, 1997, Tank Waste Remediation System Retrieval and Disposal Mission Readiness-to-Proceed Internal Independent Assessment, HNF-2018, Rev. 0, prepared by Lockheed Martin Hanford Corporation for Fluor Daniel Hanford, Inc., Richland, Washington.

Schein, G., 1997, Draft Reports Confirm Hanford Tank Farm Leaks Contributing Source of Groundwater Contamination, DOE News, November 25, 1997, U.S. Department of Energy, Richland, Operations Office, Richland, Washington.

Strode, J. N., and V. C. Boyles, 1997, Operational Waste Volume Projection, HNF-SD-WM-ER-029, Rev. 23, prepared by Lockheed Martin Hanford Corporation for Fluor Daniel Hanford, Inc., Richland, Washington. 
HNF-2019 Rev 0

Swita, W. R., M. R. Lewis, and M. J. O'Neill, 1998, Tank Waste Remediation System Retrieval and Disposal Mission Initial Updated Baseline Summary, HNF-1946, Rev. 0, prepared by Lockheed Martin Hanford Corporation for Fluor Daniel Hanford, Inc., Richland, Washington.

Taylor, W.J., 1997, Contract Number DE-ACO6-96RL13200, Tank Waste Remediation System (TWRS) Privatization - Hanford Contractors Readiness-to-Proceed, (letter 97-WDD-129 to H. J. Hatch, Fluor Daniel Hanford, Inc., August 8), U.S. Department of Energy, Richland Operations Office, Richland, Washington.

Treat, R., P. Bartley, T. J. McLaughlin, R. D. Potter, R. E. Raymond, and W. L. Willis, 1998, Tank Waste Remediation System Retrieval and Disposal Mission Technical Baseline Summary Description, HNF-1901, Rev. 0, prepared by Lockheed Martin Hanford Corporation for Fluor Daniel Hanford, Inc., Richland, Washington.

Vann, J. M., E. R. Hamm, and R. D. Crisp, 1998, Tank Waste Remediation System Configuration Management Plan, HNF-1900, Rev. 0, prepared by Lockheed Martin Hanford Corporation for Fluor Daniel Hanford, Inc., Richland, Washington.

Wells, M. W., 1998, Tank Waste Remediation System Retrieval and Disposal Mission Phase 1 Financial Analysis, HNF-2017, Rev. 0, prepared by-Lockheed Martin Hanford Corporation for Fluor Daniel Hanford, Inc., Richland, Washington.

Wilson, M., 1997, (letter to J. D. Wagoner, Manager, U.S. Department of Energy, Richland Operations Office, November 19), Washington State Department of Ecology, Olympia, Washington.

- Wojtasek, R. D., 1997, Readiness-To-Proceed Plan for M\&I Contractor Workscope in Support of TWRS Phase $1 B$ Privatization, HNF-SP-1241, Rev.0, prepared by Lockheed Martin Hanford Corporation for Fluor Daniel Hanford, Inc., Richland, Washington.

Zimmerman, B. D., 1998a, Tank Waste Remediation System Risk Management Plan, HNF-SD-WM-PMP-018, Rev. 2, prepared by Lockheed Martin Hanford Corporation for Fluor Daniel Hanford, Inc., Richland, Washington.

Zimmerman, B. D., 1998b, Tank Waste Remediation System Retrieval and Disposal Mission Risk List, Rev. 0, prepared by Lockheed Martin Hanford Corporation for Fluor Daniel Hanford, Inc., Richland, Washington. 
HNF-2019 Rev 0

APPENDIX A

CHECKLIST FROM AUGUST 8, 1997

LETTER FROM RL TO FDH 


\section{LIST OF TERMS}

DOE

DQO

FY

ICD

LCAM

LMHC

MAR

MYWP

O\&M

PHMC

RAM

SSC

S/RIDS

TBR

TMXS

TWRS

WBS
U.S. Department of Energy

data quality objective

fiscal year

interface control document

Life Cycle Asset Management

Lockheed Martin Hanford Corporation

Mission Analysis Report

multi-year work plan

Operations and Maintenance

Project Hanford Management Contract

reliability, availability, and maintainability (analysis)

system, structure, and component

standards/requirements identification document

Technical Basis Review

Training Matrix System

Tank Waste Remediation System

work breakdown structure 
HNF-2019 Rev 0

\section{CHECKLIST FOR MANAGEMENT AND INTEGRATION CONTRACTOR READINESS-TO-PROCEED}

\begin{tabular}{|c|c|c|c|}
\hline & Item & Response & Status \\
\hline \multicolumn{4}{|c|}{ Technical Baseline } \\
\hline & $\begin{array}{l}\text { Tank Waste Remediation } \\
\text { System (TWRS) Project } \\
\text { Analysis is complete and } \\
\text { consistent with higher-level } \\
\text { plans and specifications. }\end{array}$ & $\begin{array}{l}\text { HNF-SD-WM-MAR-008, Tank Waste Remediation } \\
\text { System Mission Analysis Report (MAR), }{ }^{\mathrm{a}} \text { was } \\
\text { updated to reflect higher level plans and } \\
\text { specifications, including DOE/RL 96-92, Hanford } \\
\text { Strategic Plan }{ }^{b} \text { and DE-AC06-96RL13200, Project } \\
\text { Hanford Management Contract (PHMC). }{ }^{\circ} \text { An } \\
\text { evaluation of the completeness of requirements } \\
\text { considered in developing the MAR }{ }^{\mathrm{a}} \text { is included in } \\
76000-97-\mathrm{LGP}-001, \text { Verification of Document } \\
\text { Requirements in TWRS Mission Analysis Report and } \\
\text { Facility Specifications. }^{\mathrm{d}}\end{array}$ & Green \\
\hline & $\begin{array}{l}\text { Requirements are identified, } \\
\text { validated, and documented. }\end{array}$ & $\begin{array}{l}\text { Higher level plans and specifications are identified } \\
\text { and documented in the MAR. }{ }^{a} \text { HNF-1901, Tank } \\
\text { Waste Remediation System Retrieval and Disposal } \\
\text { Mission Technical Baseline Summary Description, } \\
\text { was prepared to identify the documents that address } \\
\text { the performance requirements; operational concepts; } \\
\text { functions to be performed; systems, structures, and } \\
\text { components (SSCs) required. It cites the RDD-100 } \\
\text { database }{ }^{f} \text { and standards/requirements identification } \\
\text { documents (S/RIDs) as approved sources of } \\
\text { requirements. }\end{array}$ & Green \\
\hline & $\begin{array}{l}\text { Requirements are allocated to } \\
\text { functions. } \\
\text { (Note: The functions in this } \\
\text { context are equivalent to the } \\
\text { functional organizations) }\end{array}$ & $\begin{array}{l}\text { The baseline enhancement process, documented in } \\
\text { HNF-1946, Tank Waste Remediation System } \\
\text { Retrieval and Disposal Mission Initial Updated } \\
\text { Baseline Summary, }{ }^{g} \text { identified known requirements } \\
\text { and allocated them to the TWRS Project functional } \\
\text { organizations. HNF-1946 }{ }^{\mathrm{g}} \text { and supporting } \\
\text { Technical Basis Reviews (TBRs) allocated } \\
\text { requirements to each activity and the functional } \\
\text { organization responsible for the activity. Additional } \\
\text { requirements will be allocated to functional } \\
\text { organizations to support annual multi-year work } \\
\text { plan (MYWP) efforts. }\end{array}$ & Green \\
\hline
\end{tabular}


HNF-2019 Rev 0

\section{CHECKLIST FOR MANAGEMENT AND INTEGRATION CONTRACTOR READINESS-TO-PROCEED}

\begin{tabular}{|c|c|c|c|}
\hline \multicolumn{2}{|r|}{ Item } & \multirow[b]{2}{*}{$\begin{array}{l}\text { Response } \\
\text { The need for each activity was verified during the } \\
\text { baseline enhancement process. Enhancements were } \\
\text { reconciled to HNF-SP-1230, Tank Waste } \\
\text { Remediation System Fiscal Year } 1998 \text { Multi-Year } \\
\text { Work Plan WBS I.I (TWRS MYWP). }{ }^{\mathrm{h}} \text { The } \\
\text { enhanced baseline is summarized in HNF-1946, }{ }^{\mathrm{g}} \\
\text { which includes the Level } 1 \text { Logics, }{ }^{\mathrm{i}} \text { Schedule } \\
\text { Baseline, Cost Baseline and HNF-2017, Tank Waste } \\
\text { Remediation System Retrieval and Disposal Mission } \\
\text { Phase } 1 \text { Financial Analysis. All activities shown in } \\
\text { the enhanced baseline directly support mission } \\
\text { objectives defined in the MAR. }\end{array}$} & \multirow{2}{*}{$\frac{\text { Status }}{\text { Green }}$} \\
\hline 4. & $\begin{array}{l}\text { Each activity is tied to and } \\
\text { necessary to support a } \\
\text { contractual requirement. }\end{array}$ & & \\
\hline 5. & $\begin{array}{l}\text { Architecture is defined based } \\
\text { on analyses of the mission and } \\
\text { the functions and requirements. }\end{array}$ & $\begin{array}{l}\text { The mission is defined in the MAR. }{ }^{a} \text { It is traceable } \\
\text { to the Hanford Site Technical Baseline, as described } \\
\text { in HNF-1901, and the enhanced baseline (Level } 1 \\
\text { Logics'). The MAR }{ }^{\text {a }} \text { has functional requirements } \\
\text { allocated to the architecture. The planned system } \\
\text { specifications (one for each major facility) will } \\
\text { continue the process of decomposition of functional } \\
\text { flow block diagrams, requirements analysis, and } \\
\text { synthesis. This process is defined in } \\
\text { HNF-SD-WM-SEMP-002, Tank Waste Remediation } \\
\text { System Systems Engineering Management Plan. }\end{array}$ & Green \\
\hline 6. & $\begin{array}{l}\text { Enabling assumptions have } \\
\text { been formally documented. } \\
\text { Assumptions which have been } \\
\text { replaced with facts or decisions } \\
\text { have been changed in } \\
\text { requirements documentation. }\end{array}$ & $\begin{array}{l}\text { Key assumptions were documented in HNF-1945, } \\
\text { Tank Waste Remediation System Retrieval and } \\
\text { Disposal Mission Key Enabling Assumptions. }{ }^{1} \text { This } \\
\text { list also contains the validation status of each key } \\
\text { enabling assumption. }\end{array}$ & Green \\
\hline 7. & $\begin{array}{l}\text { Technical logics are complete; } \\
\text { the program makes sense } \\
\text { logically; and lower-level logic } \\
\text { rolls up properly to higher- } \\
\text { level logic. }\end{array}$ & $\begin{array}{l}\text { HNF-1946 includes the technical logics at Level } 7 \\
\text { of the WBS and the TBR data packages (on file) } \\
\text { contain logic details at Level } 8 \text { of the WBS. These } \\
\text { logic diagrams roll up to the TWRS Level 0 Logics. }\end{array}$ & Green \\
\hline
\end{tabular}


HNF-2019 Rev 0

\section{CHECKLIST FOR MANAGEMENT AND INTEGRATION CONTRACTOR READINESS-TO-PROCEED}

\begin{tabular}{|c|c|c|c|}
\hline & Item & Response & Status \\
\hline 8. & $\begin{array}{l}\text { Operations plans that describe } \\
\text { how the Project Hanford } \\
\text { Management Contract (PHMC) } \\
\text { team will execute the Technical } \\
\text { Baseline have been prepared } \\
\text { for all projects and are } \\
\text { supported by lower-tier plans. } \\
\text { The operations plans are } \\
\text { consistent with the MYWP } \\
\text { and Life Cycle Asset } \\
\text { Management (LCAM). } \\
\text { Operations and Maintenance } \\
\text { (O\&M) plans are integrated. } \\
\text { (Note: The operations plans in } \\
\text { this context are equivalent to } \\
\text { the program plans; "projects" } \\
\text { includes both project and } \\
\text { functional organizations) }\end{array}$ & $\begin{array}{l}\text { Lower-tier program plans were developed and are } \\
\text { documented in HNF-1883, Tank Waste Remediation } \\
\text { System Program Plan, }{ }^{\mathrm{m}} \text { and in the subproject plans: } \\
\text { HNF-1881, Tank Waste Remediation System } \\
\text { Retrieval and Disposal Mission Waste Feed } \\
\text { Delivery Plan; }{ }^{\mathrm{n}} \text { HNF-1882, Tank Waste } \\
\text { Remediation System Retrieval and Disposal Mission } \\
\text { Infrastructure Plan; }{ }^{\circ} \text { HNF-1517, Tank Waste } \\
\text { Remediation System Retrieval and Disposal Mission } \\
\text { Immobilized Low-Activity Waste Disposal Plan; }{ }^{\text {p }} \\
\text { and HNF-1751, Tank Waste Remediation System } \\
\text { Retrieval and Disposal Immobilized High-Level } \\
\text { Waste Storage Plan. }{ }^{9} \text { These plans describe how } \\
\text { projects and functional organizations will execute } \\
\text { the baselines. The project and functional } \\
\text { organization execution plans are consistent with } \\
\text { LCAM guidance and the TWRS MYWP. }{ }^{\circ} \\
\text { Execution plans for Tank Farm Operations and } \\
\text { TWRS Maintenance were incorporated into } \\
\text { HNF-1883, Tank Waste Remediation System } \\
\text { Program Plan. }{ }^{\mathrm{m}} \\
\\
\text { Also see: HNF-1901, Tank Waste Remediation } \\
\text { System Retrieval and Disposal Mission Technical } \\
\text { Baseline Summary Description. }\end{array}$ & Green \\
\hline
\end{tabular}




\section{CHECKLIST FOR MANAGEMENT AND INTEGRATION CONTRACTOR READINESS-TO-PROCEED}

\begin{tabular}{|c|c|c|c|}
\hline & Item & Response & Status \\
\hline & $\begin{array}{l}\text { System boundaries and } \\
\text { interfaces with other } \\
\text { organizations and } \\
\text { programs/projects are defined. }\end{array}$ & 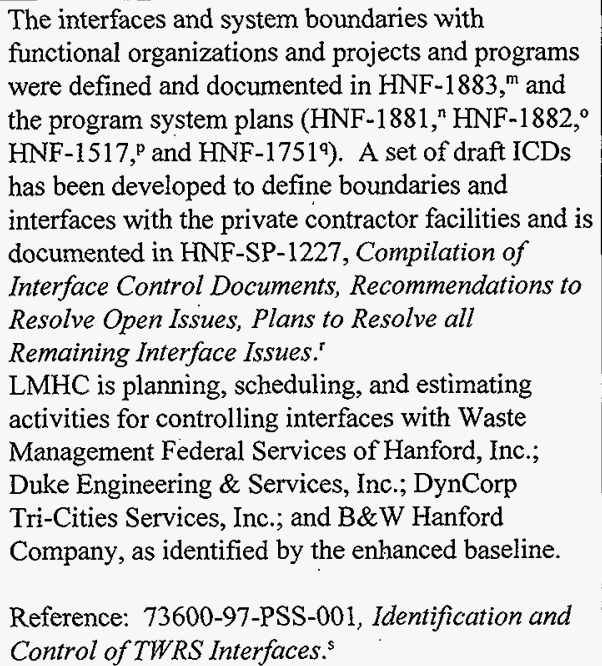 & Green \\
\hline
\end{tabular}


HNF-2019 Rev 0

\section{CHECKLIST FOR MANAGEMENT AND INTEGRATION CONTRACTOR READINESS-TO-PROCEED}

\begin{tabular}{|c|c|c|c|}
\hline \multicolumn{2}{|r|}{ Item } & Response & Status \\
\hline 10. & $\begin{array}{l}\text { ICDs have been prepared, U.S. } \\
\text { Department of Energy (DOE) } \\
\text { comments have been resolved, } \\
\text { issues have been addressed, } \\
\text { and approved interfaces are } \\
\text { managed. }\end{array}$ & 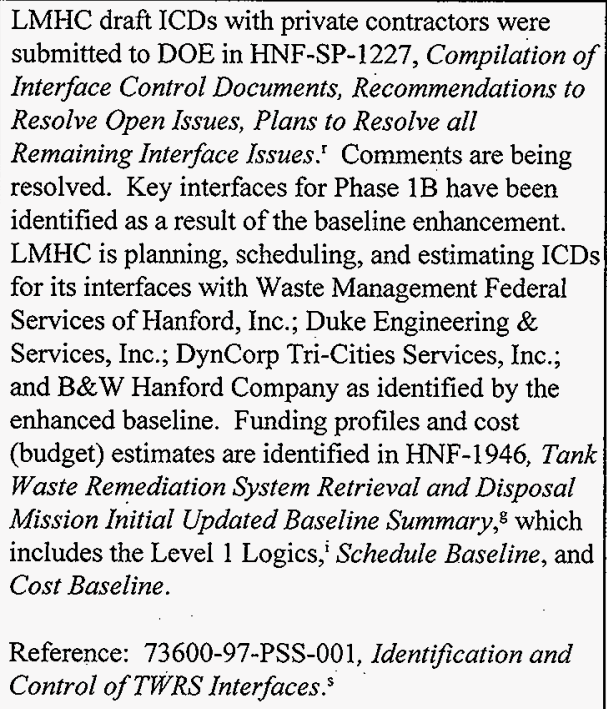 & Green \\
\hline & $\begin{array}{l}\text { Waste feed plans and } \\
\text { implementing actions and } \\
\text { procedures are on track. }\end{array}$ & $\begin{array}{l}\text { The latest revision to HNF-SD-WM-SP-012, Tank } \\
\text { Waste Remediation System Operations and } \\
\text { Utilization Plan, }{ }^{\prime} \text { was submitted to DOE on } \\
\text { schedule in September 1997, and a revision is } \\
\text { planned for completion in September } 1998 . \text { This } \\
\text { document defines waste. feed preparation and } \\
\text { staging plans for Phase 1B. Implementing program } \\
\text { plans are included in HNF-1881, Tank Waste } \\
\text { Remediation System Retrieval and Disposal Mission } \\
\text { Waste Feed Delivery Plan. }{ }^{n} \text { Implementing actions } \\
\text { and procedures are identified, and their completion } \\
\text { dates are scheduled in the baseline enhancement } \\
\text { (Level } 1 \text { Logics). }{ }^{1} \text { The baseline enhancement is } \\
\text { included in HNF-1946, Tank Waste Remediation } \\
\text { System Retrieval and Disposal Mission Initial } \\
\text { Updated Baseline Summary. }\end{array}$ & Green \\
\hline
\end{tabular}


HNF-2019 Rev 0

\section{CHECKLIST FOR MANAGEMENT AND INTEGRATION CONTRACTOR READINESS-TO-PROCEED}

\begin{tabular}{|c|c|c|c|}
\hline \multicolumn{2}{|r|}{ Item } & \multirow[b]{2}{*}{$\begin{array}{l}\text { Response } \\
\text { The baseline enhancement includes the } \\
\text { infrastructure support activities for Phase 1B, which } \\
\text { have been combined under a single project (W-519). } \\
\text { Infrastructure support activities are described in } \\
\text { HNF-1882, Tank Waste Rernediation System } \\
\text { Retrieval and Disposal Mission Infrastructure } \\
\text { Plan, }{ }^{\circ} \text { and HNF-1883, Tank Waste Remediation } \\
\text { System Program Plan, }{ }^{\mathrm{m}} \text { and procedures are } \\
\text { identified, and their completion dates are scheduled } \\
\text { in HNF-1946, Tank Waste Remediation System } \\
\text { Retrieval and Disposal Mission Initial Updated } \\
\text { Baseline Summary. }\end{array}$} & \multirow{2}{*}{$\frac{\text { Status }}{\text { Green }}$} \\
\hline 12. & $\begin{array}{l}\text { Infrastructure support plans and } \\
\text { implementing actions and } \\
\text { procedures are on track. }\end{array}$ & & \\
\hline 13. & $\begin{array}{l}\text { Immobilized waste product } \\
\text { project plans and implementing } \\
\text { actions and procedures are on } \\
\text { track. }\end{array}$ & $\begin{array}{l}\text { The baseline enhancement includes immobilized } \\
\text { waste product storage and disposal activities to } \\
\text { support Phase 1B. These activities are described in } \\
\text { HNF-1517, Tank Waste Remediation System } \\
\text { Retrieval and Disposal Mission Immobilized } \\
\text { Low-Activity Waste Disposal Plan, }{ }^{\mathrm{p}} \text { and HNF-1751, } \\
\text { Tank Waste Remediation System Retrieval and } \\
\text { Disposal Mission Immobilized High-Level Waste } \\
\text { Storage Plan. }{ }^{\mathrm{q}} \text { Implementing actions and } \\
\text { procedures are identified and their completion dates } \\
\text { are scheduled in HNF-1946, Tank Waste } \\
\text { Remediation System Retrieval and Disposal Mission } \\
\text { Initial Updated Baseline Summary. }\end{array}$ & Green \\
\hline 14. & $\begin{array}{l}\text { Plans and implementing } \\
\text { actions that support private } \\
\text { contract requirements for } \\
\text { dealing with waste processing } \\
\text { facility byproducts including } \\
\text { interfacing with other } \\
\text { contractors are on track. }\end{array}$ & $\begin{array}{l}\text { Draft ICDs among the private contractors, RL, and } \\
\text { the M\&I contractor that deal with private contractor } \\
\text { byproducts were prepared and submitted to RL in } \\
\text { July } 1997 . \\
\text { References: HNF-SP-1227, Compilation of } \\
\text { Interface Control Documents, Recommendations to } \\
\text { Resolve Open Issues, Plans to Resolve Remaining } \\
\text { Interface Issues. }\end{array}$ & Green \\
\hline
\end{tabular}


HNF-2019 Rev 0 .

\section{CHECKLIST FOR MANAGEMENT AND INTEGRATION CONTRACTOR READINESS-TO-PROCEED}

\begin{tabular}{|c|c|c|c|}
\hline \multicolumn{2}{|r|}{ Item } & Response & Status \\
\hline 15. & $\begin{array}{l}\text { Technical risks have been } \\
\text { identified and are being } \\
\text { managed. }\end{array}$ & 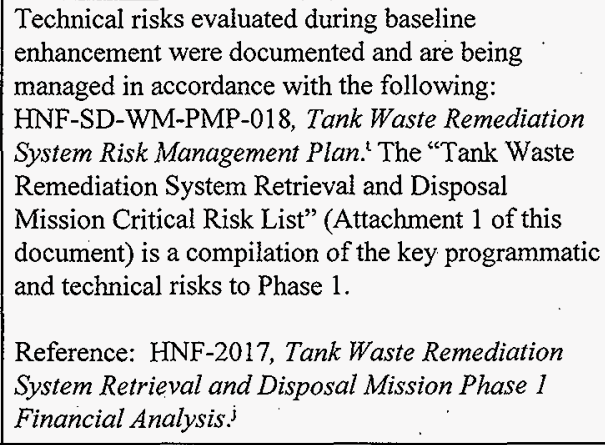 & Green \\
\hline 16. & $\begin{array}{l}\text { The Technical Baseline is } \\
\text { complete and defensible and } \\
\text { represents best value to the } \\
\text { government. } \\
\text { (Note: The Technical Baseline } \\
\text { in this context is equivalent to } \\
\text { the scope baseline) }\end{array}$ & $\begin{array}{l}\text { The Technical Baseline is considered complete and } \\
\text { defensible (1) as a result of the baseline } \\
\text { enhancement process and (2) upon acceptance by } \\
\text { RL. Specification development and optimization } \\
\text { analyses will continue over the next three to four } \\
\text { years to ensure that the physical systems to be } \\
\text { installed and operated represent best value to the } \\
\text { government. Key uncertainties in the technical } \\
\text { baseline are captured in the "Tank Waste } \\
\text { Remediation System Retrieval and Disposal } \\
\text { Mission Critical Risk List," (Attachment 1) and } \\
\text { HNF-1945, Tank Waste Remediation System } \\
\text { Retrieval and Disposal Mission Key Enabling } \\
\text { Assumptions.' }\end{array}$ & Green \\
\hline 17. & $\begin{array}{l}\text { The Technical Baseline is } \\
\text { under configuration control. }\end{array}$ & $\begin{array}{l}\text { HNF-1900, Tank Waste Remediation System } \\
\text { Configuration Management Plan, }{ }^{\vee} \text { and HNF-1883, } \\
\text { Tank Waste Remediation System Program Plan, }{ }^{\mathrm{m}} \\
\text { defines the types of documents that will be placed } \\
\text { under configuration control. HNF-1901, Tank } \\
\text { Waste Remediation System Retrieval and Disposal } \\
\text { Mission Technical Baseline Summary Description, } \\
\text { was prepared to identify documents that the } \\
\text { Technical Baseline, including those that are under } \\
\text { configuration control. The programmatic baseline } \\
\text { (HNF-1946 }{ }^{\circ} \text { ) is also under configuration control. }\end{array}$ & Green \\
\hline
\end{tabular}


HNF-2019 Rev 0

\section{CHECKLIST FOR MANAGEMENT AND INTEGRATION CONTRACTOR READINESS-TO-PROCEED}

\begin{tabular}{|c|c|c|c|}
\hline \multicolumn{2}{|r|}{ Item } & Response & Status \\
\hline 18. & $\begin{array}{l}\text { System reliability, availability, } \\
\text { and maintainability have been } \\
\text { assessed and are sufficient to } \\
\text { support processing rate } \\
\text { requirements. }\end{array}$ & $\begin{array}{l}\text { A reliability, availability, and maintainability } \\
\text { (RAM) analysis is in progress and will be completed } \\
\text { for the first waste feed batches during fiscal year } \\
\text { (FY) 1998. Further analyses will be done in future } \\
\text { years as systems are further defined. The Level } 1 \\
\text { Logicsi baseline enhancement documents the } \\
\text { (620.020) activity. } \\
\text { Furthermore, the planning basis for retrieval is } \\
\text { primarily the historical experience of tank waste } \\
\text { transfers, additions, and equipment operations. } \\
\text { While a formal RAM analysis has not yet been } \\
\text { completed, actual tank farm system RAM is } \\
\text { available through the use of these historical data. } \\
\\
\text { Reference: HNF-1946, Tank Waste Remediation } \\
\text { System Retrieval and Disposal Mission Initial } \\
\text { Updated Baseline Summary.g }\end{array}$ & Green \\
\hline 19. & $\begin{array}{l}\text { The physical integrity of } \\
\text { existing systems, structures, } \\
\text { and components has been } \\
\text { verified. }\end{array}$ & $\begin{array}{l}\text { Design reconstitution of existing systems, } \\
\text { structures, and components, is an ongoing activity. } \\
\text { Pipeline integrity assessments are planned. The } \\
\text { baseline enhancement (Level } 1 \text { Logics) }{ }^{\mathrm{I}} \text { identified } \\
\text { when the assessments are required to support } \\
\text { Phase 1B (example: Activity \# 620.020). } \\
\text { Reference: HNF-1946, Tank Waste Remediation } \\
\text { System Retrieval and Disposal Mission Initial } \\
\text { Updated Baseline Summary.s }\end{array}$ & Green \\
\hline
\end{tabular}


HNF-2019 Rev 0

\section{CHECKLIST FOR MANAGEMENT AND INTEGRATION CONTRACTOR READINESS-TO-PROCEED}

\begin{tabular}{|c|c|c|c|}
\hline \multicolumn{2}{|r|}{ Item } & Response & Status \\
\hline 20. & $\begin{array}{l}\text { Waste has been characterized } \\
\text { as necessary to satisfy all Data } \\
\text { Quality Objectives (DQOs). }\end{array}$ & 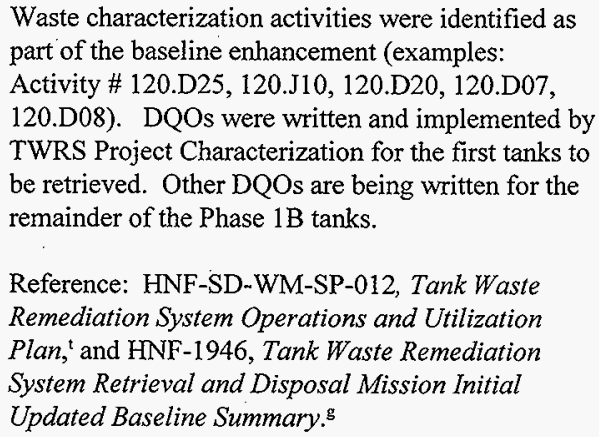 & Green \\
\hline 21. & $\begin{array}{l}\text { The ability of the PHMC team } \\
\text { to support alternatives other } \\
\text { than the baseline has been } \\
\text { evaluated from a technical } \\
\text { perspective. }\end{array}$ & $\begin{array}{l}\text { The TWRS Contractor has ensured that } \\
\text { management and engineering systems are in place to } \\
\text { support alternatives other than the enhanced } \\
\text { baseline. } \\
\text { A series of "what if" analyses of alternatives defined } \\
\text { by RL will be conducted following submittal of } \\
\text { Phase } 1 \text { documents and plans by the PCS. This } \\
\text { work has been budgeted in the FY } 1998 \text { MYWP, } \\
\text { and will use such tools as the HTWOS model. } \\
\text { Reference: HNF-1883, Tank Waste Remediation } \\
\text { System Program Plan;" HNF-SD-WM-PMP-018, } \\
\text { Tank Waste Remediation System Risk Management } \\
\text { Plan;"Tank Waste Remediation System Retrieval } \\
\text { and Disposal Mission Critical Risk List" } \\
\text { (Attachment 1); and HNF-SD-WM-SEMP-002, } \\
\text { Tank Waste Remediation System Systems } \\
\text { Engineering Management Plan." }\end{array}$ & Green \\
\hline
\end{tabular}




\section{CHECKLIST FOR MANAGEMENT AND INTEGRATION CONTRACTOR READINESS-TO-PROCEED}

\begin{tabular}{|c|c|c|c|}
\hline \multicolumn{2}{|r|}{ Item } & Response & Status \\
\hline \multicolumn{4}{|c|}{ Programmatic Baseline } \\
\hline 22. & $\begin{array}{l}\text { Resource-loaded estimates and } \\
\text { schedules have been completed } \\
\text { for all activities. }\end{array}$ & $\begin{array}{l}\text { Baseline enhancement activities included the } \\
\text { development of estimated cost and schedule } \\
\text { information which is contained in HNF } 1946 \text {, Tank } \\
\text { Waste Remediation System Retrieval and Disposal } \\
\text { Mission Initial Updated Baseline Summary.g }\end{array}$ & Green \\
\hline 23. & $\begin{array}{l}\text { The critical path is identified, } \\
\text { and float has been calculated. }\end{array}$ & $\begin{array}{l}\text { The preliminary critical path was identified and } \\
\text { float was calculated during the baseline } \\
\text { enhancement process. } \\
\text { Reference: HNF-1946, Tank Waste Remediation } \\
\text { System Retrieval and Disposal Mission Initial } \\
\text { Updated Baseline Summary, which includes the } \\
\text { Level } 1 \text { Logics', Schedule Baseline, and Cost } \\
\text { Baseline. }\end{array}$ & Green \\
\hline 24. & $\begin{array}{l}\text { Activities have been properly } \\
\text { funded. }\end{array}$ & $\begin{array}{l}\text { The baseline enhancement process included } \\
\text { estimating the cost of each activity at Level } 8 \text { of the } \\
\text { WBS and identifying associated risks. The risks, } \\
\text { estimates, and target funding levels were evaluated } \\
\text { to determine funding issues. The results are } \\
\text { documented in HNF-2017, Tank Waste Remediation } \\
\text { System Retrieval and Disposal Mission Phase } l \\
\text { Financial Analysis. } \\
\text { The cost of planned activities is within } 10 \% \text { of the } \\
\text { current funding baseline. }\end{array}$ & Amber \\
\hline 25. & $\begin{array}{l}\text { Analysis of budget against } \\
\text { resource requirements has been } \\
\text { completed. }\end{array}$ & $\begin{array}{l}\text { A financial analysis of the budget against estimated } \\
\text { resource requirements was completed and is } \\
\text { documented in HNF-2017, Tank Waste Remediation } \\
\text { System Retrieval and Disposal Mission Phase l } \\
\text { Financial Analysis. }\end{array}$ & Green \\
\hline
\end{tabular}




\section{CHECKLIST FOR MANAGEMENT AND INTEGRATION CONTRACTOR READINESS-TO-PROCEED}

\begin{tabular}{|c|c|c|c|}
\hline \multicolumn{2}{|r|}{ Item } & Response & Status \\
\hline 26. & $\begin{array}{l}\text { There is agreement among } \\
\text { scope, budget, and schedule. } \\
\text { The scope of work can be } \\
\text { performed within budget and } \\
\text { on schedule. }\end{array}$ & $\begin{array}{l}\text { Agreement among scope, estimated cost, and } \\
\text { schedule is documented in HNF-1946, Tank Waste } \\
\text { Remediation System Retrieval and Disposal Mission } \\
\text { Initial Updated Baseline Summary, }{ }^{\mathrm{g}} \text { which includes } \\
\text { the Level } 1 \text { Logics, Schedule Baseline, and Cost } \\
\text { Baseline. Budget issues have been identified and } \\
\text { are documented in HNF-2017, Tank Waste } \\
\text { Remediation System Retrieval and Disposal Mission } \\
\text { Phase I Financial Analysis. }\end{array}$ & Amber \\
\hline 27. & $\begin{array}{l}\text { Schedule risk has been } \\
\text { identified and is being } \\
\text { managed. }\end{array}$ & 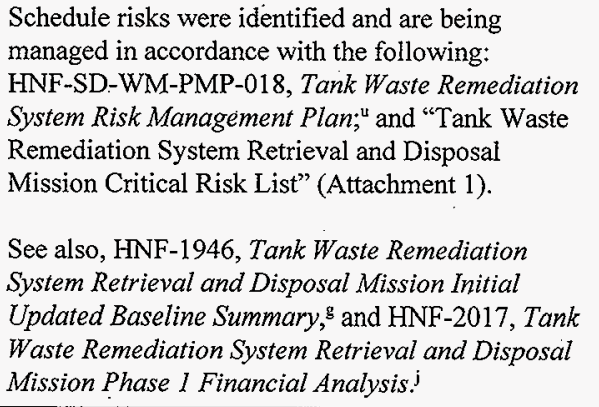 & Green \\
\hline 28. & $\begin{array}{l}\text { The Programmatic Baseline is } \\
\text { under configuration } \\
\text { management, and a change } \\
\text { control system is implemented. }\end{array}$ & $\begin{array}{l}\text { The Programmatic Baseline definition, HNF-1946, } \\
\text { Tank Waste Remediation System Retrieval and } \\
\text { Disposal Mission Initial Updated Baseline } \\
\text { Summary, }{ }^{\mathrm{g}} \text { was completed as part of the baseline } \\
\text { enhancement and will be maintained under } \\
\text { configuration control, as described in HNF-1900, } \\
\text { Tank Waste Remediation System Configuration } \\
\text { Management Plan, }{ }^{,} \text {and HNF-MD-008, Baseline } \\
\text { Change Control Procedure." } \\
\text { See also, HNF-1881, Tank Waste Remediation } \\
\text { System Program Plan. }{ }^{\mathrm{n}}\end{array}$ & Green \\
\hline
\end{tabular}


HNF-2019 Rev 0

\section{CHECKLIST FOR MANAGEMENT AND INTEGRATION CONTRACTOR READINESS-TO-PROCEED}

\begin{tabular}{|c|c|c|c|}
\hline & Item & Response & Status \\
\hline & $\begin{array}{l}\text { The ability to support } \\
\text { alternatives other than the } \\
\text { baseline has been evaluated } \\
\text { from a programmatic } \\
\text { perspective. }\end{array}$ & $\begin{array}{l}\text { Management systems are in place to assess the } \\
\text { scope, schedule and cost of new alternatives, as } \\
\text { described in HNF-1883, Tank Waste Remediation } \\
\text { System Program Plan. } \text { " Alternative assessments are } \text { budgeted in the FY } 1998 \text { MYWP, HNF-SP-1230." } \\
\text { Other associated programmatic documentation is: } \\
\text { HNF-SD-WM-PMP-018, Tank Waste Remediation } \\
\text { System Risk Management Plan, "Tank Waste } \\
\text { Remediation System Retrieval and Disposal } \\
\text { Mission Risk List" (Attachment } 1 \text { ); and } \\
\text { HNF-SD-WM-SEMP-002, Tank Waste Remediation } \\
\text { System Systems Engineering Management Plan. } \\
\text { HNF-SD-WM-MAR-008, Tank Waste Remediation } \\
\text { System Mission Analysis Report, includes strategy } \\
\text { optimization recommendations. It recommends the } \\
\text { evaluation of a number of improvements that, if } \\
\text { adopted, could accelerate the removal of waste from } \\
\text { the SSTs, reduce complexity and scale of the } \\
\text { retrieval mission, and reduce the scale up required to } \\
\text { meet the full-scale production mission requirements. }\end{array}$ & Green \\
\hline
\end{tabular}


HNF-2019 Rev 0

\section{CHECKLIST FOR MANAGEMENT AND INTEGRATION CONTRACTOR READINESS-TO-PROCEED}

\begin{tabular}{|c|c|c|c|}
\hline & Item & Response & Status \\
\hline & & Management Baseline & \\
\hline 30. & $\begin{array}{l}\text { Management systems are in } \\
\text { place to track and report cost, } \\
\text { schedule, and technical } \\
\text { performance and take } \\
\text { appropriate corrective actions. }\end{array}$ & $\begin{array}{l}\text { Business Management for planning, scheduling, } \\
\text { estimating costs, budgeting, work authorization, } \\
\text { contract management, performance measurement, } \\
\text { funds management, contingency management, and } \\
\text { reporting are described in HNF-1883, Tank Waste } \\
\text { Remediation System Program Plan. }{ }^{\mathrm{m}} \text { Costs are } \\
\text { accumulated and tracked through the Financial Data } \\
\text { System. Measured performance against planned and } \\
\text { budgeted workscope is also reported in the Financial } \\
\text { Data System, through the P-3 statused schedules. } \\
\text { Performance reporting occurs on a monthly basis. } \\
\text { Cost and schedule variances outside identified } \\
\text { threshold levels require variance analysis, impact } \\
\text { assessment, and description of corrective actions } \\
\text { required. The Business Management Execution } \\
\text { Plan (HNF-1883, Tank Waste Remediation System } \\
\text { Program Plan, Appendix I) }{ }^{\mathrm{m}} \text { defines the } \\
\text { organizational roles and responsibilities for } \\
\text { planning, financial control, and business operations. } \\
\text { Planning focuses on schedule development, status, } \\
\text { and corrective action. The Financial Control } \\
\text { organization assures estimates are accurately } \\
\text { reflected in the Financial Data System and performs } \\
\text { monthly cost/schedule variance analyses. The } \\
\text { Business Operations organization coordinates the } \\
\text { development of baseline plans. }\end{array}$ & Green \\
\hline
\end{tabular}




\section{CHECKLIST FOR MANAGEMENT AND INTEGRATION CONTRACTOR READINESS-TO-PROCEED}

\begin{tabular}{|c|c|c|c|}
\hline \multicolumn{2}{|r|}{ Item } & Response & Status \\
\hline 31. & $\begin{array}{l}\text { Program planning encompasses } \\
\text { all organizations and facilities, } \\
\text { including support, that } \\
\text { contribute to the mission. }\end{array}$ & $\begin{array}{l}\text { Appendices to HNF-1883, Tank Waste } \\
\text { Remediation System Program Plan, }{ }^{\mathrm{m}} \text { include } \\
\text { execution plans for supporting TWRS Project } \\
\text { organizations, including maintenance; operations; } \\
\text { characterization; engineering; systems engineering } \\
\text { and integration; nuclear safety and licensing; } \\
\text { projects and design; environmental, safety, and } \\
\text { health; business management; and quality assurance. } \\
\text { The Financial Data System used on TWRS Projects } \\
\text { also applies to supporting PHMC team activities. } \\
\text { Appropriate requirements for tracking and reporting } \\
\text { cost and performance are passed on to support } \\
\text { organizations, as described in the work authorization } \\
\text { and contract management sections of HNF-1883, } \\
\text { Tank Waste Remediation System Program Plan. }\end{array}$ & Green \\
\hline 32. & $\begin{array}{l}\text { Environmental permits and } \\
\text { safety authorization bases are } \\
\text { in place as required for the } \\
\text { authorization-to-proceed } \\
\text { decision. }\end{array}$ & $\begin{array}{l}\text { Environmental permit and authorization bases } \\
\text { update activities have been planned and estimated in } \\
\text { HNF-1946, Tank Waste Remediation System } \\
\text { Retrieval and Disposal Mission Initial Updated } \\
\text { Baseline Summary.' HNF-1773, Tank Waste } \\
\text { Remediation System Environmental Program Plan, }{ }^{\times} \\
\text {and HNF-1722, Tank Waste Remediation System } \\
\text { Retrieval and Disposal Mission Authorization Basis } \\
\text { Amendment Task Plan,' also support preparation of } \\
\text { required permits and safety authorization basis } \\
\text { revisions. }\end{array}$ & Green \\
\hline
\end{tabular}




\section{CHECKLIST FOR MANAGEMENT AND INTEGRATION CONTRACTOR READINESS-TO-PROCEED}

\begin{tabular}{|c|c|c|c|}
\hline & Item & Response & Status \\
\hline 33. & $\begin{array}{l}\text { Staff, including managers, are } \\
\text { in place and trained. }\end{array}$ & $\begin{array}{l}\text { Resource planning (including staff and training) is } \\
\text { defined in the baseline enhancement and will be } \\
\text { implemented when the schedule requires it. } \\
\text { Compliance training requirements are defined in } \\
\text { WHC-IP-1184, Training Requirements and } \\
\text { Instructions }{ }^{2} \text { and other related training plans and } \\
\text { procedures. The Training Matrix Subsystem } \\
\text { (TMXS) database }{ }^{\text {aa }} \text { is used to define and track } \\
\text { position qualifications and training requirements. } \\
\text { Specific shortfalls in staffing, e.g., Health Physics } \\
\text { Technicians, and Operations Engineers, have been } \\
\text { identified. } \\
\text { Also see: HNF-1883, Tank Waste Remediation } \\
\text { System Program Plan. }{ }^{\text {m }}\end{array}$ & Amber \\
\hline 34. & $\begin{array}{l}\text { A records management } \\
\text { program, including technical } \\
\text { drawings, has been } \\
\text { implemented. }\end{array}$ & $\begin{array}{l}\text { A document/information management system is } \\
\text { addressed in HNF-1900, Tank Waste Remediation } \\
\text { System Configuration Management Plan, }{ }^{v} \text { and } \\
\text { HNF-1883, Tank Waste Remediation System } \\
\text { Program Plan. }{ }^{\mathrm{m}} \text { The program has been } \\
\text { implemented. }\end{array}$ & Green \\
\hline 35. & $\begin{array}{l}\text { A risk and decision } \\
\text { management program has been } \\
\text { implemented at all levels. }\end{array}$ & $\begin{array}{l}\text { The risk and decision management program was } \\
\text { implemented and is being managed in accordance } \\
\text { with the following: HNF-SD-WM-PMP-018, Tank } \\
\text { Waste Remediation System Risk Management Plan," } \\
\text { and "Tank Waste Remediation System Retrieval and } \\
\text { Disposal Mission Critical Risk List" } \\
\text { (Attachment 1). }\end{array}$ & Green \\
\hline
\end{tabular}


HNF-2019 Rev 0

\section{CHECKLIST FOR MANAGEMENT AND INTEGRATION CONTRACTOR READINESS-TO-PROCEED}

\begin{tabular}{|c|c|c|c|}
\hline \multicolumn{2}{|r|}{ Item } & Response & Status \\
\hline 36. & $\begin{array}{l}\text { The PHMC team has prepared } \\
\text { a readiness-to-proceed (RTP) } \\
\text { memorandum }{ }^{\mathrm{f}} \text { and has } \\
\text { identified deficiencies and } \\
\text { corrective actions, including } \\
\text { funding, necessary to support } \\
\text { privatization. }\end{array}$ & $\begin{array}{l}\text { HNF-2019, Tank Waste Remediation System } \\
\text { Retrieval and Disposal Mission } \\
\text { Readiness-to-Proceed Memorandum, }{ }^{\text {ab }} \text { including } \\
\text { plans for successfully supporting privatization has } \\
\text { been submitted. Uncertainties, deficiencies and } \\
\text { corrective actions are addressed in HNF-1946, Tank } \\
\text { Waste Remediation System Retrieval and Disposal } \\
\text { Mission Initial Updated Baseline Summary,g } \\
\text { HNF-1945, Tank Waste Remediation System } \\
\text { Retrieval and Disposal Mission Key Enabling } \\
\text { Assumptions,' and the "Tank Waste Remediation } \\
\text { System Retrieval and Disposal Mission Critical } \\
\text { Risk List" (Attatchment' 1). Funding issues and } \\
\text { recommendations are included in HNF-2017, Tank } \\
\text { Waste Remediation System Retrieval and Disposal } \\
\text { Mission Phase I Financial Analysis. }\end{array}$ & Green \\
\hline
\end{tabular}

"Acree, C. D., Jr., 1998, Tank Waste Remediation System Mission Analysis Report, HNF-SD-WM-MAR-008, Rev. 2, prepared by Lockheed Martin Hanford Corporation for Fluor Daniel Hanford, Inc., Richland, Washington.

${ }^{b}$ RL, 1996, Hanford Strategic Plan, DOE/RL 96-92, Rev. 0, U.S. Department of Energy, Richland Operations Office, Richland, Washington.

'RL, 1996, Project Hanford Management Contract (PHMC), DE-AC06-96RL13200, U.S. Department of Energy, Richland Operations Office, Richland, Washington.

'Peck, L: G., 1997, Verification of Document Requirements in TWRS Mission Analysis Report and Facility Specifications, (letter 76000-97-LGP-001 to H. L. Boston, Lockheed Martin Hanford Corporation, October 15) Lockheed Martin Hanforo Corporation, Richland, Washington.

'Treat, R., P. Bartley, T. J. McLaughlin, R. D. Potter, R. E. Raymond, and W. L. Willis, 1998, Tank Waste Remediation System Retrieval and Disposal Mission Technical Baseline Summary Description, HNF-1901, Rev. 0, prepared by Lockheed Martin Hanford Corporation for Fluor Daniel Hanford, Inc., Richland, Washington.

'HSTD, n.d., Hanford Site Technical Baseline Database, database maintained by Lockheed Martin Hanford Corporation for Fluor Daniel Hanford, Inc., Richland, Washington.

BSwita, W. R., M. R. Lewis, and M. J. O'Neill, 1998, Tank Waste Remediation System Retrieval and Disposal Mission Initial Updated Baseline Summary, HNF-1946, Rev. 0, prepared by Lockheed Martin Hanford Corporation for Fluor Daniel Hanford, Inc., Richland, Washington.

'Lenseigne, D. L., 1997, Tank Waste Remediation System Fiscal Year 1998 Multi-Year Work Plan WBS 1.1, HNF-SP-1230, Rev. 0, prepared by Lockheed Martin Hanford Corporation for Fluor Daniel Hanford, Inc., Richland, Washington. 
iFDH, 1998, Logic Diagrams, prepared by Lockheed Martin Hanford Corporation for Fluor Daniel Hanford, Inc., Richland, Washington.

- H-2-823148, TWRS Retrieval Level I Logic Immobilized Waste (ILAW)

- H-2-829149, TWRS Retrieval Level I Logic Immobilized Waste (IHLW)

- H-2-829150, TWRS Retrieval Level I Logic Infrastructure Phase I Privatization Support

- H-2-892151, TWRS Retrieval Level I Logic Waste Feed Delivery LAW 1st Feed Batches Tank 241-AN-105

- H-2-829152, TWRS Retrieval Level 1 Logic Waste Feed Delivery LAW 2nd Feed Batches Tank 241-AN-104

- H-2-829153, TWRS Retrieval Level I Logic Waste Feed Delivery LAW 3rd Feed Batches Tank 241-AW-101

- H-2-829154, TWRS Retrieval Level I Logic Waste Feed Delivery LAW 4th Feed Batches Tank 241-AN-103

- H-2-829155, TWRS Retrieval Level I Logic Waste Feed Delivery LAW 5th Feed Batches Tanks 24I-AP-101.\& 241-AW-104

- H-2-829156, TWRS Retrieval Level I Logic Waste Feed Delivery LAW 6th Feed Batches Tank 241-AY-101

- H-2-829157, TWRS Retrieval Level 1 Logic Waste Feed Delivery LAW 7th \& 8th Feed Batches Tank 241-AN-107

- H-2-829158, TWRS Retrieval Level I Logic Waste Feed Delivery LAW 9th Feed Batches Tank 241-AN-102

- H-2-829159, TWRS Retrieval Level I Logic Waste Feed Delivery LAW 10th Feed Batches Tank 241-AN-106

- H-2-829160, TWRS Retrieval Level 1 Logic.Waste Feed Delivery LAW 11th Feed Batches Tank 241-SY-10I

- H-2-829161, TWRS Retrieval Level I Logic Waste Feed Delivery LAW I2th Feed Batches Tank 241-SY-103

- H-2-829162, TWRS Retrieval Level I Logic Waste Feed Delivery HLW Ist \& 2nd Feed Batches First Tank, 24I-AZ-10I

- H-2-829163, TWRS Retrieval Level 1 Logic Waste Feed Delivery HLW 3rd \& 4th Feed Batches Second Tank, 241-AZ-102

- H-2-829164, TWRS Retrieval Level 1 Logic Waste Feed Delivery HLW 5th - 9th Feed Batches Third Tank, 24I-AY-102

- H-2-829165, TWRS Retrieval Level I Logic Waste Feed Delivery HLW 10th-12th Feed Batches Fourth Tank, 24I-C-104

- H-2-829166, TWRS Level 0 Logic (2 Sheets)

jWells, M. W., 1998, Tank Waste Remediation System Retrieval and Disposal Mission Phase 1 Financial Analysis,

HNF-2017, Rev. 0, prepared by Lockheed Martin Hanford Corporation for Fluor Daniel Hanford, Inc., Richland, Washington.

'Peck, L.G., 1998, Tank Waste Remediation System Systems Engineering Management Plan, HNF-SD-WM-SEMP-002,

Rev. 1, prepared by Lockheed Martin Hanford Corporation for Fluor Daniel Hanford, Inc., Richland, Washington.

'Baidwin, J. H., T. J. McLaughlin, R. D. Potter, and R. L. Treat, 1998, Tank Waste Remediation System Retrieval and

Disposal Mission Key Enabling Assumptions, HNF-1945, Rev. 0, prepared by Lockheed Martin Hanford Corporation for Fluor

Daniel Hanford, Inc., Richland, Washington.

${ }^{m}$ Freeman, D. V., 1998, Tank Waste Remediation System Program Plan, HNF-1883, Rev. 0, prepared by Lockheed Martin

Hanford Corporation for Fluor Daniel Hanford, Inc., Richland, Washington.

"Potter, R. D. and R. L. Treat, 1998, Tank Waste Remediation System Retrieval and Disposal Mission Waste Feed

Delivery Plan, HNF-1881, Rev. 0, prepared by Lockheed Martin Hanford Corporation for Fluor Daniel Hanford, Inc., Richland, Washington.

${ }^{\circ}$ Root R. W., Jr., and R. D. Potter, 1998, Tank Waste Remediation System Retrieval and Disposal Mission Infrastructure

Plan, HNF-1882, Rev. 0, prepared by Lockheed Martin Hanford Corporation for Fluor Daniel Hanford, Inc., Richland, Washington.

'Shade, J. W., 1997, Tank Waste Remediation System Retrieval and Disposal Mission Immobilized Low-Activity Waste Disposal Plan, HNF-1517, Rev. 0, prepared by Lockheed Martin Hanford Corporation for Fluor Daniel Hanford, Inc., Richland, Washington.

"Calmus, R. B., 1997, Tank Waste Remediation System Retrieval and Disposal Mission Immobilized High-Level Waste Storage Plan, HNF-1751, Rev, 0, prepared by Lockheed Martin Hanford Corporation for Fluor Daniel Hanford, Inc., Richland, Washington.

'Berry, J. B., 1997, Compilation of Interface Control Documents, Recommendations to Resolve Open Issues, Plans to Resolve All Remaining Interface Issues, HNF-SP-1227, Review Document Not for Public Release, Fluor Daniel Hanford, Inc., Richland, Washington.

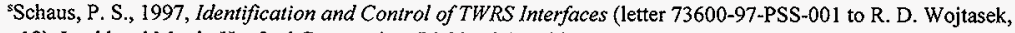
December 19), Lockheed Martin Hanford Corporation, Richland, Washington.

'Kirkbride, R.A., G. K. Allen, P. J. Certa, A. F. Manuel, R. M. Orme, L. W. Shelton, E. J. Slaathaug, R. S. Wittman, and G. T. MacLean, and D. L. Penwell (SESC), 1997, Tank Waste Remediation System Operation and Utilization Plan, HNF-SD-WM-SP-012, Rev. 0, Volumes I and II, prepared by Numatec Hanford Corporation for Fluor Daniel Hanford, Inc., Richland, Washington.

"Zimmerman, B. D., 1998, Tank Waste Remediation System Risk Management Plan, HNF-SD-WM-PMP-018, Rev. 2, prepared by Lockheed Martin Hanford Corporation for Fluor Daniel Hanford, Inc., Richland, Washington. 
'Vann, J. M., E. R. Hamm, and R. D. Crisp, 1998, Tank Waste Remediation System Configuration Management Plan, HNF-1900, Rev. 0, prepared by Lockheed Martin Hanford Corporation for Fluor Daniel Hanford, Inc., Richland, Washington. "FDH, 1997, Baseline Change Control, HNF-MD-008, Rev. 0, Fluor Daniel Hanford, Inc., Richland, Washington.

'Borneman, L. E., 1998, Tank Waste Remediation System Environmental Program Plan, HNF -1773, Rev. 0, prepared by Lockheed Martin Hanford Corporation for Fluor Daniel Hanford, Inc., Richland, Washington.

'Goetz, T. G., D. M. Hammond, and J. P. Harris III, 1998, Tank Waste Remediation System Retrieval and Disposal Mission Authorization Basis Amendment Task Plan, HNF-1722, Rev. 0, prepared by Lockheed Martin Hanford Corporation for Fluor Daniel Hanford, Inc., Richland, Washington.

${ }^{2}$ Duboise, D. M., 1996, Training Requirements and Instructions, WHC-IP-1184, Rev. 0, Westinghouse Hanford Company, Richland, Washington.

a*TMXS, n.d., Training Matrix Subsystem, database maintained by Fluor Daniel Hanford, Inc., Richland, Washington.

ab Boston, H. L., and K. N. Jordan, 1998, Tank Waste Remediation System Retrieval and Disposal Mission Readiness-1oProceed Memorandum, HNF-2019, Rev. 0, prepared by Lockheed Martin Hanford Corporation for Fluor Daniel Hanford, Inc., Richland, Washington. 
HNF-2019 Rev 0

APPENDIX B

GUIDANCE AND REQUIREMENTS TO

DELIVERABLES CROSSWALK

TWRS Retrieval and Disposal Mission

Readiness-to-Proceed Memorandum

$B-i$ 
HNF-2019 Rev 0

This page intentionally left blank.

B-ii 
Table B-1. Guidance and Requirements to Deliverables Crosswalk - Retrieval and Disposal Mission Readiness-to-Proceed Memorandum.

\begin{tabular}{|c|c|c|}
\hline Guidance or Requirement & Status & Implementing Location \\
\hline $\begin{array}{l}\text { A.1 DOE Letter to H.J. Hatch, FDH, from W.J } \\
\text { Taylor, DOE, dated August } 8,1997,49757162 \mathrm{~A} \text { (36) } \\
\text { ITEM CHECKLIST) }\end{array}$ & & \\
\hline $\begin{array}{l}\text { 1. TWRS mission analysis is complete and consistent } \\
\text { with higher level plans and specifications. }\end{array}$ & $\mathrm{I}$ & Appendix A \\
\hline $\begin{array}{l}\text { 2. Requirements are identified, validated, and } \\
\text { documented. }\end{array}$ & $\mathrm{I}$ & Appendix A \\
\hline 3. Requirements are allocated to functions. & $\mathrm{I}$ & Appendix A \\
\hline $\begin{array}{l}\text { 4. Each activity is tied to and necessary to support a } \\
\text { contractual requirement. }\end{array}$ & $\mathrm{I}$ & Appendix A \\
\hline $\begin{array}{l}\text { 5. Architecture is defined based upon analyses of the } \\
\text { mission and the functions and requirements. }\end{array}$ & $\mathrm{I}$ & Appendix A \\
\hline $\begin{array}{l}\text { 6. All enabling assumptions have been formally } \\
\text { documented. Assumptions which have been replaced } \\
\text { with facts or decisions have been changed in } \\
\text { requirements documentation. }\end{array}$ & I & Appendix A \\
\hline $\begin{array}{l}\text { 7. Technical logic are complete at all levels; the } \\
\text { program makes sense logically; and lower level-logic } \\
\text { rolls up properly to higher-level logic. }\end{array}$ & $\mathrm{I}$ & Appendix A \\
\hline $\begin{array}{l}\text { 8. Operations plans that describe how the PHMC team } \\
\text { will execute the tech baseline have been prepared for } \\
\text { all projects and are supported by lower-tier plans. The } \\
\text { operation plans are consistent with MYWP and } \\
\text { LCAM. Ops. and Maintenance. plans are integrated. }\end{array}$ & I & Appendix A \\
\hline $\begin{array}{l}\text { 9. System boundaries and interfaces with other } \\
\text { organizations and programs/projects are defined. }\end{array}$ & $\mathrm{I}$ & Appendix A \\
\hline $\begin{array}{l}\text { 10. Interface control documents have been prepared, } \\
\text { DOE comments have been resolved, issues have been } \\
\text { addressed, and approved interfaces are managed. }\end{array}$ & $\mathrm{I}$ & Appendix A \\
\hline $\begin{array}{l}\text { 11. Waste feed plans and implementing actions and } \\
\text { procedures are on track. }\end{array}$ & $\mathrm{I}$ & Appendix A \\
\hline $\begin{array}{l}\text { 12. Infrastructure support plan and implementing } \\
\text { actions and procedures are on track. }\end{array}$ & $\mathrm{I}$ & Appendix A \\
\hline $\begin{array}{l}\text { 13. Immobilized waste product project plans and } \\
\text { implementing actions and procedures are on track. }\end{array}$ & $\mathrm{I}$ & Appendix $\dot{A}$ \\
\hline
\end{tabular}


Table B-1. Guidance and Requirements to Deliverables Crosswalk - Retrieval and Disposal Mission Readiness-to-Proceed Memorandum.

\begin{tabular}{|c|c|c|}
\hline Guidance or Requirement & Status & Implementing Location \\
\hline $\begin{array}{l}\text { 14. Plans and implementing actions that support } \\
\text { privatization contract requirements for dealing with } \\
\text { waste processing plan by-products including } \\
\text { interfacing with other contractors are on track. }\end{array}$ & I & Appendix A \\
\hline $\begin{array}{l}\text { 15. Technical risks have been identified and are being } \\
\text { managed. }\end{array}$ & I & Appendix A \\
\hline $\begin{array}{l}\text { 16. The technical baseline is complete and defensible, } \\
\text { and represents best value to the government. }\end{array}$ & $\mathrm{I}$ & Appendix A \\
\hline $\begin{array}{l}\text { 17. The technical baseline under configuration } \\
\text { control. }\end{array}$ & $\mathrm{I}$ & Appendix A \\
\hline $\begin{array}{l}\text { 18. System reliability, availability, and maintainability } \\
\text { have been assessed and are sufficient to support } \\
\text { processing rate requirements. }\end{array}$ & $I$ & Appendix A \\
\hline $\begin{array}{l}\text { 19. The physical integrity of existing systems, } \\
\text { structures, and components has been verified. }\end{array}$ & $\mathrm{I}$ & Appendix A \\
\hline $\begin{array}{l}\text { 20. Waste has been characterized as necessary to } \\
\text { satisfy all data quality objectives. }\end{array}$ & I & Appendix A \\
\hline $\begin{array}{l}\text { 21. The ability of the PHMC team to support } \\
\text { alternatives other than the baseline has been evaluated } \\
\text { from a technical perspective. }\end{array}$ & $\mathrm{I}$ & Appendix A \\
\hline $\begin{array}{l}\text { 22. Resource-loaded estimates have been completed } \\
\text { for all activities. }\end{array}$ & $\mathrm{I}$ & Appendix A \\
\hline $\begin{array}{l}\text { 23. The critical path is identified and float has been } \\
\text { calculated. }\end{array}$ & $\mathrm{I}$ & Appendix A \\
\hline 24. Activities have been properly funded. & $\mathrm{I}$ & Section 4.3.4 and Appendix A \\
\hline $\begin{array}{l}\text { 25. Analysis of budget against resource requirements } \\
\text { has been completed. }\end{array}$ & $\mathrm{I}$ & Appendix A \\
\hline $\begin{array}{l}\text { 26. There is agreement among scope, budget, and } \\
\text { schedule. The scope of work can be performed within } \\
\text { budget and on schedule. }\end{array}$ & $\mathrm{I}$ & $\begin{array}{l}\text { Sections } 3.0 ; 4.2 .3 ; 4.3 .4 \text {; and Appendix } \\
\text { A }\end{array}$ \\
\hline $\begin{array}{l}\text { 27. Schedule risk has been identified and is being } \\
\text { managed. }\end{array}$ & $\mathrm{I}$ & Appendix A \\
\hline $\begin{array}{l}\text { 28. The programmatic baseline is under configuration } \\
\text { management and a change control system is } \\
\text { implemented. }\end{array}$ & I & Appendix A \\
\hline $\begin{array}{l}\text { 29. The ability to support alternatives other than the } \\
\text { baseline has been evaluated from a programmatic } \\
\text { perspective. }\end{array}$ & I & Appendix A \\
\hline
\end{tabular}


Table B-1. Guidance and Requirements to Deliverables Crosswalk - Retrieval and Disposal Mission Readiness-to-Proceed Memorandum.

\begin{tabular}{|c|c|c|}
\hline Guidance or Requirement & Status & Implementing Location \\
\hline $\begin{array}{l}\text { 30. Management systems are in place to track and } \\
\text { report cost, schedule, and technical performance and } \\
\text { take appropriate corrective actions. }\end{array}$ & I & Appendix A \\
\hline $\begin{array}{l}\text { 31. Program planning encompasses all organizations } \\
\text { and facilities, including support, that contribute to the } \\
\text { mission. }\end{array}$ & $\mathrm{I}$ & Section 4.2.3 and Appendix A \\
\hline $\begin{array}{l}\text { 32. Environmental permits and safety authorization } \\
\text { bases are in place as required for authorization-to- } \\
\text { proceed decision. }\end{array}$ & I & Appendix A \\
\hline 33. Staff, including managers, are in place and trained. & $\mathrm{I}$ & Sections $3.0 ; 4.2 .3 ; 5.4$; and Appendix A \\
\hline $\begin{array}{l}\text { 34. A records management program, including } \\
\text { technical drawings, has been implemented. }\end{array}$ & $\mathrm{I}$ & Appendix A \\
\hline $\begin{array}{l}\text { 35. A risk and decision management program has } \\
\text { been implemented at all levels. }\end{array}$ & I & Appendix A \\
\hline $\begin{array}{l}\text { 36. The PMHC team has prepared a readiness-to- } \\
\text { proceed memorandum and has identified deficiencies } \\
\text { and corrective actions, including funding, necessary to } \\
\text { support privatization. }\end{array}$ & I & $\begin{array}{l}\text { Sections } 1.2 ; 4.3 .4 ; 4.3 .3 ; \text { and Appendix } \\
\text { A }\end{array}$ \\
\hline $\begin{array}{l}\text { A. } \text { DOE Letter to H. J Hatch, FDH, from W. J, } \\
\text { Taylor, DOE, dated August } 8,1997,49757162 \mathrm{~A} \\
\text { (BODY OF TEXT) }\end{array}$ & & 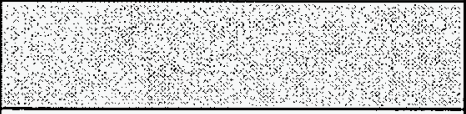 \\
\hline $\begin{array}{l}\text { General PHMC Responsibilities from RL's 8/8/97 } \\
\text { letter, Section 2.1 }\end{array}$ & . & \\
\hline 4. Work in the technical baseline can be performed & $\mathrm{I}$ & Sections 3.0 and 5.4 \\
\hline $\begin{array}{l}\text { 8. Management systems and program controls are } \\
\text { established }\end{array}$ & I & $\begin{array}{l}\text { Sections } 3.0 ; 4.2 .2 ; 5.4 ; \text { and Appendix } \\
\text { A, Item } 30\end{array}$ \\
\hline \multicolumn{3}{|l|}{$\begin{array}{l}\text { Specific Responsibility from RL's August 8, } 1997 \\
\text { letter, Section } 2.2\end{array}$} \\
\hline $\begin{array}{l}\text { 1. Waste feed can be provided in the specified amount } \\
\text { to the specified place at the specified time }\end{array}$ & $\mathrm{I}$ & Sections $1.2 ; 2.0 ; 3.0$ and 5 \\
\hline $\begin{array}{l}\text { 2. Infrastructure support can be provided to the private } \\
\text { vendors as specified in the final privatization contract } \\
\text { and ICDs }\end{array}$ & I & Sections $1.2 ; 2.0 ; 3.0$ and 5 \\
\hline $\begin{array}{l}\text { 3. PHMC Team will be prepared for receiving, storing } \\
\text { and disposing of immobilized waste products }\end{array}$ & I & Sections $1.2 ; 2.0 ; 3.0$ and 5 \\
\hline $\begin{array}{l}\text { 4. PHMC will be prepared for receiving, managing, } \\
\text { treating and disposing of by-products from private } \\
\text { contractors }\end{array}$ & I & Sections $1.2 ; 2.0 ; 3.0$ and 5 \\
\hline
\end{tabular}


Table B-1. Guidance and Requirements to Deliverables Crosswalk - Retrieval and Disposal Mission Readiness-to-Proceed Memorandum.

\begin{tabular}{|c|c|c|}
\hline Guidance or Requirement & Status & Implementing Location \\
\hline $\begin{array}{l}\text { 5. A plan-of-action exists that assesses the ability of } \\
\text { the PHMC Team to proceed with Phase 1B } \\
\end{array}$ & I & Section 4.0 of the 10/31/97 RTP Plan \\
\hline $\begin{array}{l}\text { 7. All required administrative actions are understood } \\
\text { and planned }\end{array}$ & I & Section 4.2 .3 \\
\hline $\begin{array}{l}\text { 8. A Readiness-to-Proceed Memorandum has been } \\
\text { submitted }\end{array}$ & I & Entire Memorandum \\
\hline $\begin{array}{l}\text { A.3 DOE Letter H. J Hatch, FDH, from William J. } \\
\text { Taylor, DOE, dated December } 2,1997, \# 9761291 \text {, }\end{array}$ & 4 & \\
\hline $\begin{array}{l}\text { 1. Describe how the PHMC Team will assess their } \\
\text { readiness. }\end{array}$ & I & Section 4 \\
\hline $\begin{array}{l}\text { 2. Describe how the PHMC Team will demonstrate } \\
\text { their readiness. }\end{array}$ & I & Section 4 \\
\hline $\begin{array}{l}\text { 4. Assess the Team's ability to successfully execute } \\
\text { the plans. }\end{array}$ & I & Section 5.4 \\
\hline $\begin{array}{l}\text { 5. Provide specific information to address the ten } \\
\text { areas in Paragraph } 4.2 .4 \text { of the August } 8 \text { DOE letter of } \\
\text { direction }\end{array}$ & . & \\
\hline $\begin{array}{l}\text { a. Explain FDH's willingness to receive solid } \\
\text { radioactive waste }\end{array}$ & I & Sections 2.0 and 3.0 \\
\hline $\begin{array}{l}\text { b. Explain FDH's willingness to receive radioactive } \\
\text { dangerous liquid effluents }\end{array}$ & I & Sections 2.0 and 3.0 \\
\hline $\begin{array}{l}\text { c. Explain FDH's willingness to receive non-routine } \\
\text { high-level solid wastes. }\end{array}$ & $\mathrm{I}$ & Sections 2.0 and 3.0 \\
\hline $\begin{array}{l}\text { d. Address adequate planning of the solid waste } \\
\text { complex }\end{array}$ & $\dot{\mathrm{I}}$ & Sections 3.0 and 4.2 .3 \\
\hline e. Address adequate planning of LERF/ETF & $\mathrm{I}$ & Sections 3.0 and 4.2 .3 \\
\hline f. Address adequate planning of TEDF & I & Sections 3.0 and 4.2 .3 \\
\hline g. Address adequate planning of similar facilities & I & Sections 3.0 and 4.2 .3 \\
\hline $\begin{array}{l}\text { 9. Identify the decisions that are being deferred, when } \\
\text { they are projected to be finalized and the assumptions } \\
\text { relating to those decisions. }\end{array}$ & I & Section 4.2.1 \\
\hline 10. Make plans for internal reviews available to DOE. & . & \\
\hline $\begin{array}{l}\text { b. Include a list of (internal review team) members in } \\
\text { the internal review plans provided to DOE }\end{array}$ & $\mathrm{I}$ & Section 4.3.3 \\
\hline $\begin{array}{l}\text { c. Include the review criteria and approach in the } \\
\text { internal review plans provided to DOE }\end{array}$ & $\mathrm{I}$ & Section 4.3 .3 \\
\hline
\end{tabular}


Table B-1. Guidance and Requirements to Deliverables Crosswalk - Retrieval and Disposal Mission Readiness-to-Proceed Memorandum.

\begin{tabular}{|c|c|c|}
\hline Guidance or Requirement & Status & Implementing Location \\
\hline $\begin{array}{l}\text { d. Include the checklists used by the review teams in } \\
\text { the internal review plans provided to DOE }\end{array}$ & $\mathrm{I}$ & Section 4.3.3 \\
\hline $\begin{array}{l}\text { e. Include the results and recommended actions in the } \\
\text { internal review plans provided to DOE }\end{array}$ & $I$ & Section 4.3.3 \\
\hline $\begin{array}{l}\text { D. Detailed Tnstructions for Assessment of RTP } \\
\text { Appendix C, November 14, } 1997\end{array}$ & +4 & \\
\hline 5. Show the ability to meet the June, 2002 hot start & $I$ & Sections 3,4 , and 5 \\
\hline $\begin{array}{l}\text { 20. Describe the overall risk of proceeding with Phase } \\
\text { 1B, individual risks, and risk handling actions for each. }\end{array}$ & I & $\begin{array}{l}\text { Sections } 4.3 .5,4.3 .4,5.5 \text {, and } \\
\text { Attachment I }\end{array}$ \\
\hline $\begin{array}{l}\text { D. } 2 \text { Plan for Determining PHMC Team's RTP for } \\
\text { Waste Feed Delivery (Table 2). }\end{array}$ & +2 & \\
\hline $\begin{array}{l}\text { PHMC provide deliverables necessary to support RTP, } \\
\text { as follows: }\end{array}$ & . & \\
\hline 10. Initial RTP Memorandum & $\mathrm{I}$ & Section 1.2 of the $10 / 31 / 97$ RTP plan \\
\hline 11. Final RTP Memorandum & I & Entire RTP Memorandum \\
\hline $\begin{array}{l}\text { D. } 4 \text { PHMC RTP, Approach for the Evaluation of } \\
\text { Administrative Readiness, December } 4,1997\end{array}$ & 0 & \\
\hline $\begin{array}{l}\text { 3. Sponsorship - Sponsorship begins with the DOE } \\
\text { Richland Ops Office Manager, flows to the } \\
\text { PHMC/PHMC Team, to the integrated contractors and } \\
\text { ends where the work is actually performed. }\end{array}$ & I & Section 5.4 \\
\hline $\begin{array}{l}\text { 4. Ownership - Systems, processes and behaviors } \\
\text { promote outcome-ownership, buy-in of the approach to } \\
\text { achieve the outcome, commitment to success and } \\
\text { individual involvement. }\end{array}$ & I & Section 5.4 \\
\hline $\begin{array}{l}\text { D.5 Draft Plan for Determining RTP for } \\
\text { Infrastructure \& Byproducts Delivery }\end{array}$ & $\%$ & \\
\hline 5. Show the ability to meet the June, 2002 hot start. & $\mathrm{I}$ & Sections $3.0,4.2 .3,4.3 .3$ and 4.3 .4 \\
\hline $\begin{array}{l}\text { D.8 Draft Plan for Determining RTP for } \\
\text { Infrastructure \& Byproducts Delivery, Appendix } \\
\text { C, Infrastructure (Managenent Baseline) } \\
\text { Checklist. }\end{array}$ & & \\
\hline $\begin{array}{l}\text { 51. Show that the RTP Memorandum identifies } \\
\text { deficiencies consistent with risk list and corrective } \\
\text { actions consistent with Project/CRML Risk Lists. } \\
(2.1 .1-2.1 .5)\end{array}$ & I & Sections 4.3.3, 4.3.4, and Attachment 1 \\
\hline
\end{tabular}


Table B-1. Guidance and Requirements to Deliverables Crosswalk - Retrieval and Disposal Mission Readiness-to-Proceed Memorandum.

\begin{tabular}{|c|c|c|}
\hline Guidance or Requirement & Status & Implementing Location \\
\hline $\begin{array}{l}\text { D.11 Draft Plan for Determining RTP for } \\
\text { Infrastructure \& Byproducts Delivery, Appendix E, } \\
\text { Infrastructure Feed Tank Transfer (Management } \\
\text { Baseline) Ghecklist. }\end{array}$ & & \\
\hline $\begin{array}{l}\text { 95. Show that the RTP Memorandum identifies } \\
\text { deficiencies consistent with risk list and corrective } \\
\text { actions consistent with Project/CRML Risk Lists. } \\
(2.1 .1-2.1 .5)\end{array}$ & I & $\begin{array}{l}\text { Sections } 4.3 .3,4.3 .4,5.5 .2 \text {, and } \\
\text { Attachment } 1\end{array}$ \\
\hline
\end{tabular}


HNF-2019 Rev 0

\section{APPENDIX C}

TEN MONTHLY REVIEW AREAS

FROM PARAGRAPH 4.2.4 OF

THE AUGUST 8, 1997, U.S. DEPARTMENT OF ENERGY

GUIDANCE LETTER (Taylor 1997) 
HNF-2019 Rev 0

This page intentionally left blank.

C-ii 
Ten Monthly Review Areas from Paragraph 4.2.4 of the August 8, 1997

U.S. Department of Énergy Guidance Letter

\begin{tabular}{|c|c|c|c|c|}
\hline No. & Description & Document & $\begin{array}{c}\text { Crosswalk } \\
\text { ack to } \\
\text { 36.ltem } \\
\text { Checklist } \\
\text { from } 8 / 8 \text { Letter } \\
\text { (Item \#) }\end{array}$ & Status \\
\hline 1 & $\begin{array}{l}\text { Interface } \\
\text { Control } \\
\text { Documents }\end{array}$ & $\begin{array}{l}\text { 1) HNF-SP-1227, Compliation of } \\
\text { Interface Control Documents, } \\
\text { Recommendations to Resolve Open } \\
\text { Issues, Plans to Resolve All Remaining } \\
\text { Interface Issues. } \\
\text { 2) LMHC Internal Memorandum, } \\
\text { \#73600-97-PSS-001, Identificatication } \\
\text { and Control of TWRS Interfaces }\end{array}$ & 9 & Green \\
\hline 2 & $\begin{array}{l}\text { Waste feed vs } \\
\text { cost, schedule } \\
\text { and } \\
\text { performance } \\
\text { requirements }\end{array}$ & $\begin{array}{l}\text { 1) HNF-SD-WM-SP-012, TWRS } \\
\text { Operations and Utilization Plan } \\
\text { 2) HNF-1881, TWRS Retrieval and } \\
\text { Disposal Mission Waste Feed Delivery } \\
\text { Plan } \\
\text { 3) HNF-1946, TWRS Retrieval and } \\
\text { Disposal Mission Initial Updated } \\
\text { Baseline Summary }\end{array}$ & 11 & Green \\
\hline 3 & $\begin{array}{l}\text { Construction vs } \\
\text { cost, schedule } \\
\text { and } \\
\text { performance } \\
\text { requirements }\end{array}$ & $\begin{array}{l}\text { 1) HNF-1882, TWRS Retrieval and } \\
\text { Disposal Mission Infrastructure Plan } \\
\text { 2) HNF-1517, TWRS Retieval and } \\
\text { Disposal Mission Immobilized Low- } \\
\text { Activity Waste Disposal Plan } \\
\text { 3) HNF-1751, TWRS Retrieval and } \\
\text { Disposal Mission Immobilized High-Level } \\
\text { Waste Storage Plan } \\
\text { 4) HNF-1901, TWRS Retrieval and } \\
\text { Disposal Mission Technical Baseline } \\
\text { Summary Description } \\
\text { 5) HNF-SD-WM-008, TWRS Mission } \\
\text { Analysis Report } \\
\text { 6) HNF-1946, TWRS Retrieval and } \\
\text { Disposal Mission Initial Updated } \\
\text { Summary }\end{array}$ & 12,13 & Green \\
\hline
\end{tabular}


HNF-2019 Rev 0

Ten Monthly Review Areas from Paragraph 4.2.4 of the August 8, 1997

U.S. Department of Energy Guidance Letter

\begin{tabular}{|c|c|c|c|c|}
\hline No. & Description & Document & $\begin{array}{c}\text { Crosswalk } \\
\text { ack to } \\
\text { 36 Item } \\
\text { Checklist } \\
\text { from } 8 / 8 \text { Letter } \\
\text { (Item \#) }\end{array}$ & Status \\
\hline 4 & $\begin{array}{l}\text { Systems } \\
\text { engineering } \\
\text { technical } \\
\text { baseline as } \\
\text { reflected in the } \\
\text { Mission } \\
\text { Analysis and } \\
\text { Functions and } \\
\text { Requirements } \\
\text { database }\end{array}$ & $\begin{array}{l}\text { 1) HNF-1901, TWRS Retrieval and } \\
\text { Disposal Mission Technical Baseline } \\
\text { Summary Description } \\
\text { 2) HNF-SD-WM-008, TWRS Mission } \\
\text { Analysis Report }\end{array}$ & 16 & Green \\
\hline 5 & $\begin{array}{l}\text { Enviromental } \\
\text { permits }\end{array}$ & $\begin{array}{l}\text { 1) HNF-1773, Environmental Program } \\
\text { Plan } \\
\text { 2) HNF-1946, TWRS Retrieval and } \\
\text { Disposal Mission Initial Updated } \\
\text { Baseline Summary }\end{array}$ & 32 & Green \\
\hline 6 & $\begin{array}{l}\text { Authorization } \\
\text { and safety bases }\end{array}$ & $\begin{array}{l}\text { 1) HNF-1722, TWRS Retrieval } \\
\text { Authorization Basis Amendment Task } \\
\text { Plan } \\
\text { 2) HNF-1946, TWRS Retrieval and } \\
\text { Disposal Mission Initial Updated } \\
\text { Baseline Summary }\end{array}$ & 32 & Green \\
\hline 7 & $\begin{array}{l}\text { Operations and } \\
\text { maintenance } \\
\text { plans }\end{array}$ & $\begin{array}{l}\text { HNF-1883, TWRS Program Plan } \\
\text { (Appendix A and Appendix B) }\end{array}$ & 31 & Green \\
\hline 8 & Certified staff & HNF-1883, TWRS Program Plan & 33 & Green \\
\hline 9 & $\begin{array}{l}\text { Records } \\
\text { management, } \\
\text { including } \\
\text { verification of } \\
\text { "as built" } \\
\text { drawings }\end{array}$ & $\begin{array}{l}\text { 1) HNF-1900, TWRS Configuration } \\
\text { Managment Implementation Plan } \\
\text { 2) HNF-1901, TWRS Retrieval and } \\
\text { Disposal Mission Technical Baseling } \\
\text { Summary Description } \\
\text { 3) HNF-1883, TWRS Program Plan }\end{array}$ & 17,34 & Green \\
\hline
\end{tabular}


Ten Monthly Review Areas from Paragraph 4.2.4 of the August 8, 1997

U.S. Department of Energy Guidance Letter

\begin{tabular}{|c|c|c|c|c|}
\hline No. & Description & Document & $\begin{array}{c}\text { Crosswalk } \\
\text { ack to } \\
36 \text { Item } \\
\text { Checklist } \\
\text { from } 8 / 8 \text { Letter } \\
\text { (Item \#) }\end{array}$ & Status \\
\hline 10 & $\begin{array}{l}\text { Operational } \\
\text { Readiness } \\
\text { Review } \\
\text { preparation and } \\
\text { its } \\
\text { implementation }\end{array}$ & $\begin{array}{l}\text { 1) HNF-1946, TWRS Retrieval and } \\
\text { Disposal Mission Intitial Updated } \\
\text { Baseline Summary } \\
\text { 2) HNF-SD-WM-SP-012, TWRS } \\
\text { Operations and Utilization Plan } \\
\text { 3) HNF-1881, TWRS Retrieval and } \\
\text { Disposal Mission Waste Feed Delivery } \\
\text { Plan } \\
\text { 4) HNF-1946, TWRS Retrieval and } \\
\text { Disposal Mission Initial Updated } \\
\text { Baseline Summary } \\
\text { 5) HNF-1882, TWRS Retrieval and } \\
\text { Disposal Mission Infrastruture Plan } \\
\text { 6) HNF-1517, TWRS Retrieval and } \\
\text { Disposal Mission Immobilized Low- } \\
\text { Activity Waste Disposal Plan } \\
\text { 7) HNF-1751, TWRS Retrieval and } \\
\text { Disposal Mission Immobilized High-Level } \\
\text { Waste Storage Plan } \\
\text { 8) HNF-1901, TWRS Retrieval and } \\
\text { Disposal Mission Technical Baseline } \\
\text { Summary Description } \\
\text { 9) HNF-SD-WM-008, TWRS Mission } \\
\text { Analysis Report }\end{array}$ & $8,11,12,13$ & Green \\
\hline
\end{tabular}

Source: Taylor, W. J. 1977, Contract Number DE-AC06-96RL13200, Tank Waste Remediation System (TWRS) Privatization - Hanford Contractors Readiness-to-Proceed, (letter 97-WDD-129 to H. J. Hatch, Fluor Daniel Hanford, Inc., August 8), U.S. Department of Energy, Richland Operations Office, Richland, Washington. 
HNF-2019 Rev 0

This page intentionally left blank.

C-4 
HNF-2019 Rev 0

ATTACHMENT 1

TANK WASTE REMEDIATION SYSTEM RETRIEVAL AND DISPOSAL MISSION CRITICAL RISK LIST 
HNF-2019 Rev 0

This page intentionally left blank.

Att-ii 


\section{TERMS}

$\begin{array}{ll}\text { CRL } & \text { Critical Risk List } \\ \text { CSB } & \text { canister storage building } \\ \text { HLW } & \text { high-level waste } \\ \text { ICD } & \text { Interface Control Document } \\ \text { ILAW } & \text { immobilized low activity waste } \\ \text { PHMC } & \text { Project Hanford Management Contract } \\ \text { TWRS } & \text { Tank Waste Remediation System }\end{array}$


HNF-2019 Rev 0

This page intentionally left blank. 


\section{INTRODUCTION}

The Critical Risk List (CRL) represents a compilation of key risks to the Tank Waste Remediation System (TWRS) Project which, if they should occur, could cause considerable schedule delay and/or require significant resources to fix. These critical risks have been lifted primarily from the Technical Basis Review documents. Additionally, other sources such as the management assessment, the financial risk analysis, and the independent assessment, were used to identify risks. These critical risks represent the "significant few" that require concerted and ongoing senior management attention. They have been grouped into four major areas: General, Waste Feed Delivery (on schedule, within specification, sufficient quantity), Products (Immobilized Low-Activity Waste [ILAW]/Immobilized High-Level Waste [IHLW], intermediate), and Infrastructure, as shown on the following page.

Risks are also associated with planning or enabling assumptions; thus, a cross-reference of critical risks and key enabling assumptions is provided in this table. Each enabling assumption is logically based, but may be proven invalid through final contract negotiations or changes in policy or regulations. Unwanted events (risks) resulting from invalidation of an enabling assumption may be severe, but cannot be anticipated or mitigated. HNF-1945, Tank Waste Remediation System Retrieval and Disposal Mission Key Enabling Assumptions provides actions to confirm enabling assumptions (Baldwin et al. 1998). The Critical Risk List recommends actions to reduce potential risk or cost to the government.

This CRL is a snapshot in time and represents an upper-level summary from more detailed risk lists and the risk management process. Using the HNF-SD-WM-PMP-018, Tank Waste Remediation System Risk Management Plan (Zimmerman 1998), a complete list of risks with risk values, mitigating actions, and other information is being used by the Project Hanford Management Contract (PHMC) team as a management tool and is periodically updated and statused. Assumptions that become facts and risks that are mitigated will be shown as completed.

Each of the table headings is briefly explained below.

- Assumption or Issue - a statement regarding the technical or programmatic status of the TWRS Project that, for purposes of planning or enabling, is accepted as being factual.

- Risk - an unwanted event that has some probability of occurring with some level of resulting consequence. 
- Mitigating Activities - the interceding actions that are taken to lower the probability of an unwanted event and/or to reduce the severity of the consequences should the unwanted event occur. (Note that no mitigating activities are listed for planning assumptions. Changes to the cost and schedule baseline will be required through Change Control if planning assumptions change.)

- Recommendations - technical or programmatic (contractual) changes that the PHMC team is requesting the U.S. Department of Energy, Richland Operations Office (RL) consider to reduce a risk or reduce cost associated with mitigating risk. 


\section{Major Areas of TWRS Retrieval and Disposal Mission Risk}

General:

Privatization Schedule (CRL-1)

Final Interface Control Documents (CRL-2)

Budget Validation (CRL-3)

Regulatory Authority (CRL-4)

Health and Safety Issue Resolution (CRL-10)

Unplanned Radiological Exposures (CRL-11)

Support Facility Availability (CRL-12)

Watch List Tanks (CRL-14)

Insufficient Regulatory Agency Staffing (CRL-29)

Waste Feed Delivery

On Schedule:

AP-106/108 Interfaces (CRL-5)

AP Tank Farm Conflicts (CRL-6)

Mixing and Retrieval System (CRL-8)

Facility Processing Rates (CRL-9)

Health and Safety Issue Resolution (CRL-10)

Concurrent Retrieval System Construction (CRL-13)

Watch List Tanks (CRL-14)

Private Contractor High-Level Waste Feed Tank Capacity (CRL-15)

Continuous Use of Double-shell Tanks (CRL-20)

Waste Certification Strategy Not Yet Defined (CRL-25)

Failure of Mixer or Transfer Pumps (CRL-28)

Insufficient Spare Parts. (CRL-30)

Plugged Transfer Lines (CRL-27)

Waste Feed Specification Disputes (CRL-31)

222S Laboratories (CRL-32)

Within Specification

Enhanced Sludge Washing Capabilities (CRL-21)

Waste Feed is Out-of-Specification (CRL-22)

Sufficient Quantity

Watch List Tanks (CRL-14)

102-SY/105-AW Waste Compatibility (CRL-23) 
HNF-2019 Rev 0

Products

ILAW/IHLW

Onsite Disposal of ILAW (CRL-16)

IHLW Volumes (CRL-17)

Canister Storage Building Vault Capacity (CRL-18)

Canister Storage Building Operations Schedule (CRL-19)

Projects W-465 and W-465 Completion Delays (CRL-26)

Intermediate Products

Separated Solids Returns (CRL-7)

Infrastructure

Duration of Private Contractor Facility Construction (CRL-24)

\section{REFERENCES}

\section{Public Law}

Public Law 101-510, National Defense Authorization Act for Fiscal Year 1991, Section 3137, "Wyden Bill," November 5, 1990.

\section{Documents}

Baldwin, J. H., T. J. McLaughlin, R. D. Potter, and R. L. Treat, 1998, Tank Waste Remediation System Retrieval and Disposal Mission Key Enabling Assumptions, HNF-1945, Rev. 0, prepared by Lockheed Martin Hanford Corporation for Fluor Daniel Hanford, Inc., Richland, Washington.

Kirkbride, R. A., G. K. Allen, P. J. Certa, A. F. Manuel, R. M. Orme, L. W. Shelton, E. J. Slaathaug, R. S. Wittman, G. T. MacLean, and D. L. Penwell (SESC), 1997, Tank Waste Remediation System Operation and Utilization Plan, HNF-SD-WM-SP-012, Rev. 0, Volumes I and II, prepared by Numatec Hanford Corporation for Fluor Daniel Hanford, Inc., Richland, Washington.

Zimmerman, B. D., 1998, Tank Waste Remediation System Risk Management Plan, HNF-SD-WM-PMP-018, Rev. 2, prepared by Lockheed Martin Hanford Corporation for Fluor Daniel Hanford, Inc., Richland, Washington. 
Tank Waste Retrieval System Retrieval and Disposal Mission Critical Risk List (9 Sheets)

\begin{tabular}{|c|c|c|c|c|c|}
\hline No. & Title & Assumption or issue & Risk & Mitigating activities & Recommendations \\
\hline 1 & Privatization Schedule & $\begin{array}{l}\text { The strategy for waste immobilization } \\
\text { will be implemented essentially as } \\
\text { described in the private contracts. } \\
\text { Most significantly, privatized hot } \\
\text { operations are assumed to start in June } \\
2002 \text { and end in May } 2011 \text {. (EA-1, } \\
\text { EA-3, EA-4) }\end{array}$ & $\begin{array}{l}\text { Private contractor contracts for } \\
\text { Phase IB may deviate from } \\
\text { specifications in the Phase A } \\
\text { contracts or from planning } \\
\text { assumptions made by the TWRS } \\
\text { Project contractor. }\end{array}$ & $\begin{array}{l}\text { No mitigating activities; changes to } \\
\text { contract requirements or planning } \\
\text { assumptions will require changes to } \\
\text { cost and schedule baseline. }\end{array}$ & $\begin{array}{l}\text { Review the impacts of proposed } \\
\text { changes to contract requirements or } \\
\text { planning assumptions well before } \\
\text { executing the Phase } 1 \mathrm{~B} \text { contracts. }\end{array}$ \\
\hline 2 & Final ICDs & $\begin{array}{l}\text { Current ICDs that define private } \\
\text { contractor and PHMC interface } \\
\text { responsibilities and obligations will } \\
\text { not be altered significantly when } \\
\text { incorporated into the Phase IB } \\
\text { contracts. (EA-8) }\end{array}$ & $\begin{array}{l}\text { The private contractors may require } \\
\text { significant modifications to the } \\
\text { ICDs. }\end{array}$ & $\begin{array}{l}\text { No mitigating activities; changes to } \\
\text { contract requirements or planning } \\
\text { assumptions will require changes to } \\
\text { cost and schedule baseline. }\end{array}$ & $\begin{array}{l}\text { Focus efforts on planned "what-if" } \\
\text { analyses in the February } 1998 \text { time } \\
\text { frame to provide the DOE with } \\
\text { impacts of proposed private contractor } \\
\text { changes. }\end{array}$ \\
\hline 3 & Budget Validation & $\begin{array}{l}\text { Budget validation to support } \\
\text { responsibilities for RL Waste Disposal } \\
\text { Division projects must be achieved in } \\
\text { time to support the Phase } 1 \text { schedule. } \\
\text { (EA-10) }\end{array}$ & $\begin{array}{l}\text { Budget validation may be delayed, } \\
\text { potentially causing unrecoverable } \\
\text { schedule slippage. }\end{array}$ & $\begin{array}{l}\text { No mitigating activities; changes to } \\
\text { contract requirements or planning } \\
\text { assumptions will require changes to } \\
\text { cost and schedule baseline. }\end{array}$ & $\begin{array}{l}\text { Provide accurate and timely budget } \\
\text { information to support the budget } \\
\text { process. }\end{array}$ \\
\hline 4 & Regulatory Authority & $\begin{array}{l}\text { Technical and budget planning are } \\
\text { based on safety regulations consistent } \\
\text { with DOE requirements because NRC } \\
\text { requirements are unknown at this } \\
\text { time. (EA-17) }\end{array}$ & $\begin{array}{l}\text { NRC may assume responsibility } \\
\text { during Phase } 1 \text { as the regulatory } \\
\text { authority, resulting in policy shifts. }\end{array}$ & $\begin{array}{l}\text { Review current NRC licensing } \\
\text { strategy and requirements; prepare } \\
\text { summary paper on impacts. }\end{array}$ & $\begin{array}{l}\text { Monitor plans for transition to NRC } \\
\text { ovcrsight and generate plans to } \\
\text { respond to new policy, as appropriate. }\end{array}$ \\
\hline
\end{tabular}


Tank Waste Retrieval System Retrieval and Disposal Mission Critical Risk List (9 Sheets)

\begin{tabular}{|c|c|c|c|c|c|c|}
\hline & No. & Title & Assumption or issue & Risk & Mitigating activities & Recommendations \\
\hline & 5 & $\begin{array}{l}\text { AP-106/108 Interfaces } \\
\text { (EA-5, EA-6, EA-7) }\end{array}$ & $\begin{array}{l}\text { Responsibility for operation and } \\
\text { maintenance of AP-106/108 will be } \\
\text { transferred to the private contractors } \\
\text { in FY } 1999 \text {. Agreements will be } \\
\text { negotiated with the private contractors } \\
\text { to establish interfaces of operational } \\
\text { systems and administrative controls } \\
\text { for the operation of these tanks, } \\
\text { including protocols for entering the } \\
\text { AP Tank Farms. These tanks will } \\
\text { contain wastes until waste transfers } \\
\text { free up other tank space to } \\
\text { accommodate the waste. }\end{array}$ & $\begin{array}{l}\text { The private contractors may refuse to } \\
\text { accept the tanks while they contain } \\
\text { waste or have not been ultrasonically } \\
\text { tested. } \\
\text { Agreements on protocols may not be } \\
\text { reached. }\end{array}$ & $\begin{array}{l}\text { No mitigating activities; changes to } \\
\text { contract requirements or planning } \\
\text { assumptions will result in changes to } \\
\text { cost and schedule baseline. }\end{array}$ & $\begin{array}{l}\text { The TWRS Project contractor should } \\
\text { retain operational and maintenance } \\
\text { control of the tanks, thus avoiding } \\
\text { inconsistent protocols in the AP Tank } \\
\text { Farm and liabilities associated with } \\
\text { installing new equipment in tanks } \\
\text { filled with wastes. Alternately, the } \\
\text { TWRS Project contractor retains } \\
\text { control through construction upgrades } \\
\text { and until delivery of first feed batch. }\end{array}$ \\
\hline & 6 & $\begin{array}{l}\text { AP Tank Farm } \\
\text { Conflicts }\end{array}$ & $\begin{array}{l}\text { Work conducted by the private } \\
\text { contractors and the TWRS Project } \\
\text { Contractor to upgrade tanks in the AP } \\
\text { Tank Farm can be accomplished in a } \\
\text { non-interference manner. }\end{array}$ & $\begin{array}{l}\text { Delays could result from physical } \\
\text { interferences of multiple } \\
\text { construction activities by several } \\
\text { parties in the limited space in AP } \\
\text { Tank Farm. }\end{array}$ & $\begin{array}{l}\text { Develop an integrated, detailed } \\
\text { schedule for AP Tank Farm work. }\end{array}$ & $\begin{array}{l}\text { Plan for additional oversight during } \\
\text { high-activity periods. TWRS Project } \\
\text { contractor retains control through } \\
\text { construction upgrades and until } \\
\text { delivery of first feed batch. }\end{array}$ \\
\hline 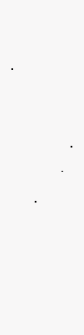 & 7 & $\begin{array}{l}\text { Separated Solids } \\
\text { Returns }\end{array}$ & $\begin{array}{l}\text { Private contractors will separate solids } \\
\text { in the LAW streams and return them } \\
\text { to the TWRS Project contractor at the } \\
\text { rate of approximately two 8,000-gal } \\
\text { transfers per LAW facility per year. } \\
\text { The LAW facility solids-return } \\
\text { streams will meet acceptance and } \\
\text { compatibility criteria necessary to } \\
\text { transfer the streams to AP-107 } \\
\text { through pipelines shared by the } \\
\text { TWRS Project Contractor and the } \\
\text { private contractor. The private } \\
\text { contractor will provide analytical data } \\
\text { which supports performance of these } \\
\text { transfers. (EA-25) }\end{array}$ & $\begin{array}{l}\text { Concentrations of return streams } \\
\text { may conflict with TWRS Project } \\
\text { Authorization Basis, cause } \\
\text { compatibility or criticality issues, } \\
\text { result in lines plugging, or cause } \\
\text { transfer line use conflicts. }\end{array}$ & $\begin{array}{l}\text { No mitigating activities; changes to } \\
\text { contract requirements or planning } \\
\text { assumptions will require changes to } \\
\text { cost and schedule baseline. }\end{array}$ & $\begin{array}{l}\text { Propose alternatives to DOE to lower } \\
\text { the risk: (1) pump LAW separated } \\
\text { solids directly to the } \\
\text { HLW facility for processing, or ( } 2 \text { ) } \\
\text { have the LAW-only private contractor } \\
\text { extend its return line directly to } \\
\text { AP-107. }\end{array}$ \\
\hline
\end{tabular}


Tank Waste Retrieval System Retrieval and Disposal Mission Critical Risk List (9 Sheets)

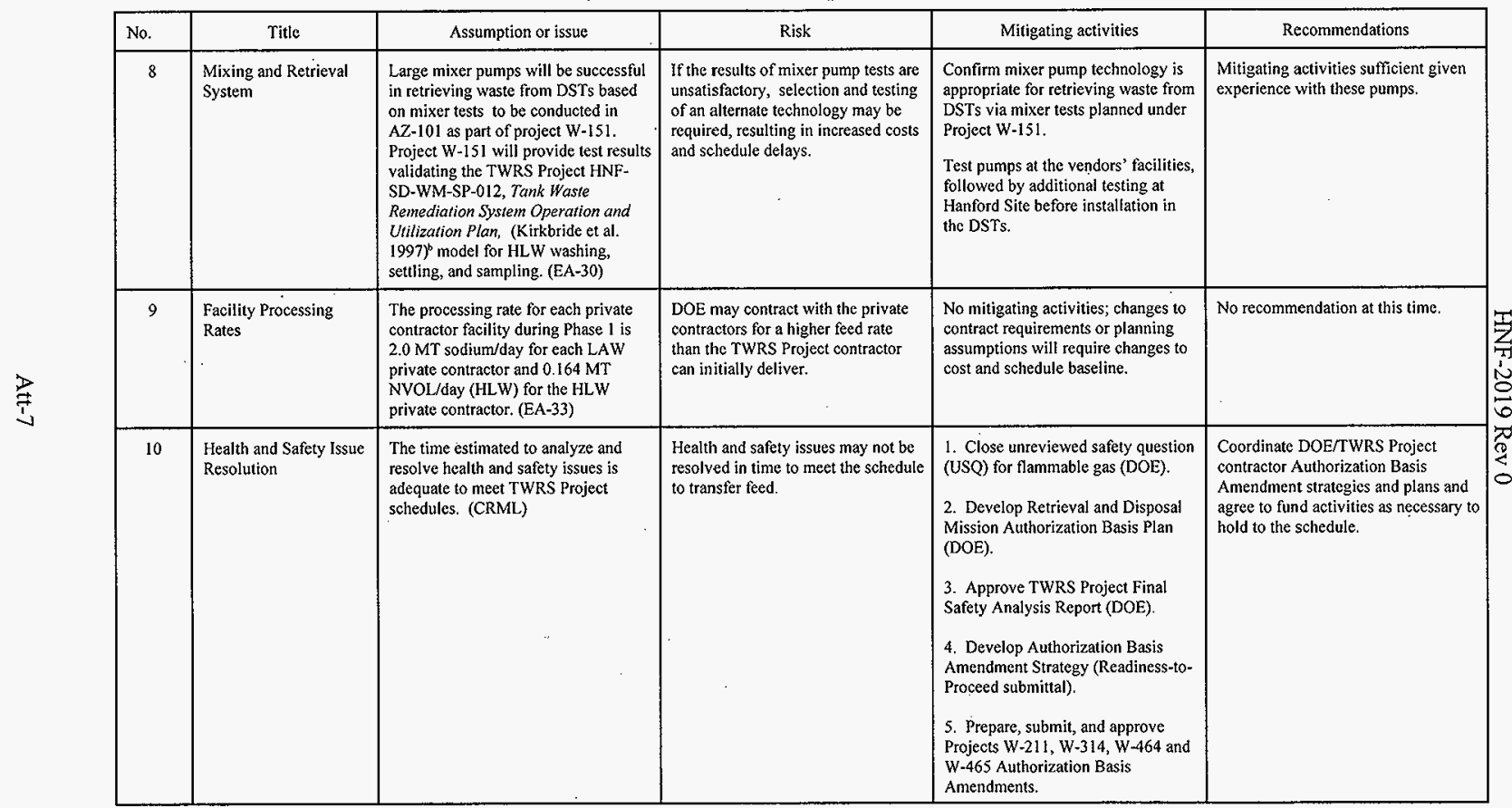


Tank Waste Retrieval System Retrieval and Disposal Mission Critical Risk List (9 Sheets)

\begin{tabular}{|c|c|c|c|c|c|}
\hline No. & Titte & Assumption or issue & Risk & Mitigating activities & Recommendations \\
\hline 11 & $\begin{array}{l}\text { Unplanned } \\
\text { Radiological Exposures }\end{array}$ & $\begin{array}{l}\text { Highly contaminated equipment must } \\
\text { be removed from the tanks to install } \\
\text { new or replacement equipment that } \\
\text { support Phase } 1 \text {. }\end{array}$ & $\begin{array}{l}\text { Unplanned radiological exposures } \\
\text { may occur. }\end{array}$ & $\begin{array}{l}\text { Use "mock-up" training at the Cold } \\
\text { Test Facility to allow practicing the } \\
\text { activities in normal and off-normal } \\
\text { situations. } \\
\text { Survey existing structures for } \\
\text { contamination to support design, } \\
\text { construction, and maintenance in } \\
\text { accordance with as-low-as- } \\
\text { reasonably achievable (ALARA) } \\
\text { principles. }\end{array}$ & Implement mitigating activities. \\
\hline 12 & $\begin{array}{l}\text { Support Facility } \\
\text { Availability }\end{array}$ & $\begin{array}{l}\text { The 242-A Evaporator will be } \\
\text { available to support waste processing } \\
\text { operations until the Phase } 2 \text { LAW } \\
\text { immobilization facility is in operation. } \\
\text { All upgrades necessary to extend the } \\
\text { operation of the evaporator through } \\
\text { FY } 2011 \text { will be completed by FY } \\
\text { 2005. (EA-29) }\end{array}$ & $\begin{array}{l}\text { Key facilities may not support the } \\
\text { mission due to obsolescence, } \\
\text { corrosion, or wear. }\end{array}$ & $\begin{array}{l}\text { Evaluate the design life of all } \\
\text { supporting facilities. Initiate timely } \\
\text { upgrades to ensure support facilities } \\
\text { are available throughout Phase } 1 \text {. }\end{array}$ & Implement mitigating activities. \\
\hline 13 & $\begin{array}{l}\text { Concurrent Retrieval } \\
\text { System Construction }\end{array}$ & $\begin{array}{l}\text { The schedule for installing retricval } \\
\text { systems requires concurrent } \\
\text { construction of four separate systems. }\end{array}$ & $\begin{array}{l}\text { The concurrent construction of four } \\
\text { retrieval systems may result in } \\
\text { logistical conflicts. }\end{array}$ & $\begin{array}{l}\text { Develop an integrated resource- } \\
\text { loaded schedule for installing } \\
\text { retrieval systems. }\end{array}$ & $\begin{array}{l}\text { Plan for additional oversight during } \\
\text { high-activity periods. }\end{array}$ \\
\hline
\end{tabular}


Tank Waste Retrieval System Retrieval and Disposal Mission Critical Risk List (9 Sheets)

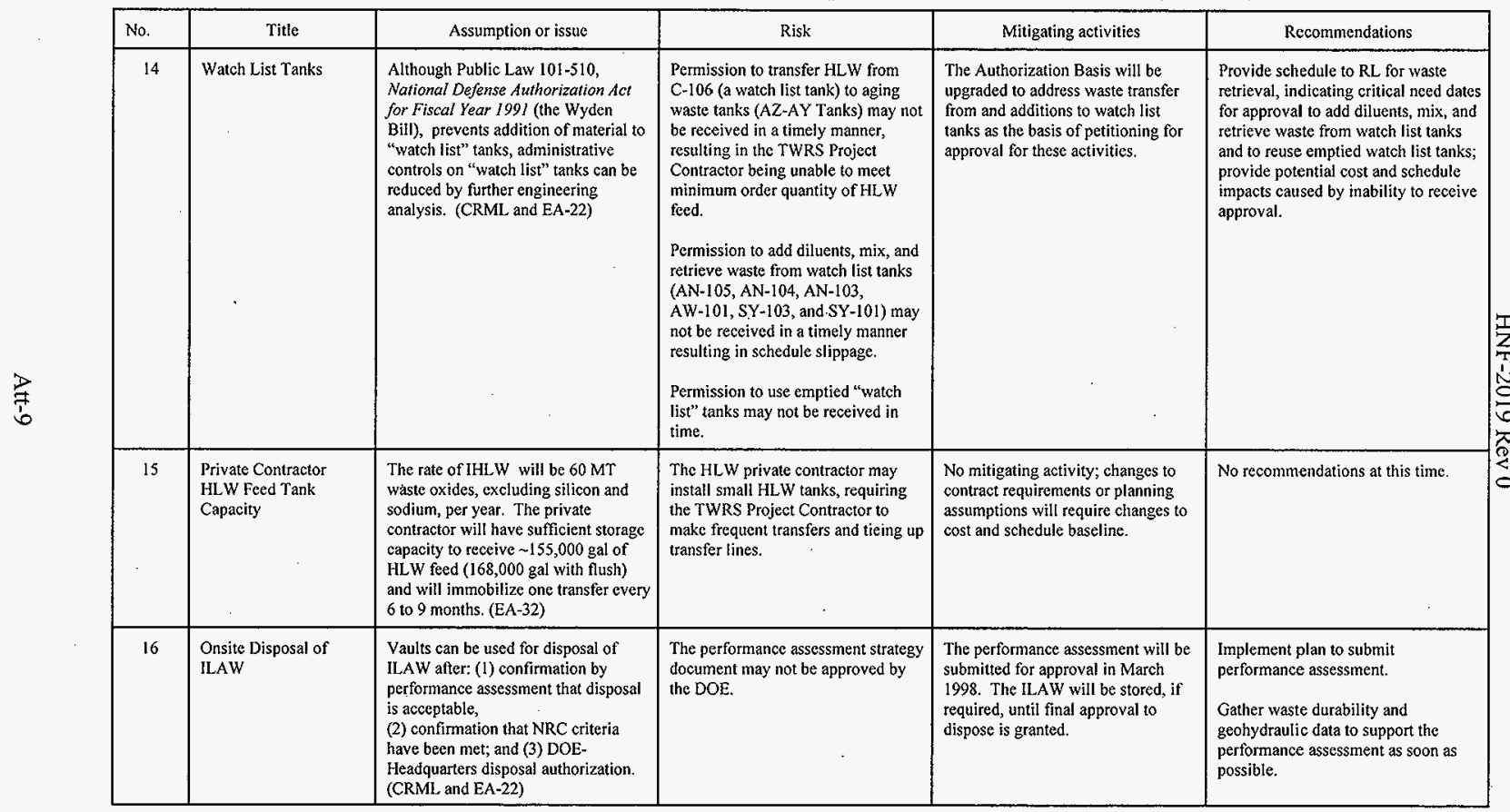


Tank Waste Retrieval System Retrieval and Disposal Mission Critical Risk List (9 Sheets)

\begin{tabular}{|c|c|c|c|c|c|}
\hline No. & Title & Assumption or issue & Risk & Mitigating activities & Recommendations \\
\hline 17 & IHLW Volumes & $\begin{array}{l}\text { The IHLW and ILAW volumes, } \\
\text { thermal loadings, and radiation doses } \\
\text { specified in the private contracts will } \\
\text { be attained. (EA-31) }\end{array}$ & $\begin{array}{l}\text { Storage and disposal facility } \\
\text { requirements may change for IHLW } \\
\text { and ILAW, respectively, if waste } \\
\text { oxide loading, radiation doses, } \\
\text { and/or thermal loading of the IHLW } \\
\text { and ILAW are significantly different } \\
\text { than currently specified. }\end{array}$ & $\begin{array}{l}\text { No mitigating activities; changes to } \\
\text { contract requirements or planning } \\
\text { assumptions will require changes to } \\
\text { cost and schedule baseline. }\end{array}$ & $\begin{array}{l}\text { Confirm IHLW and ILAW volume, } \\
\text { radiation doses, and thermal loading } \\
\text { estimate with private contractors. }\end{array}$ \\
\hline 18 & CSB Vault Capacity & $\begin{array}{l}\text { The two vaults of the CSB will have } \\
\text { adequate capacity for storing the } \\
\text { Phase I maximum order quantity of } \\
\text { IHLW. }\end{array}$ & $\begin{array}{l}\text { The two vaults of the CSB may not } \\
\text { have adequate capacity for the } \\
\text { Phase } 1 \text { maximum order quantity of } \\
\text { IHLW including quantities of } \\
\text { nonroutine waste. }\end{array}$ & $\begin{array}{l}\text { No mitigating activities; changes to } \\
\text { contract requirements or planning } \\
\text { assumptions will require changes to } \\
\text { cost and schedule baseline. }\end{array}$ & $\begin{array}{l}\text { Build added IHLW storage space if } \\
\text { required. }\end{array}$ \\
\hline$\underset{\overrightarrow{7}}{\stackrel{D}{7}}$ & $\begin{array}{l}\text { CSB Operations } \\
\text { Schedule }\end{array}$ & $\begin{array}{l}\text { The CSB will be completed by the } \\
\text { Spent Nuclear Fuel Project in time for } \\
\text { CSB vauts } 2 \& 3 \text { to be modified and } \\
\text { used for storage of IHLW. (EA-2) }\end{array}$ & $\begin{array}{l}\text { The schedule for CSB operations } \\
\text { may conflict with TWRS Project } \\
\text { activities to modify and utilize the } \\
\text { CSB for IHLW storage. }\end{array}$ & $\begin{array}{l}\text { Install tubes in vautts } 2 \& 3 \\
\text { concurrently with spent fuel } \\
\text { activities in the CSB using off shifts } \\
\text { and weekends. } \\
\text { Accelerate funding into FY } 1999 \text { to } \\
\text { allow tube procurement and stack } \\
\text { installation before hot fuel } \\
\text { operations. } \\
\text { Seck temporary storage space for } \\
\text { IHLW while awaiting completion of } \\
\text { the CSB. } \\
\text { Ensure equipment in CSB can handle } \\
\text { both DHLW and SNF canisters. }\end{array}$ & Implement mitigating activities. \\
\hline 20 & $\begin{array}{l}\text { Continuous Use of } \\
\text { DSTS }\end{array}$ & $\begin{array}{l}\text { The DST space required to execute } \\
\text { Phase } 1 \text { will be consistent with } \\
\text { planning assumptions in the Tank } \\
\text { Waste Remediation System Operation } \\
\text { and Utitization Plan (Kirkbride et al. } \\
\text { 1997). (EA-25) }\end{array}$ & $\begin{array}{l}\text { Any significant changes in rates of } \\
\text { salt well pumping or waste } \\
\text { generation by other facilities could } \\
\text { limit the ability to transfer waste } \\
\text { within the DST system. }\end{array}$ & $\begin{array}{l}\text { Carefully manage DST space with } \\
\text { Operational Waste Volume } \\
\text { Projections. }\end{array}$ & $\begin{array}{l}\text { Negotate relaxed feed envelopes. } \\
\text { This will simplify waste transfers and } \\
\text { provide additional DST space. }\end{array}$ \\
\hline
\end{tabular}


Tank Waste Retrieval System Rețrieval and Disposal Mission Critical Risk List (9 Sheets)

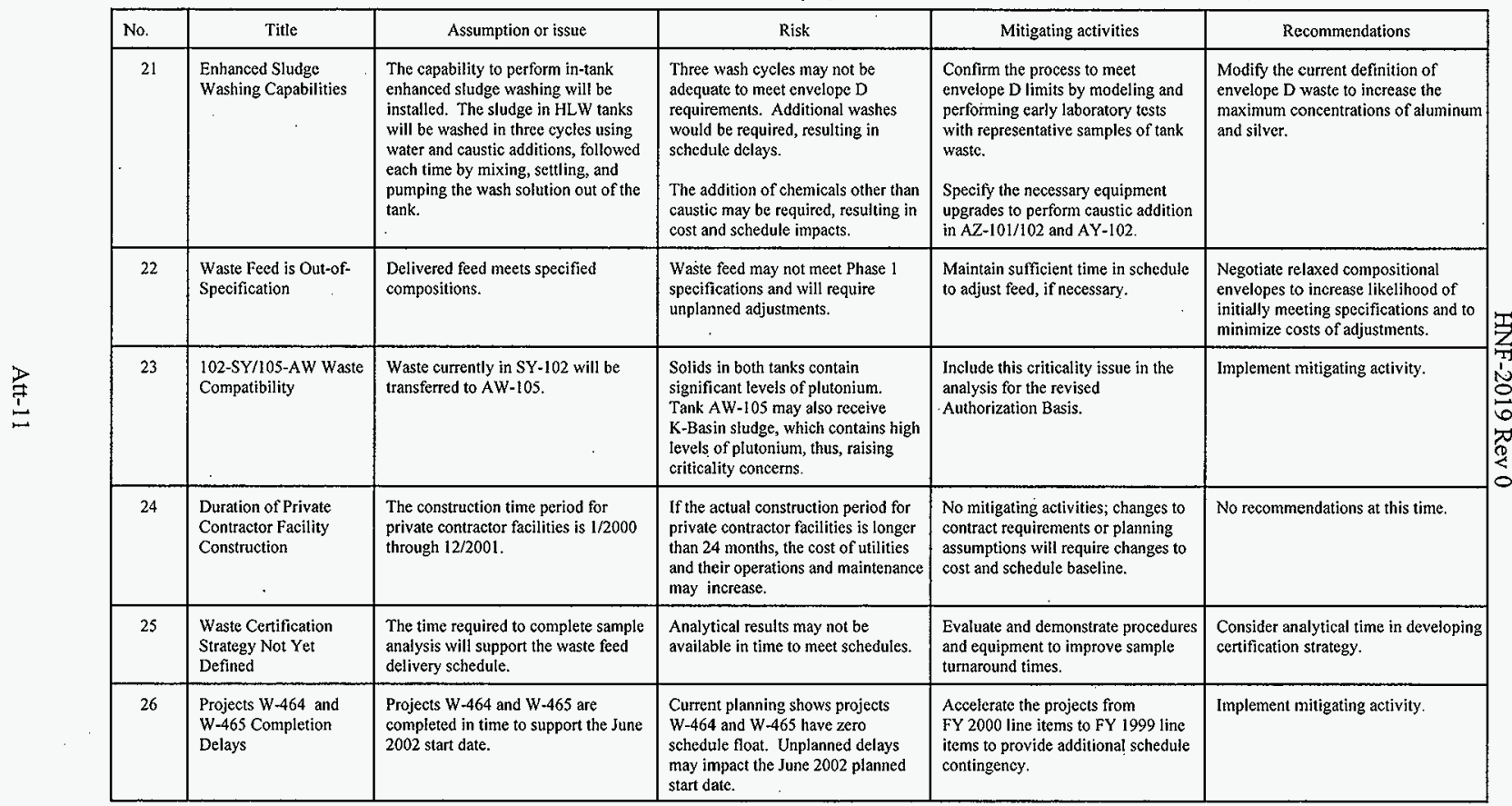


Tank Waste Retrieval System Retrieval and Disposal Mission Critical Risk List (9 Sheets)

\begin{tabular}{|c|c|c|c|c|c|}
\hline No. & Title & Assumption or issue & Risk, & Mitigating activities & Recommendations \\
\hline 27 & $\begin{array}{l}\text { Plugged Transfer Lines } \\
\text {. }\end{array}$ & $\begin{array}{l}\text { Waste feed delivery to the private } \\
\text { contractors will be made in a timely } \\
\text { manner so that there are no unplanned } \\
\text { shutdowns of the private contractor's } \\
\text { facilities. }\end{array}$ & $\begin{array}{l}\text { Transfer lines may become plugged, } \\
\text { resulting in delays of waste feed } \\
\text { delivery to the private contractors. }\end{array}$ & $\begin{array}{l}\text { Conduct pre-transfer analysis to } \\
\text { confirm that waste will not plug lines } \\
\text { during transfer. } \\
\text { Develop methods for unplugging } \\
\text { lines. } \\
\text { Identify alternate transfer routes to } \\
\text { bypass plugged line. } \\
\text { Identify alternate feed tanks. }\end{array}$ & Implement mitigating activities. \\
\hline 28 & $\begin{array}{l}\text { Failure of Mixer or } \\
\text { Transfer Pumps }\end{array}$ & $\begin{array}{l}\text { The presence of abandoned equipment } \\
\text { in a waste feed tank will not } \\
\text { compromise the capability of the } \\
\text { mixer and transfer pumps. }\end{array}$ & $\begin{array}{l}\text { Abandoned equipment in the feed } \\
\text { tanks could be sucked into a mixer } \\
\text { pump or transfer pump, causing the } \\
\text { pump to fail and delaying waste feed } \\
\text { delivery. }\end{array}$ & $\begin{array}{l}\text { Develop pumps that are robust in } \\
\text { design and performance. } \\
\text { Ensure spare parts and pumps are } \\
\text { readily available. } \\
\text { Train personnel to change out failed } \\
\text { pumps/parts quickly. }\end{array}$ & Implement mitigating activities. \\
\hline 29 & $\begin{array}{l}\text { Insufficient Regulatory } \\
\text { Agency Staffing }\end{array}$ & $\begin{array}{l}\text { Regulatory agencies will be } \\
\text { adequately funded by DOE to support } \\
\text { review and approval of necessary } \\
\text { permit applications. (EA-15) }\end{array}$ & $\begin{array}{l}\text { Lack of resources for key regulators } \\
\text { will cause delays in critical path } \\
\text { activities because of lengthy permit } \\
\text { approval cycle. }\end{array}$ & $\begin{array}{l}\text { No mitigating activity; changes to } \\
\text { contract requirements or planning } \\
\text { assumptions will require changes to } \\
\text { cost and schedule baseline. }\end{array}$ & $\begin{array}{l}\text { RL should provide sufficient budget } \\
\text { for regulatory support activities. }\end{array}$ \\
\hline 30 & Insufficient Spare Parts & $\begin{array}{l}\text { Sufficient funding has been identified } \\
\text { in the multi-year work plan and/or } \\
\text { technical basis review (either Work } \\
\text { Breakdown Structure Level } 7 \text { or } 8 \text { ) for } \\
\text { the spare parts required to support } \\
\text { Phase 1. }\end{array}$ & $\begin{array}{l}\text { Results of the RAM studies may } \\
\text { conclude that significantly more } \\
\text { spare parts (e.g., replacement } \\
\text { pumps) are required. }\end{array}$ & $\begin{array}{l}\text { Complete RAM analyses (in } \\
\text { progress). Revise out-year funding } \\
\text { requirements as necessary to } \\
\text { incorporate recommendations from } \\
\text { the study. }\end{array}$ & Implement mitigating activities. \\
\hline 31 & $\begin{array}{l}\text { Waste Feed } \\
\text { Specification Disputes }\end{array}$ & $\begin{array}{l}\text { Results of waste feed sample analyses } \\
\text { by the private contractors and PHMC } \\
\text { will be agreed to all parties. }\end{array}$ & $\begin{array}{l}\text { Waste feed, which the PHMC } \\
\text { analysis shows as being in } \\
\text { specification, may be unacceptable } \\
\text { to the privatc contractors based on } \\
\text { the results of their analyses, thereby } \\
\text { delaying waste feed delivery to the } \\
\text { private contractors. }\end{array}$ & $\begin{array}{l}\text { Incorporate contractual language that } \\
\text { will minimize delays of waste feed } \\
\text { delivery based on disputed results of } \\
\text { waste feed sample analysis. }\end{array}$ & $\begin{array}{l}\text { Implement mitigating activity as part } \\
\text { of DOE's contract negotiations with } \\
\text { the private contractors. }\end{array}$ \\
\hline
\end{tabular}


Tank Waste Retrieval System Retrieval and Disposal Mission Critical Risk List (9 Sheets)

\begin{tabular}{|c|c|c|c|c|c|}
\hline No. & Title & Assumption or issue & Risk & Mitigating activities & Recommendations \\
\hline 32 & $222 S$ Laboratories & $\begin{array}{l}\text { The base loading for } 222 S \text { Laboratory } \\
\text { and WSCF operations will support the } \\
\text { required sampling }\end{array}$ & $\begin{array}{l}\text { As the number of waste samples } \\
\text { from the PHMC decreases, the } \\
\text { number of qualified } 222 \mathrm{~S} \text { and WSCF } \\
\text { laboratory staff will be reduced. } \\
\text { These reductions will potentially } \\
\text { increase both the turnaround time } \\
\text { and the cost of analytical services. }\end{array}$ & $\begin{array}{l}\text { Investigate ways of deferring PHMC } \\
\text { waste analyses, starting in FY } 1999 \text {, } \\
\text { to level load work in the } 2225 \text { and } \\
\text { wSCF laboratories. The risk in this } \\
\text { mitigating action is that waste } \\
\text { characterization data of feed tanks } \\
\text { will not be available to the PHMC as } \\
\text { soon as currently planned and } \\
\text { provides only a short-term fix } \\
\text { through } 2000 \text {. } \\
\text { Have RL investigate including } \\
\text { contractual requirements on the } \\
\text { Private Contractors to use } 222 S \text { and } \\
\text { WSCF capabilities to meet the PCS } \\
\text { analytical needs, based on required } \\
\text { analyses and test methods for } \\
\text { supporting the vitrification process } \\
\text { and an estimate of the frequency and } \\
\text { turnaround times required by the } \\
\text { private contractors. RL should also } \\
\text { investigate other business } \\
\text { opportunities that use the } 222 S \text { and } \\
\text { WSCF laboratory services. This is } \\
\text { particularly important atter the } \\
\text { year } 2000 \text {. }\end{array}$ & $\begin{array}{l}\mathrm{RL} \text {. should include } 222 \mathrm{~S} \text { and WSCF } \\
\text { analytical services as part of the } \\
\text { upcoming contract negotiations with } \\
\text { the private contractors. }\end{array}$ \\
\hline
\end{tabular}

A Public Law 101-510, National Defense Authorization Act for Fiseal Year 1991, Section 3137, "Wyden Bill," November 5, 1990.

${ }^{13}$ Kirkbride, R. A., G. K. Allen, P. J. Certa, A. F. Manuel, R. M. Orme, L. W. Sheiton, E. J. Slaathaug, R. S. Wittman, G. T. MacLean, and D. L. Penwell (SESC), 1997, Tank Waste Remediation System Operation and Utilization Plan, HNF-SD-WM-SP-012, Rev. 0, Volumes I and II, prepared by Numatec Hanford Corporation for Fluor Daniel Hanford, Inc., Richland, Washington.

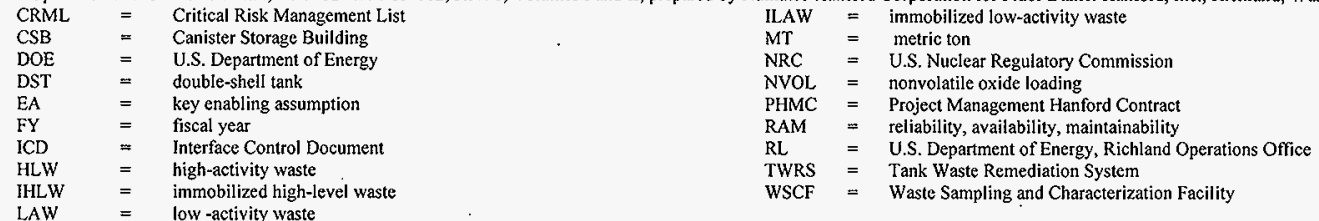


HNF-2019 Rev 0

This page intentionally left blank.

Att-14 


\section{DISTRIBUTION SHEET}

\begin{tabular}{|c|c|c|c|c|c|}
\hline \multirow{2}{*}{$\begin{array}{l}\text { To } \\
\text { Document Control Services }\end{array}$} & \multirow{2}{*}{$\begin{array}{l}\text { From } \\
\text { TWRS Config }\end{array}$} & & & \multicolumn{2}{|c|}{ Page 1 of 1} \\
\hline & & tion Mana & nent & \multicolumn{2}{|c|}{ Date January 3, 1998} \\
\hline \multirow{2}{*}{\multicolumn{4}{|c|}{$\begin{array}{l}\text { Project Title/Work Order } \\
\text { Tank Waste Remediation Systems (HNF-2019) }\end{array}$}} & \multirow{2}{*}{\multicolumn{2}{|c|}{$\begin{array}{l}\text { EOT No. } 622750 \\
\text { ECN No. }\end{array}$}} \\
\hline & & & & & \\
\hline Name & MSIN & $\begin{array}{l}\text { Text } \\
\text { With All } \\
\text { Attach. }\end{array}$ & $\begin{array}{l}\text { Text } \\
\text { Only }\end{array}$ & $\begin{array}{l}\text { Attach./ } \\
\text { Appendix } \\
\text { Only }\end{array}$ & $\begin{array}{c}\text { EDT/ECN } \\
\text { Only }\end{array}$ \\
\hline
\end{tabular}

J.N. Alibert

H.L. Boston

M.P. Delozier

M. D. Ebben

0. A. Halvorson

J.0. Honeyman

K.N. Jordan

R.A. Kirkbride

S.C. KT imper

M.R. Lewis

D.M. McDanie]

R.J. Murkowski

M.A. Payne

M.L. Peterman

R.W. Powe 11

R.E, Raymond

S.H. Rifaey

B. Root

P.S. Schaus

S.E. Seeman

S.J. Simon

W.R. Swita

R.L. Treat

J.M. Vann

J.H. Wicks Jr

R.D. Wojtasek
S2-48

G3-21

R2-58

H7 -07

G3-21

G3-21

G3-21

H5-27

H6- 25

H5- 03

H7 -06

H6-37

R2-58

H7- 06

H5- 03

R2-38

R1-56

G3-21

H5- 03

H6-35

H7 -06

H5-03

H5- 03

H6-37

H7 -07

G3-21 $x$

2 copies

$x$

$x$

$x$

$x$

$x$

$x$

$x$

$x$

3 copies

3 copies

2 copies

$X$

$x$

$x$

$x$

$x$

$x$

$x$

$x$

$x$

2 copies

$x$

$x$

3 copies

Central Files

B]-07

$x$ 